UNIVERSIDADE DE SÃO PAULO

ESCOLA DE ENFERMAGEM

FÁTIMA APARECIDA COTRIM SOARES

INFLUÊNCIA DA CAPACITAÇÃO EM BIOÉTICA NA PERCEPÇÃO DOS PROFISSIONAIS PARA OS PROBLEMAS ÉTICOS NA ATENÇÃO BÁSICA

São Paulo

2010 


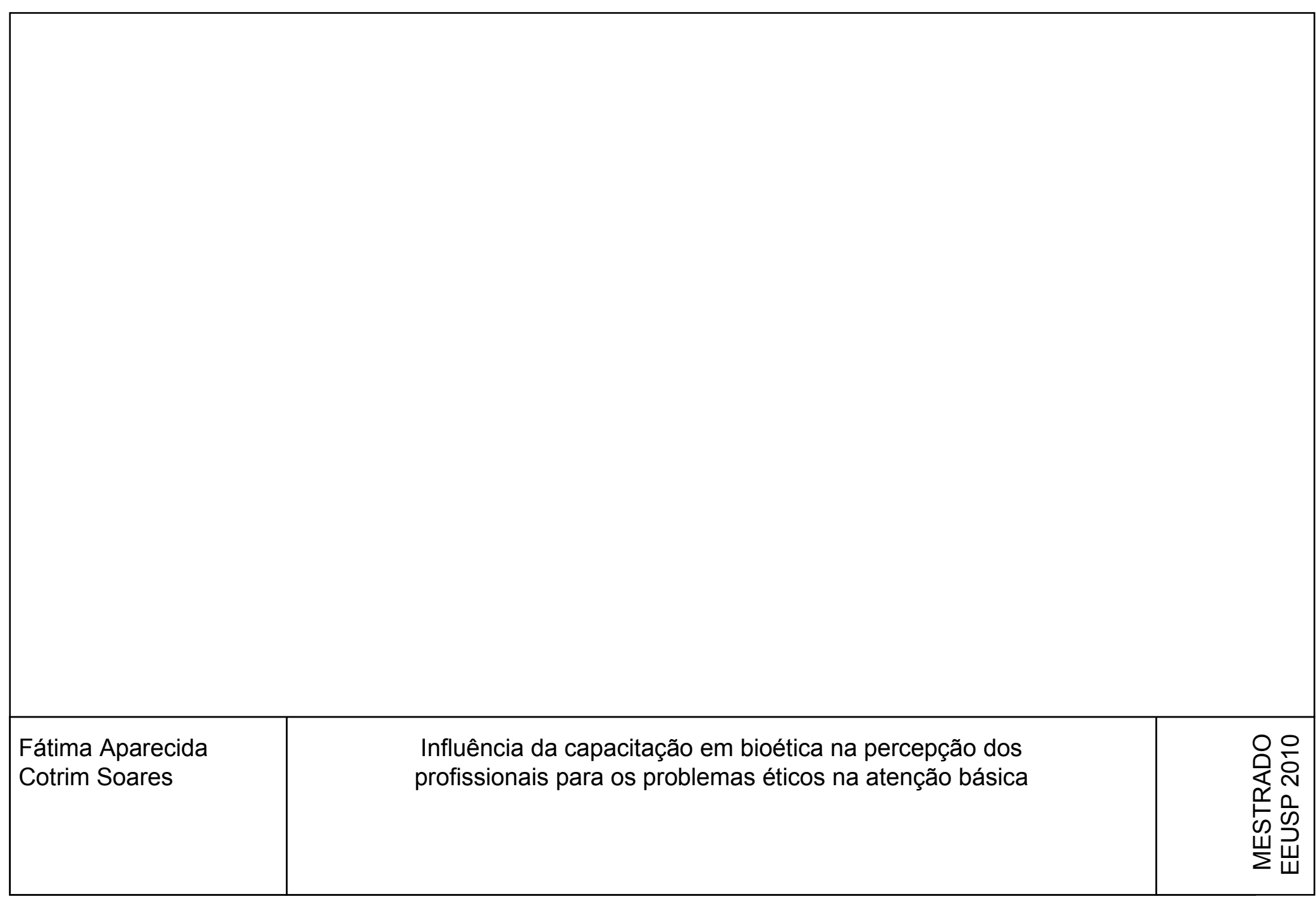


FÁTIMA APARECIDA COTRIM SOARES

\section{INFLUÊNCIA DA CAPACITAÇÃO EM BIOÉTICA NA PERCEPÇÃO DOS PROFISSIONAIS PARA OS PROBLEMAS ÉTICOS NA ATENÇÃO BÁSICA}

Tese apresentada à Escola de Enfermagem da Universidade de São Paulo para obtenção do título de mestre em Ciências.

Área de concentração: Cuidado em Saúde

Orientadora: Prof. ${ }^{a}$ Dr. ${ }^{a}$ Elma Lourdes

Campos Pavone Zoboli 
AUTORIZO A REPRODUÇÃO TOTAL OU PARCIAL DESTE TRABALHO, POR QUALQUER MEIO CONVENCIONAL OU ELETRÔNICO, PARA FINS DE ESTUDO E PESQUISA, DESDE QUE CITADA A FONTE.

Assinatura:

Data

Catalogação na Publicação (CIP)

Biblioteca "Wanda de Aguiar Horta"

Escola de Enfermagem da Universidade de São Paulo

Soares, Fátima Aparecida Cotrim.

Influência da capacitação em bioética na percepção dos profissionais para os problemas éticos na atenção básica / Fátima Aparecida Cotrim Soares - São Paulo, 2010.

Dissertação (Mestrado) - Escola de Enfermagem da Universidade de São Paulo.

Orientadora: Prof ${ }^{\mathrm{a}} \mathrm{Dr}^{\mathrm{a}}$ Elma Lourdes Campos Pavone Zoboli

1.Ação Educativa, 2. Bioética Clínica, 3.Deliberação Moral. 
NOME: Fátima Aparecida Cotrim Soares

TITULO: Influência da capacitação em bioética na percepção dos profissionais para os problemas éticos na atenção básica.

Dissertação apresentada à Escola de Enfermagem da Universidade de São Paulo, para obtenção do título de Mestre em Ciências.

Aprovado em :

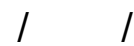

\section{Banca Examinadora}

Prof. Dr. Instituição:

Julgamento: Assinatura:

Prof. Dr. Instituição:

Julgamento: Assinatura:

Prof. Dr. Instituição:

Julgamento: Assinatura: 


\section{Agradecimentos}

A Deus, por me proporcionar força e coragem para seguir em frente nesta jornada.

A minha mãe, por manter a ordem local, proporcionando uma base sólida para esta embrenhada.

Ao meu amado esposo Erik,, por trilhar ao meu lado sempre acreditando em mim, mesmo nos momentos em que me dava por vencida.

A meu filho, Enrico, amor de minha vida, obrigado por ser tão compreensivo e bondoso, mil desculpas pelos: agora não, depois, fala com seu pai, não vai dar, não pode, etc...

A minha amiga Silvia, por agüentar meu mal humor e minha chatice sem reclamar, obrigado por estar sempre presente.

A minha amiga Virginia, obrigado pelo apoio e força.

Aos meus amigos do ARMI, pelo companheirismo e força. em todos os momentos.

Ao Departamento de Atenção a Saúde de Santo André, pelo apoio e pela confiança.

Aos funcionários da EEUSP, pela gentileza, paciência, atenção e eficiência no atendimento.

Em especial à Profa Dra Elma Lourdes Campos Pavone Zoboli , minha orientadora, pela paciência, confiança e por propiciado o encontro com um oceano de conhecimentos e práticas até então desconhecido. Muito, muito obrigado por tudo e você sabe o que eu quero dizer, além de orientadora excepcional você é um ser humano ímpar. 
Soares FAC. Influência da capacitação em bioética na percepção dos profissionais para os problemas éticos na atenção básica [dissertação]. São Paulo: Escola de Enfermagem Universidade São Paulo: 2010.

\section{Resumo}

Pesquisa qualitativa, que se caracterizou como um estudo do tipo antes e depois. Teve como objetivo principal analisar o impacto de uma ação educativa em bioética clínica e deliberação moral aplicadas à atenção básica, com vistas a identificar se a percepção de problemas éticos se modificaria e se esta ação traria contribuições com aportes para lidar com as questões éticas na prática. A ação educativa foi desenvolvida com enfermeiros e médicos da Estratégia Saúde da Família, Santo André, SP, e calcou-se no enfoque problematizador e na bioética deliberativa, para apresentar o itinerário da deliberação como subsídio para o manejo de problemas éticos. Para avaliar a mudança na percepção de problemas éticos, foi aplicado um instrumento para inventariar tais situações, antes, depois e no meio da intervenção. Para avaliar a utilidade da ação educativa, foram feitas perguntas abertas, cujas respostas foram tratadas com análise de conteúdo. Houve mobilização positiva da sensibilidade ética dos participantes. Eles avaliaram a deliberação como um instrumental adequado para lidar com as questões éticas que vivem. A problematização mostrou-se efetiva como estratégia educativa na formação contínua em bioética deliberativa.

Palavras chaves: Ação Educativa, Bioética Clínica, Deliberação Moral. 
Soares FAC. Influence of training in bioethics to professionals in the perception of ethical problems in primary care [dissertation]. São Paulo: Nursing School at the University of São Paulo: 2010.

\begin{abstract}
Qualitative research, which was characterized with a kind of study before and after. The main objective was analyzing the impact of an educational intervention in clinical bioethics and moral decision applied to primary care, aiming to identify the perceived ethical problems would change and if this action would bring with subsidiary contributions to deal with ethical issues in practice. The educational activity was developed with nurses and medical doctors from the Family Health Strategy, Santo André, SP. The educational activity trod on the problem-posing approach and deliberative bioethics, to present the itinerary of the determination as to subsidize the management of ethical issues. To evaluate the usefulness of educational activities open-ended questions were made whose answers were dealt with content analysis. There was positive mobilization of ethical sensitivity of the participants. They evaluated the decision as an appropriate instrument to deal with ethical issues which they live. The problem-posing education strategy showed effective in continuous training in deliberative bioethics.
\end{abstract}

Keywords: Deliberative Action, Clinical Bioethics, Moral Deliberation. 


\section{LISTA DE FIGURAS}

Figura 1 Método do Arco

Figura 2 Representação esquemática do estudo

Figura 3 Aprendizagem em um curso de deliberação moral

Figura 4 Capacitação em bioética

Figura 5 Influência do curso sobre bioética e deliberação moral na prática do trabalho diário 


\section{LISTA DE TABELAS}

Tabela 1 - Perfil demográfico da amostra de médicos - Santo André - 201065

Tabela 2 - Perfil demográfico da amostra - enfermeiros - Santo André - 201066

Tabela 3 - Identificação de problemas éticos pela amostra, de acordo com o momento de aplicação $\left(1^{\circ}, 2^{\circ}\right.$ e $\left.3^{\circ}\right)$ do IPE-APS - Santo André - 2010

Tabela 4 - Distribuição da frequência da ocorrência de problemas éticos na amostra segundo o momento $\left(1^{\circ}, 2^{\circ}\right.$ e $\left.3^{\circ}\right)$ de aplicação do IPE-APS - Santo André - 2010 


\section{LISTA DE SIGLAS}

MS

Ministério da Saúde

SUS

Sistema Único de Saúde

ESF

Estratégia de Saúde da Família

IPE - APS

Inventário de Problemas Éticos na Atenção Básica

DAS

Departamento de Atenção à Saúde

PMSA

Prefeitura do Município de Santo André 


\section{SUMÁRIO}

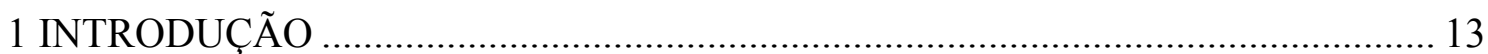

1.1 FORMAÇÃO EM ÉTICA E BIOÉTICA ……………………………………....... 18

1.2 O ENFOQUE PROBLEMATIZADOR NA FORMAÇÃO DE

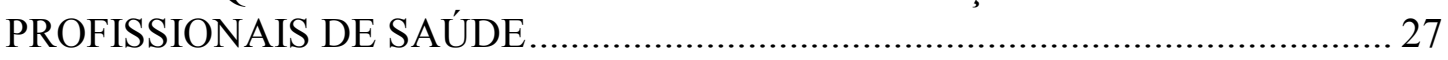

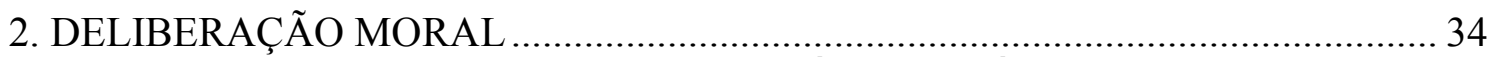

2.1 O PROBLEMATISMO MORAL NA PRÁTICA CLÍNICA …………………........ 45

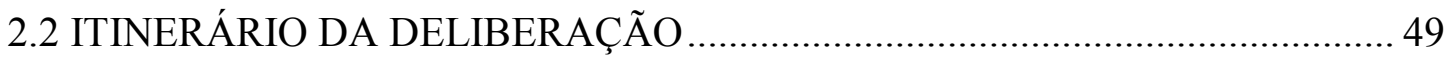

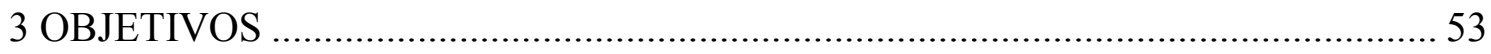

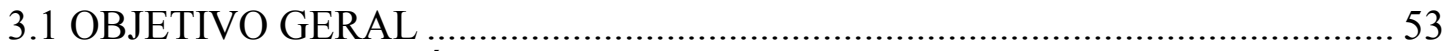

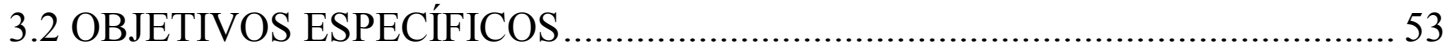

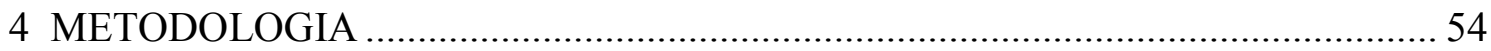

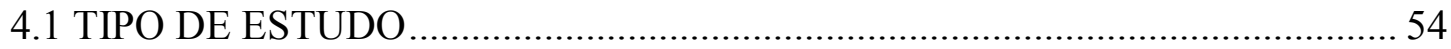

4.2 A INTERVENÇÃO PEDAGÓGICA: UMA AÇÃO EDUCATIVA EM BIOÉTICA CLÍNICA E DELIBERAÇÃO MORAL APLICADAS À ATENÇÃO

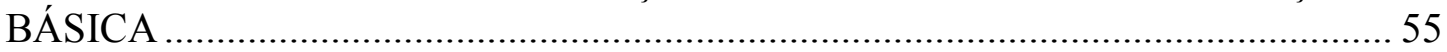

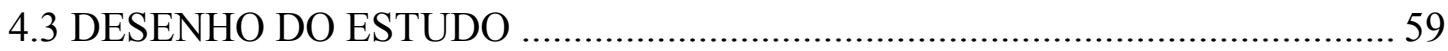

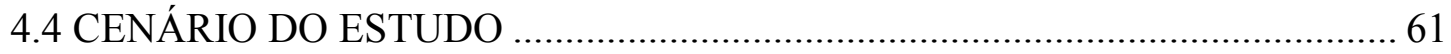

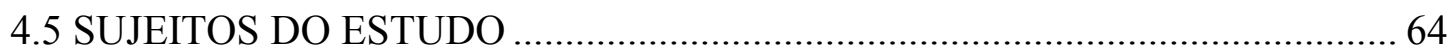

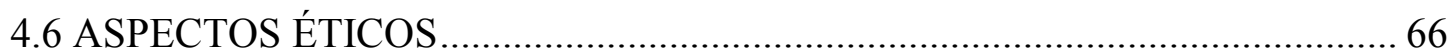

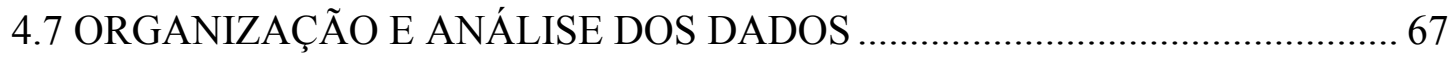

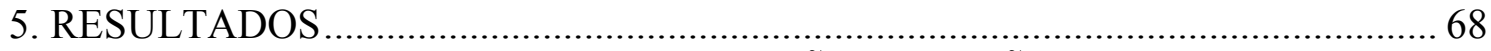

5.1 PROCEDIMENTOS PARA REALIZAÇÃO DA AÇÃO EDUCATIVA ………. 68

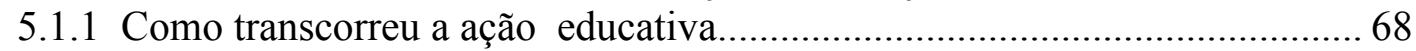

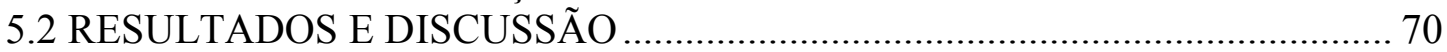

5.2.1. Resultados da aplicação do IPE-APS........................................................... 70

5.3. A OPINIÃO DOS PARTICIPANTES QUANTO A UTILIDADE E

ADEQUAÇÃO DA PROPOSTA PARA O SEU TRABALHO NA AB ..................... 77

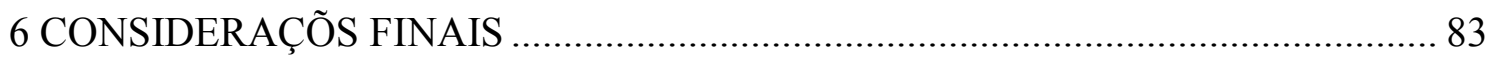

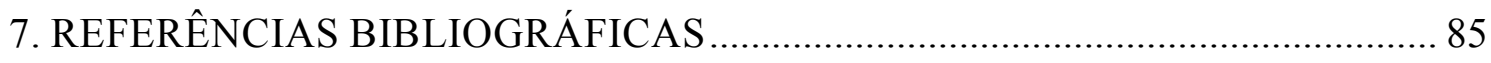

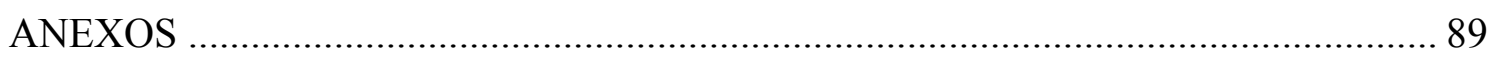




\section{INTRODUÇÃO}

A atenção básica e a especificidade de suas questões éticas são compreendidas como um conjunto de ações que exige dos profissionais de saúde um olhar ampliado, pois se depara com peculiaridades que decorrem da assistência prestada com um caráter geral, que é, de fato, trabalhar com um quadro complexo, de grande magnitude e diversidade de situações socioeconômicas da população assistida.

Além disso, propõe-se a atenção básica como um nível de atenção, no Sistema Único de Saúde (SUS), acessível, integrado, preventivo e promotor de saúde, a ser concretizado por meio do trabalho em equipe com olhar aberto para a integralidade do ser humano e não apenas focado na enfermidade.

Documentação oficial do Ministério da Saúde (Brasil, 2007), define a Atenção Básica como:

Conjunto de ações de saúde, no âmbito individual e
coletivo, que abrangem a promoção e a proteção da
saúde, a prevenção de agravos, o diagnóstico, o
tratamento, a reabilitação e a manutenção da saúde. É
desenvolvida por meio do exercício de práticas gerenciais
e sanitárias democráticas e participativas, sob forma de
trabalho em equipe, dirigidas a populações de territórios
bem delimitados, pelas quais assume a responsabilidade
sanitária, considerando a dinamicidade existente no
território em que vivem essas populações. Utiliza
tecnologias de elevada complexidade e baixa densidade,
que devem resolver os problemas de saúde de maior
frequencia e relevância em seu território. É o contato
preferencial dos usuários com os sistemas de saúde.
Orienta-se pelos princípios da universalidade, da
acessibilidade e da coordenação do cuidado, do vínculo e
continuidade, da integralidade, da responsabilização, da
humanização, da equidade e da participação social...
considera o sujeito em sua singularidade, na
complexidade, na integralidade e na inserção sócio-
cultural e busca a promoção de sua saúde, a prevenção e
tratamento de doenças e a redução de danos ou de
sofrimentos que possam comprometer suas possibilidades
de viver de modo saudável.

Nos fundamentos da Atenção Básica, o MS (2007), inclui: possibilitar, com base na equidade e como porta de entrada preferencial do sistema de saúde, o acesso universal e contínuo a serviços de saúde de qualidade e resolutivos; efetivar a integralidade da assistência em seus vários aspectos; 
desenvolver relações de vínculos e responsabilização entre as equipes e a população adscrita; valorizar os profissionais de saúde; realizar avaliação e acompanhamento sistemático dos resultados alcançados; estimular a participação popular e controle social.

Para desenvolver relações de vínculos e corresponsabillização no cuidado na atenção básica, é essencial que ocorra a copresença e a interrelação dos saberes instrumentais e saberes práticos, como proposto por Ayres (2007, p. 53):

\begin{abstract}
Em geral, os profissionais de saúde estão preocupados com boas práticas de saúde por meio das técnicas, ou seja, com o alcance de bons resultados técnicos. Obter bons resultados é essencial, mas é necessário ultrapassar a busca do êxito técnico, e junto imprimir atitudes compreensivas no processo de cuidar, caminhando para a construção de novos entendimentos das situações que as famílias enfrentam. Implica dar mais vazão a uma totalidade compreensiva que busca dar sentido às demandas levadas por famílias e crianças aos profissionais e serviços de saúde. O conceito de êxito técnico está estreitamente ligado ao conceito de sucesso prático. Esse se volta para o valor que a ação de saúde tem para sujeitos e populações, engloba um conjunto de implicações simbólicas, relacionais e materiais das intervenções e recomendações de saúde na vida cotidiana dos sujeitos. É um conceito que expressa o que os meios e fins das ações de saúde têm, face aos valores e interesses que sujeitos e populações conferem ao adoecimento e à atenção à saúde.
\end{abstract}

O cuidado se constrói na relação intersubjetiva, presumidamente, deveria basear-se no respeito mútuo e incluir, nas queixas clínicas, os fatos narrados pelos usuários, as emoções, os sentimentos para ultrapassar o usual levantamento de sinais, sintomas e diagnósticos laboratoriais. Entretanto, perpassa esta relação a questão da degeneração dos vínculos, com omissão ou negação dos direitos dos trabalhadores e usuários; precarização das condições e dos processos de trabalho; comprometimento da resolubilidade e qualidade do cuidado prestado (Zoboli, 2009).

Assim, ainda que tanto a atenção hospitalar como a básica podem, e precisam, ser humanizadas, cada qual terá sua peculiaridade para isto. O olhar ético e clínico, que são bons e próprios para a atenção hospitalar, não obrigatoriamente o serão para a Atenção Básica (Zoboli, 2009, p. 196). 
Por considerar o sujeito em sua singularidade, integralidade e inserção sociocultural, a atenção básica lida com fatos e valores distintos, e, por vezes, com conflitos de maior amplitude e complexidade, ainda que de menor dramaticidade quando comparada com o âmbito hospitalar. São conflitos morais e humanos típicos do cotidiano da atenção à saúde que podem passar despercebidos por conta de sua sutileza (Zoboli, 2003).

Segundo Silva (2006), na atenção básica, os problemas éticos apontados pelos profissionais de saúde são, de maneira geral, preocupações do cotidiano da assistência à saúde e não situações críticas e dramáticas que requerem soluções imediatas, como as enfrentadas no contexto do hospital.

Os conflitos morais na atenção básica, segundo as vozes de enfermeiros e médicos, mostram que o bom andamento da relação clínica está sob ameaça, em vários aspectos. Há dificuldade em estabelecer os limites da relação profissional - usuário, não se sabendo se, como e quanto se interfere no estilo de vida das famílias ou usuários. O desrespeito é comum.

Os profissionais dizem que não conseguem informar o paciente de maneira a pactuar sua adesão. A falta de companherismo e o desrespeito também entre os profissionais de saúde aparecem como problemas éticos, especialmente quando é difícil delimitar os papéis e responsabilidades de cada um (Zoboli, 2006).

As peculiaridades decorrentes do tipo de assistência prestada e do leque de serviços oferecidos na atenção básica acabam por se refletir nas relações entre os profissionais de saúde e os usuários, e por fim nas questões éticas que emergem neste nível do Sistema de Saúde.

Com a Reforma Sanitária e a instauração do SUS, surge uma prática sanitária inovadora, baseada em um processo de mudança que exige dos profissionais, gestores e usuários transformações atitudinais e culturais. Ou seja, a efetiva implementação do SUS requer uma reviravolta ética. Para fazer frente ao desafio da concretização de uma política pública de saúde universal, equitativa e integral, faz-se necessário lidar com as questões de ordem ética vivenciadas nos serviços de saúde, especialmente na atenção básica, porta de entrada preferencial do SUS. 
$\mathrm{Na}$ atenção básica, encontramos uma série de ações que são realizadas. Estas têm de ser organizadas pela Estratégia da Saúde da Família (ESF). Neste cenário, a questão ética, à interrelação entre usuários e profissionais de saúde, é mais próxima, contínua e intensa.

A ESF amplia a concepção da atenção básica, avançando na direção de um sistema de saúde integrado que converge para a qualidade de vida das pessoas e de seu meio ambiente. Assim, se a construção do SUS implica uma reviravolta ética, reorganizada na atenção básica pela ESF, alarga e aprofunda o trajeto desse giro, pois sua efetivação não se resume a uma nova configuração da equipe técnico-assistencial, mas a um novo processo de trabalho por uma prática ética, humana, vinculada ao exercício da cidadania (Zoboli, 2003).

A ética nas relações profissionais se constrói por intermédio de responsabilidade, compromisso com o trabalho, com o outro, respeito $\mathrm{e}$ afetividade às pessoas. Para tanto, a ética requer do profissional formação em atitudes, valores e habilidades.

O processo de trabalho na atenção básica nos traz o cuidado do usuário no universo em que se encontra inserido. Isto implica a participação, compreensão, mudança de atitude dos profissionais de saúde, com apelos para a escuta e o diálogo. Ou seja, a efetivação da ESF requer novos saberes e aguçada sensibilidade humana para uma nova ética, que leve à especificidade da atenção básica. Evidencia-se a necessidade de competência moral, ética, diferenciada para lidar com os problemas éticos na atenção básica.

A excelência ética não é mera questão de imaginação, bons desejos, boa vontade, bom senso e retas decisões, mas requer a mesma árdua e paciente aprendizagem que qualquer outra habilidade humana (Gracia, 1998a).

As profissões de saúde distinguem-se por sua responsabilidade ética, entretanto, frente à novidade e complexidade dos problemas éticos atuais, tem sido insuficiente recorrer aos códigos de ética profissional. É necessário incorporar a formação contínua dos profissionais para uma nova abordagem da ética, que fomente a aquisição de hábitos deliberativos e considere o pluralismo moral, as possibilidades da biotecnologia e as transformações na 
saúde e assistência. Na clínica, passamos da imposição à autogestão; da beneficência paternalista dos profissionais, à autonomia dos usuários dos serviços de saúde. Na atenção básica, o usuário é, todavia, mais autônomo e a decisão de tratar-se ou não dependerá muito das relações de vínculo e sentido, ou seja, da ética das relações (Gracia, 1998a).

As questões da relação, dos vínculos e da valorização do profissional, com investimento em sua formação continuada, estiveram em pauta neste estudo cuja proposta buscou identificar se os problemas éticos na atenção básica são percebidos pelos profissionais de saúde e se sua participação em um curso de capacitação em bioética clínica e deliberação moral modificaria a percepção que têm acerca destas questões em sua prática. No caso de isso ser verdadeiro, pergunta-se: em que sentido dá-se esta modificação?

Assim, o estudo incluiu uma capacitação em bioética para profissionais de saúde que atuam na atenção básica do SUS, especialmente nos enfermeiros e médicos da ESF de Santo André.

A capacitação considerou as peculiaridades da prática profissional e da assistência na atenção básica como parte constituinte e instituinte do SUS e das políticas públicas para a humanização da assistência prestada no Sistema. Com noções de bioética, apresentou e propôs o método deliberativo como forma de: (a) desenvolver e integrar uma base de conhecimentos e habilidades em bioética por meio de um processo de autoeducação, quase autoanálise, que propiciasse a transformação da prática profissional a partir da incorporação de valores que resultassem em mudanças atitudinais; (b) interpretar dados e estabelecer conexões de sentido que permitissem identificar e abordar os conflitos éticos que surgem no trabalho diário, com vistas a melhorar a qualidade e a humanização da assistência (c) propiciar, a partir da situação clínica, a ponderação e inclusão dos valores e aspectos contextuais que concorrem para a situação vivida pelo usuário, sua família e a equipe de saúde, melhorando a compreensão das vivências e experiências; (d) levar os profissionais a mudanças atitudinais, num compromisso responsável com a 
excelência moral e técnica de sua prática profissional e da assistência que prestam. $^{1}$

O propósito do curso, como parte do estudo, foi oferecer um método prático para tomada de decisões éticas na resolução de casos clínicos através do uso do itinerário da deliberação moral, que, a partir da situação clínica, realiza a elucidação dos problemas éticos para posterior realização de valores. Para isso, utiliza-se de um método próprio, ou seja, de um itinerário de passos e operações que foram objeto da capacitação aplicada no estudo.

Esta pesquisa contribuiu para adensamento da interface entre bioética e a atenção básica, tema ainda pouco estudado na saúde coletiva e na própria bioética enquanto disciplina acadêmica e campo de produção de conhecimento.

\subsection{FORMAÇÃO EM ÉTICA E BIOÉTICA}

O ensino em ética é um tema difícil e complexo. Quando se trata de ensinar disciplinas compostas fundamentalmente de ações objetivas, como eletrônica, geometria e até mesmo os procedimentos da medicina, asseguramos que os conteúdos a serem transmitidos são conhecimentos. Trabalham-se, assim, mais os conhecimentos e as habilidades técnicas, do que as humana (Gracia, 1998).

O problema do ensino de ética é que este não está ligado apenas a conhecimentos e habilidades, mas inclui as atitudes e a forja do caráter das pessoas.

O significado de ética vem do grego ethos: maneira de ser, caráter, o mesmo que mos: em latim. A primeira questão que surge é se estas dimensões da personalidade humana podem ser ensinadas, especialmente na formação profissional inicial e continuada.

\footnotetext{
${ }^{1}$ A proposta de capacitação foi elaborada pela orientadora deste projeto de mestrado durante sua estada de pós-doutorado entre janeiro e junho de 2009, na Universidade Complutense de Madrid.
} 
Para o discernimento do modo mais eticamente responsável de viver e agir, não basta o conhecimento técnico ou teórico de diferentes perspectivas da filosofia moral; é preciso estabelecer relações, justificar, analisar, criar compreender e transformar o mundo a fim de promover uma existência digna. Para isso, é indispensável ter claro que critérios ou princípios estão sendo usados nas explicações, nos argumentos e nas justificativas das ações e dos juízos morais. Há de se ter em mente, sempre as questões norteadoras: Como devo agir? Por que devo agir de tal modo? Que vida eu quero viver? Que vida quero para os demais? Para o planeta?(Gracia,1998).

Abordar o problema da formação ética e dos valores morais significa retomar os referenciais políticos, epistemológicos e pedagógicos da educação, repensar os processos de ensinar e aprender, uma vez que o estudo da ética não pode ser abordado simplesmente como conteúdo a ser estudado, mas como fundamento de todas as atividades da prática do profissional. (Kuiava, Sangalli, 2008).

$\mathrm{Na}$ enfermagem, historicamente, o ensino da ética tem contribuído para a disseminação de uma "ética alienada", ancorada muito mais na coerção externa e na obediência a uma autoridade do que na reflexão autônoma dos profissionais a partir de valores e princípios (Germano 1993).

O tema do ensino da ética é tão antigo como a própria cultura ocidental. Na verdade, é uma questão existente desde os tempos de Sócrates. Para o pai da ética como disciplina filosófica, o problema era precisamente se poderia ser ensinada. Apostava que sim, mas com a condição de que se evitassem certos vícios que levariam todos a persistirem em aspectos incorretos. O filósofo era conhecido em Atenas por seu hábito de formular perguntas difíceis, interrogando a todos, que tentavam respondê-las. Colocava em xeque suas afirmações maeuticamente, ou seja, usava produzir uma modificação interna e ajudar os interlocutores a se conhecer melhor. Com isso, criava, na prática, uma pedagogia para o ensino da ética (Gracia, 1998).

O propósito de tal método consistia em mostrar aos interlocutores como as idéias por eles defendidas entravam em contradição. O filósofo defendia que a única maneira de alcançar a verdade era pelo esforço pessoal, interno, de rever e questionar idéias preconcebidas. A tarefa era levar o interlocutor a 
encontrar a verdade pelo intermédio do debate, não só com o interlocutor, mas consigo mesmo, de suas próprias idéias (Gottschalk, 2007).

O mais comum nos processos de formação em ética é que partam da concepção do discente como um receptáculo do aprendizado, com função passiva, limitada à recepção das informações transmitidas por um docente, responsável pela transmissão ativa de conhecimentos que o discente não possui. Nesse tipo de processo de aprendizagem, a preocupação fica centrada na mensagem, no conteúdo transmitido. Não se leva em conta a pessoa como interlocutor (Gracia, 1998).

Este é o caso dos modelos doutrinal e neutro do ensino da bioética. $O$ modelo da doutrina é clássico em todas as culturas; apresenta-se desde cedo na cultura ocidental. A função do processo de formação é unidireccional e tem como propósito adequar a conduta dos novatos às regras dadas.

Trata-se da transmissao de conhecimento de quem os possui aos que não os têm. A função de ensinar, neste caso, é fazer com que as novas gerações assumam como próprios os conheciemntos que lhes são transmitidos por gerações mais velhas. É um processo de transmissao ou de entrega e recepção de conhecimentos (Gracia, 1998).

As normas morais não são discutidas ou interpretadas. Este foi o modelo para ensino de moral nas tradições religiosas doutrinárias, nos grupos políticos e filosóficos e, mesmo, na formação profissional da saúde. O que se pretendia era criar credo de fiéis seguidores. Assim, a "instrução moral" assumia um caráter de movimento ideológico ou treinamento militar (Gracia, 1998).

Como fruto da tradição liberal surge o modelo neutral ou informativo do ensino de ética. $\mathrm{Na}$ disputa entre católicos e protestantes, os reformadores radicais foram os primeiros a defender a liberdade de consciência, advogando que cada um deveria viver livremente de acordo com suas crenças religiosas (Gracia, 1998).

O liberalismo não se restringiu à liberdade religiosa e foi gradualmente expandindo seu espaço, tornando-se o que conhecemos, hoje, com o nome de liberdade de pensamento e liberdade política. Assim, ninguém pode proibir-lhe de conduzir sua vida de acordo com suas crenças ou seus ideais políticos. Essa é a fonte dos regimes democráticos baseados nos princípios do 
pluralismo político. O pluralismo é a origem e também a consequência do princípio da liberdade de consciência, que reconhece a existência de diferentes crenças religiosas, políticas, culturais, estéticas e morais. A uniformidade nestas questões jamais será alcançada, pois não se trata de equações matemáticas, com exclusivo uso da razão e da demonstração. Como o compromisso político ou gosto artístico, as questões éticas também não são regidas pela mesma lógica que os tratados de álgebra ou trigonometria. Em questões práticas, tais como a ética e a política, a lógica demonstrativa não pode resolver os problemas, equacionando-se sempre de uma única forma. Numa mesma situação, pessoas diferentes podem resolver os problemas de forma distinta, porém com soluções igualmente razoáveis ou prudentes. Uma mesma pessoa também pode resolver situações semelhantes de forma diferente, a depender dos períodos de sua vida. (Gracia, 1998).

Este foi o grande descobrimento da mentalidade liberal e sua grande contribuição: todo ser humano tem direito a viver sua vida de acordo com seu sistema de valores e crenças. Observa-se nesta afirmação um reconhecimento moral de grande importância: como se passou a considerar todos os seres humanos como dignos de respeito e dotados de qualidade intrínseca moral, todos são sujeitos morais. Ou seja, os seres humanos, a partir do liberalismo, são tidos como livres, autônomos, iguais, até mesmo para as questões morais (Gracia, 1998).

Com isso, dá-se, também, a "privatização" de algumas áreas da vida humana, que são tidas como "protegidas pelo direito à liberdade de consciência". São assuntos privados, protegidos pelo direito à privacidade pessoal. Nada pode adentrar no santuário da intimidade sem a devida permissão da própria pessoa. A partir daí, lentamente, foi tornando-se consistente na mentalidade liberal moderna a neutralidade nos conflitos em questões de valores (Gracia, 1998).

Estes assuntos são considerados privados e íntimos; portanto, sobre eles não se discute, muito menos em público. Cada um sabe como deve manejar sua vida de acordo com suas crenças pessoais e valores. Este princípio de neutralidade sobre teorias de valores morais só aumentou, apresentando seu auge com a mentalidade positivista durante a segunda 
metade do século XIX. Assim, não há discussão possível sobre valores. As opções são mais emocionais do que racionais, cabe respeitar, porém não existe argumentação (Gracia, 1998).

Esta tese da neutralidade sobre as teorias de valores morais, deixou de ter vigência em filosofia nas primeiras décadas do século $X X$, embora ainda mantenha sua importância em outras áreas (Gracia, 1998).

Além dos modelos doutrinadores e neutros para o ensino da ética, temos o modelo coerentista ou clarificador, cujo objetivo não é transmitir um conjunto de valores, mas ajudar os alunos a tomar consciência das crenças e comportamentos considerados significativos e que deveriam ser tomados em conta nas suas ações. Opta-se, nesta corrente, por um processo de clarificação de valores que não tem a pretensão de diferenciar uns valores em detrimento de outros, mas apenas obter uma melhor integração das crenças, sentimentos e comportamentos. O que está em jogo não é a análise de valores ou crenças, mas imprimir maior coerência entre as crenças que o aluno tem e seus padrões de comportamento. Não se trata de discutir acerca do valores, mas que cada qual busque a coerência entre estes e sua vida prática.(Gracia 1998).

Aqueles que apoiam a clarificação de valores estabelecem duas propostas principais para o ensino de moral nas escolas. A primeira é ajudar os alunos a compreender e desenvolver seus próprios valores. A segunda é inculcar o respeito pelos valores dos outros. Os defensores da clarificação de valores acreditam que esta seja uma alternativa de ensino à doutrinação. Os valores são relativos e o único princípio que deve ser considerado é que todos devem aprender a respeitar, a tolerar os valores dos outros. Em questões de valor, portanto, deve ser "neutro". Esta neutralidade não deve ser considerada como ausência de tomada de posição em relação aos próprios valores, mas como uma abstenção de tomada de posição de em relação aos valores dos demais, ainda que sejam vistas como escolhas equivocadas (Gracia, 1998).

$\mathrm{Na}$ educação, isto pode ter consequências complicadas. Por exemplo, na educação infantil, tratar todas as opiniões morais como igualmente válidas pode incentivar nas crianças um falso subjetivismo, do tipo "eu tenho a minha própria opinião e você tem a sua". Sem quem possa dizer qual está correta, 
pois todas são válidas. A tolerância e o respeito mútuo que instruem a vertente educativa que aposta no simples esclarecimento de valores são demasiadamente indiferenciadas. Por exemplo, se as crianças vêm para a escola pensando que negros, judeus, católicos e/ou homossexuais são seres inferiores que não devem ter os mesmos direitos que os demais, isto não só exige a crítica, mas uma clarificação dos valores das crianças, o que implicará uma tomada de posição, ainda que implicitamente. Assim, na clarificação existe a transmissão de valores, pois, entre outras coisas, admite que não há nada isento de valores, ainda que cada qual tenha os seus próprios. A questão está em definir se tal neutralidade, ainda que elucidando críticas, seria a melhor forma para a educação em valores. Muitos programas de ética e bioética, especialmente nos países de tradição mais liberal, investem nesta vertente educativa. Os países latinos não se encaixam nisso. O objetivo desses programas é o de expor "prós e contras" das diferentes posturas, sem emitir juízos morais sobre elas e tampouco optar por uma ou outra. A única regra universalmente válida é a garantia da maior neutralidade possível (Gracia, 1998).

No processo de aprendizagem da ética deve-se levar em conta que o modo, o ritmo e a cronologia se dão de maneira diferenciada nos discentes. Não se aprende em ordem sequencial os conhecimentos, as habilidades e as atitudes. Parece ser justamente o contrário: primeiro aprendemos as atitudes, depois as habilidades e, os somente por fim, adquirimos o conhecimento (Gracia, 1998).

Assim, no ensino da ética requer-se aprofundamento nas questões relativas ao juízo moral e sua fundamentação com justificações e argumentações responsáveis, razoáveis e prudentes.

No caso da saúde, o ensino da ética tem como objetivo preparar os profissionais para o processo de tomada de decisões e melhorar a qualidade da assistência prestada, incorporando os valores na ponderação e deliberação dos conflitos morais nos cuidados prestados.

Aprender a emitir e justificar juízos leva-nos ao modelo socrático ou deliberativo de ensino da ética ou bioética. 
Sócrates não doutrinava, isto é, não ensinava uma doutrina. E tampouco defendia a neutralidade dos valores. Pelo contrário, se mostrava muito provocador em sua análise, nela investindo tempo e sua sagaz capacidade intelectual. Tal investimento conferia nitidez não tanto para dizer o que eram as virtudes, como a piedade, mas, sim, para entender o que não era. E fazia sua argumentação baseado na razão. Sócrates utilizava a razão para encontrar inconsistências nas proposições tomadas como corretas pelos respondentes de suas indagações provocativas. Não queria, com isso, que os valores fossem os mesmos para todos. Mas em todos os casos, os valores tinham de ser "razoáveis" (Gracia, 1998).

O método Socrático é uma metodologia em que predomina o diálogo ágil, o debate frutífero e a reflexão clareadora do que é razoável e prudente. Quando aplicado no ensino de bioética, facilita a interação grupal e a discussão deliberativa (Gottschalk, 2007).

A aprendizagem não ocorre pela passagem de conteúdos, mas realizase em um processo de identificação de problemas. O propósito é motivar o educando a encontrar, por intermédio de seu próprio esforço intelectual, respostas a um problema ético.

A maiêutica socrática é um procedimento sistemático com objetivo de "sacar à luz" o melhor de cada um. Não impõe nada à pessoa, porém a ajuda a encontrar em si mesma o que tem de melhor. A conversão se dá em seu interior, com o auxílio do mestre, que atua com uma "parteira”. (Gracia, 1998).

O método socrático pressupõe a existência de essências por trás das múltiplas manifestações de nossos conceitos, como os de virtude, justiça, temperança, coragem. Eram os significados precisos e exatos desses conceitos que Sócrates investigava por meio de conjecturas e refutações, sempre partindo das crenças iniciais de seus interlocutores.

O método de refutação tem muito mais um caráter "negativo"; sua finalidade é levar a razão a pensar sobre o que não é determinado conceito, mas não definir o que é. Razoável será o que passar no teste de refutação, mas isso não significa que ele é completamente racional, ou seja, que deve ser igual para todos. Por exemplo, as crenças, de qualquer natureza, políticas e 
religiosas, hão de ser razoáveis, mas não completamente racionais ou arbitrárias.

O procedimento intelectual para a tomada de decisões razoáveis é avaliado no presente estudo. Entretanto, a deliberação não se resume ao âmbito intelectual. Espraia-se para o atitudinal, pois para deliberar faz-se necessário ter certas virtudes: pensar que o outro pode ter razão, pelo menos tanto quanto eu tenho; que seu ponto de vista pode me enriquecer, pode me servir para eu ser mais prudente; ter capacidade de escuta e compreensão dos pontos de vista discrepantes; assumir o esforço de dar razão às opções de valor, apesar da dificuldade que representa; ter a capacidade de aceitar que não se é infalível, que necessitamos dos outros; que, no debate, os outros podem ter razão em seus argumentos, ainda que com juízos diferentes dos nossos; e que nossos próprios pontos de vista, opiniões e juízos não esgotam o caso. Enfim, para deliberar, se necessita uma certa dose de humildade intelectual (Gracia, 1998).

Para identificar, analisar e hierarquizar as dimensões valorativas presentes em situações moralmente dilemáticas ou problemáticas é preciso deliberar. No processo de deliberação ética, busca-se analisar os problemas éticos da maneira mais extensa possível, portanto, há que se ponderar valores, princípios, fatos, circunstâncias ou consequências previsíveis a fim de identificar um leque de cursos de ação possíveis (Gracia, 2001). A deliberação consiste na ponderação dos intervenientes em um fato concreto, a fim de se tornar uma decisão razoável e prudente.

Segundo La Taille (2006), os valores morais devem ser objeto de reflexão, uma vez que podem ser fruto do inconsciente, ou seja, movem as ações sem que tenhamos a consciência disto. O desejável é a tomada de consciência. No âmbito moral, esta tomada de consciência é necessária, pois somente temos liberdade se somos capazes de fazer escolhas conscientes, ou seja, autônomas. Tomar consciência de nossos valores, refletir sobre eles e, se necessário, modificá-los, eis o papel da razão como instância reguladora do juízo moral.

O juízo moral corresponde ao equacionamento moral, que consiste na identificação, análise e hierarquização de dimensões morais presentes em 
situações moralmente problemáticas. Nestas ocasiões, há de dispor em uma hierarquia qual é a melhor ação, porém, nem sempre as dimensões moralmente conflitivas apresentam-se de maneira clara, neste momento é que a deliberação torna-se ainda mais essencial (La Taille, 2006; Gracia, 2000).

Em geral, alcançamos uma vivência ética quando conseguimos estabelecer certa coerência entre os diversos elementos do universo moral: liberdade, consciência, lei, felicidade, obrigações, deveres, direitos, valores, justiça, verdade, felicidade. Ações educativas em ética e bioética têm de contribuir para ordenar estas questões nas argumentações para as experiências nos âmbitos práticos, por exemplo, a saúde, e nela, a atenção básica.

Assim, a questão central nas ações educativas em ética e bioética é: conseguir um arranjo metodológico capaz de propiciar a autoeducação autônoma, na qual o educando vá traçando o seu próprio caminho rumo a uma ordenação prudente dos elementos do universo moral, com vistas a alcançar a felicidade e contribuir para o bem comum. (La Taille, 2006; Gracia, 2000).

As ações educativas em ética e bioética, longe de serem transmissão de uma moral previamente estruturada, consistem na arte de elaborar a ética a partir do que se evidencia como desejável, e até indispensável, para que a comunidade humana em que se vive e as pessoas que a integram sejam mais humanas, mais alegres, mais justas, mais autênticas (Catão, 1997).

Assim, as ações educativas que partem do ser humano concreto, inserido na realidade têm mais chances de obter resultados eticamente válidos e profícuos (Catão, 1997).

A elaboração da ética é o progressivo desenvolvimento do sujeito ético e de seu senso moral, de forma que vá construindo sensibilidade espiritual para o bem e a maturidade para decisões autônomas (Catão, 1997).

As ações educativas em bioética têm de partir da realidade efetivamente dada dos educandos, não de um ideal humano de valores abstratos. Também não há de partir de lei, pois esta pertence a um universo distinto do moral, ainda que a este relacionado intimamente. A realidade sociocultural é algo que está posto e o papel das ações educativas em ética e bioética é contribuir para que o próprio educando administre esse dado de forma a não se comportar 
como determinado por ele, mas que se autodefina em relação a ele e decida autonomamente a ser e a agir como agente moral livre e autônomo, no qual tem de se constituir (Catão, 1997,).

Para a ativação de tal giro ético nos profissionais de saúde que atuam no SUS, são essenciais propostas educativas em bioética que levem à problematização da realidade vivida, à elucidação dos conceitos que possuem, à formação da capacidade de argumentação responsável e prudente. Com este propósito, o presente estudo utilizou o enfoque problematizador e tomou por fundamento a deliberação moral para a organização de uma iniciativa educativa para enfermeiros e médicos da ESF.

\subsection{O ENFOQUE PROBLEMATIZADOR NA FORMAÇÃO DE PROFISSIONAIS DE SAÚDE}

O enfoque problematizador considera que o saber em bioética compõese de um conjunto de conhecimentos que não é mera especulação sem relevância prática, mas a fundação sobre a qual será possível construir a aprendizagem das habilidades que permitam identificar os conflitos éticos que subjazem na vida diária do trabalho dos profissionais de saúde e analisá-los criticamente para tomar decisões que sejam eticamente consistentes e publicamente sustentáveis.

De fato, a modificação das atitudes é algo inerente ao próprio processo de aprendizagem de conhecimentos e habilidades e se dá também de forma progressiva. Espera-se que os profissionais transitem de uma primeira fase de receptividade, maior sensibilidade e atenção aos aspectos éticos da prática assistencial a uma segunda onde buscarão dar respostas aos que os identificarem na primeira; até chegar na terceira, de interiorização, que gerará atitudes duradouras que melhorarão a prática profissional cotidiana. Sem isso, o processo de formação em bioética carecerá de sentido.

Em consonância com algumas apostas para a formação dos profissionais de saúde para o SUS, há de se configurar, também nas iniciativas educativas em bioética, múltiplas formas de ação: produção de saberes e de 
práticas sociais que instituem agentes autônomos; aprendizados permanentes que não sejam práticas de modelagem sobre especialismos naturalizados; formação como processo questionador que escape da produção de profissionais como "mercadorias amorfas, despotencializadas, silenciosas, serializadas" (Mattos, 2006, p. 137).

Os objetivos mais fáceis de serem diretamente abordados são relativos aos conhecimentos e habilidades, entretanto, a finalidade do ensino da bioética tem de ser o aperfeiçoamento das atitudes e do caráter. Isto implica a necessidade de uma estratégia de ensino de caráter problematizado, mais propícia a provocar mudanças atitudinais, como é o enfoque maiêutico.

Parece que a opção pedagógica da "problematização" como guia na elaboração de sequências de atividades para aprendizagem em cursos de bioética pode facilitar a operacionalização, nos cursos, do enfoque socrático, potencializando sua capacidade de transformação individual e introduzindo a questão grupal e contextual que são importantes para atenção básica.

A "problematização" considera que, frente a um mundo de mudanças rápidas, o mais importante não são os conhecimentos, mas, sim, a capacidade para detectar problemas reais e buscar-lhes solução original e criativa. Assim, busca desenvolver a capacidade de "fazer perguntas relevantes" nas distintas situações vividas para que, compreendendo melhor a realidade, a pessoa possa resolver conflitos e gerar transformações de maneira mais autônoma e responsável. A "problematização" almeja desenvolver a capacidade de observação da realidade imediata, circundante, e também da global e estrutural, a fim de detectar recursos, identificar os problemas que obstaculizam um uso eficiente e equitativo desses recursos e encontrar formas de organização do trabalho e da ação coletiva para consegui-lo (Bordenave, 1982).

Por estas considerações, em princípio, parece que o enfoque socrático e a opção problematizadora se aproximam, enquanto estratégia de ensino. Ambas buscam despertar a capacidade de fazer perguntas relevantes, a partir da sensível e acurada observação e compreensão da realidade cotidiana e estrutural, para encontrar soluções criativas. Estas são habilidades e disposições essenciais para a deliberação moral em conflitos de valores, que 
consiste em problematizar eticamente estas situações vividas na clínica para encontrar cursos de ação alternativos, o que exige criatividade e inovação.

As dimensões problematizadoras assumem a construção do conhecimento como traço definidor da apropriação de informações e explicações da realidade, tomando-a como ponto de partida e chegada do processo de aprendizagem (Batista, 2005).

A problematização parte das formulações de Paulo Freire para encontrar um sentido de inserção crítica na realidade, de onde retira os elementos que conferirão significado e direção às aprendizagens. No movimento açãoreflexão-ação, os conhecimentos são elaborados, considerando a rede de determinantes contextuais, as implicações pessoais e as interações entre os diferentes sujeitos que aprendem e ensinam.

Segundo Batista (2005), Bordenave e Pereira, construindo um modelo de problematização, consolidaram, com a proposição de Charles Maguerez, o Método de Arco. Este consiste no itinerário contínuo, como sugere a denominação de arco: observação da realidade (construção do problema); identificação dos pontos-chaves; teorização a hipóteses de solução, aplicação à realidade.

O diagrama, a seguir, que nos ajudará a representar esta pedagogia problematizadora, pode ser bastante simples. Chavez Maguerez, seu autor, o chamou de "método de arco".

Figura 1 Método de arco

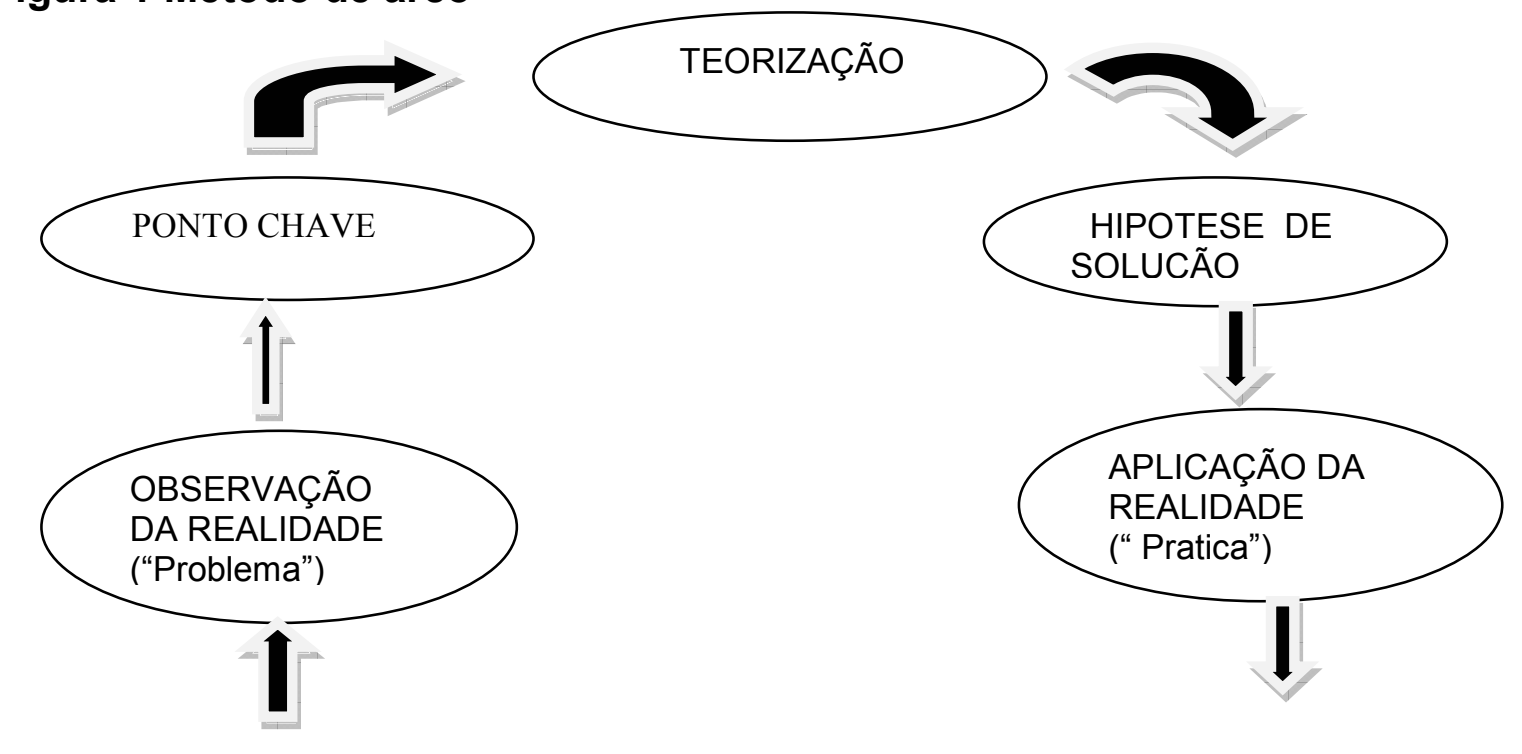


O diagrama, esquematicamente, representa o processo "ensinoaprendizagem", que parte da seleção de um determinado aspecto na Realidade, devendo começar a levar os alunos a observar a realidade em si, com seus próprios olhos. Ao observar a realidade, os alunos expressam suas percepções pessoais, efetuando assim uma primeira "leitura sincrética" ou ingênua da realidade. Quando não é possível a observação direta da realidade, os meios audiovisuais, os modelos, a experiência recontada, dentre outros, permitem trazer a realidade até os alunos. Claro que isto se fará com perdas de detalhes e de informação inerentes às representações do real, mas, muitas vezes, como no ensino da bioética, é o possível, pois se trabalha, usualmente, a partir de situações vividas, geradoras de conflitos, de problemas éticos para os que nela estavam envolvidos.

Em um segundo momento ou fase do itinerário, os alunos separam, no que foi observado, o que é verdadeiramente importante do que é puramente superficial ou contingente. Melhor dizendo, identifica os pontos-chaves do problema ou assunto em questão e as variáveis mais determinantes da situação. Esta etapa da problematização constitui uma das razões mais importantes da superioridade desta pedagogia sobre as de transmissão e condicionamento.

No terceiro momento, os alunos passam à teorização do problema ao se perguntar o "porquê" das coisas observadas. Ainda que o papel do professor seja sempre importante como estímulo para que os alunos participem ativamente, nesta fase de teorização sua contribuição é fundamental, pois a tarefa de teorizar é sempre difícil e ainda mais quando não se possui o hábito de fazê-lo, como é, em geral, o caso de adultos em treinamento, situação para o qual foi proposto o Método do Arco. Mas podemos dizer que o hábito de teorizar problemas éticos vividos com as teorias da ética, sejam de cunho filosófico, psicológico, social ou antropológico, não é hábito dos profissionais de saúde, em geral. Trata-se então do caso de apelar para conhecimentos no diaa-dia e outros de maneira simplificada, de fácil de comprovação, para paulatinamente ir apresentando outras elaborações mais refinadas.

A teorização bem sucedida proporciona que o aluno "entenda" o problema em suas manifestações empíricas ou situacionais e nos princípios 
teóricos que os explicam. Essa etapa de teorização, que compreende operações analíticas da inteligência, é altamente enriquecedora e permite 0 crescimento mental dos alunos. Eles passam, pelo próprio esforço, do domínio das "operações concretas" para as "operações abstratas" e isto lhes confere um poder de generalização e extrapolação considerável. Eis, então, outra razão da superioridade da pedagogia da problematização sobre as de transmissão e condicionamento.

No caso da bioética, ele passa da leitura da situação problemática eticamente como simples discordância, "briga", para compreender suas implicações como conflitos de valores.

Confrontada a realidade com sua teorização, o aluno se vê naturalmente movido a uma quarta fase do itinerário: a formulação de hipóteses de solução para o problema em estudo. É aqui onde deve ser cultivada a originalidade e a criatividade inventiva para que os alunos deixem sua imaginação livre e se acostumem a pensar de maneira inovadora. Como a teoria em geral é muito fértil e não tem amarras situacionais, algumas das hipóteses apresentadas podem ser válidas a princípio, porem não na prática. De modo que esta etapa deve conduzir o aprendiz a levar a termo provas de viabilidade e factibilidade, confrontando suas hipóteses de solução com os condicionamentos e limitações da própria realidade. A situação de grupo ajuda a esta confrontação "idealreal". Aqui, vemos outra vantagem desta pedagogia: o aluno usa a realidade para aprender com ela, ao mesmo tempo em que se prepara para transformála.

Na última fase, o aluno pratica e fixa as soluções que o grupo encontrou como sendo mais viáveis e aplicáveis. Aprende a generalizar o aprendido para utilização em situações diferentes e a discriminar em que circunstâncias não é possível ou conveniente a aplicação; sabendo qual escolher.

Através do exercício aperfeiçoa sua destreza e adquire domínio e competência no manejo das técnicas associadas à solução do problema.

Experiências de ensino-aprendizagem baseadas no enfoque problematizador mostram que este mobiliza, de forma significativa, os educandos em seus processos de aprendizagem, estabelecendo-se 
movimentos de interesse, motivação, desenvolvimento de lideranças e do trabalho em grupo (Batista, 1982).

Segundo Batista, (1982), o enfoque problematizador envolve:

$>$ reconhecimento da atividade e interatividade da pessoa em seus processos de conhecer, explicar e intervir no mundo;

$>$ construção de propostas de formação e atuação que tomem a prática como objeto de reflexão e de produção de conhecimento;

> apropriação de referenciais teórico-metodológicos em uma dimensão reflexiva que toma o questionamento e a busca sistemática de respostas como pilares fundamentais.

$>$ reconhecimento da perspectiva interdisciplinar como um pressuposto nuclear do processo, o que demanda atitudes de abertura para novas parcerias e de questionamento para intervenção e transformação da realidade.

No enfoque problematizador, a transmissão fiel de conceitos, fórmulas, receitas, procedimentos, aquisição de hábitos fixos e rotinas de trabalho não são o mais importante. O central é desenvolver a capacidade de observar tanto a realidade imediata ou circundante, como a global e estrutural; detectar todos os recursos a que se pudesse lançar mão; identificar os problemas que obstaculizam um uso eficiente e eqüitativo dos ditos recursos; localizar as tecnologias disponíveis para usar melhor os recursos ou até inventar novas tecnologias apropriadas; encontrar formas de organização do trabalho e da ação coletiva para conseguir tudo anteriormente citado.

Nesse enfoque, não separa a transformação individual da transformação social, por isso o ensino-aprendizagem desenvolve-se em situação grupal.

Podem-se esperar da pedagogia da problematização consequências nos planos pessoal e social. No plano pessoal, espera-se:

- educando constantemente ativo, observando, formulando perguntas, expressando percepções e opiniões;

- educando motivado pela percepção de problemas reais cuja solução se converte em "reforço";

- aprendizagem ligada a aspectos significativos da realidade; 
-desenvolvimento das habilidades intelectuais de observação, análise, avaliação, compreensão, extrapolação;

- superação de conflitos como integrante próprio da aprendizagem grupal;

- igualdade de estatus entre educador e educando.

No plano social, espera-se:

-população conhecedora de sua própria realidade e reação à valorização excessiva do externo ou sua imitação;

- métodos e instituições originais, adequadas à própria realidade;

- cooperação na busca de soluções a problemas comuns;

- redução da necessidade de um líder, pois os líderes são emergenciais;

- elevação do nível médio de desenvolvimento intelectual da população, graças

à maior estimulação e desafio;

-Resistência às relações de dominação, com vistas á emancipação;

O objetivo fundamental da ação educativa é desenvolver a personalidade integral do educando, sua capacidade de pensar e raciocinar, seus e hábitos de responsabilidade e cooperação.

No ensino da bioética, espera-se que o profissional - educando participe ativamente e seja agente de sua própria transformação e das modificações na prática assistencial, capacitando-se para detectar os problemas éticos que emergem da realidade cotidiana, buscando soluções originais, criativas e prudentes. O modelo de deliberação proposto pelo professor Diego Gracia,(1998), tem como peculiaridade permitir que a partir da situação clínica se inclua o que concorre para a situação vivida.

Assim, reforça-se o entendimento do diálogo possível com o ensino problematizador, já que a deliberação moral requer a capacidade de fazer perguntas relevantes nas situações clínicas para compreender melhor seus fatos e os valores em conflitos e, a partir daí, traçar soluções possíveis e encontrar o curso ótimo de ação. 


\section{DELIBERAÇÃO MORAL}

Para identificar, analisar e hierarquizar as dimensões morais presentes em situações moralmente dilemáticas ou problemáticas é preciso deliberar.

No processo de deliberação ética, busca-se analisar os problemas éticos em toda a sua extensão. Portanto, há que se ponderar tanto valores e princípios implicados, quanto as circunstâncias e consequências do caso. Isso permite a identificação de todos ou da maioria dos cursos de ação possíveis (Gracia, 2001).

Gracia (2001), compreende por problema ético tudo aquilo que o sujeito assim o considera. Dessa forma, se uma única pessoa considerar determinada situação como geradora de um problema ético, já é suficiente para a mesma ser considerada como tal, pois ao menos para ela já o é.

A deliberação consiste na ponderação dos intervenientes em um fato concreto, a fim de se tomar uma decisão razoável e prudente. Não se trata de tomar decisões certas, mas prudentes, por mais que sejam apenas prováveis. Uma decisão é prudente quando, apesar de não gozar de certeza, resulta ótima para o momento concreto. Isto significa que uma decisão prudente é passível de realização, tomando em conta as circunstâncias existentes e as consequências previsíveis (Gracia, 2001)

Deliberar não é explicar. Deliberar é uma arte, baseada no respeito mútuo, em certo grau de humildade ou modéstia intelectual, e o desejo de enriquecer a própria compreensão dos fatos por meio da escuta e intercâmbio de opiniões e argumentos com os implicados no processo deliberativo, numa atitude imaginativa e empático-crítica. Requer habilidades e traços de caráter, que são fomentados no transcurso da deliberação. A experiência mostra que o próprio processo deliberativo atua como oportunidade educativa, melhorando a capacidade das pessoas implicadas. Deliberar é um processo de autoeducação, quase autoanálise. Ao se deliberar, tem que se admitir que existem mais soluções dos que as vislumbradas à primeira vista. Tem que se estar abertos a novos descobrimentos, disposto a ser por eles surpreendidos. 
É esta abertura que interessa. Quando a equipe de saúde e os usuários dos serviços põem-se em diálogo para alcançar uma decisão, têm que admitir que podem mudar de opinião, ou ver as coisas de forma diferente. São traços fundamentais da deliberação a pluralidade, a intersubjetividade, a capacidade de compreender a situação humana, a responsabilidade e determinação dos fins (Dordoni, 2007).

Aplicar o método de deliberação é executar um procedimento mais difícil do que se pode supor à primeira vista, pois implica aceitar alguns pontos que, mais do que procedimentais, são atitudinais. Temos de reconhecer que não somos onipotentes, que não temos respostas a priori para todas as questões, que podemos nos equivocar que nosso ponto de vista é sempre parcial e que, para aumentar nossa prudência, é importante ampliar as perspectivas, o que requer não apenas tempo, mas a participação de outras pessoas. Assim, a deliberação não é apenas individual, mas coletiva. E neste processo coletivo temos de ser capazes de escutar os outros, de pensar que podem contribuir para nosso conhecimento, especialmente quanto mais distintos dos nossos forem seus pontos de vista. É claro que isto exige, dos profissionais de saúde, humildade intelectual, maturidade psicológica e humana, pois deliberar é uma atividade que exige não só conhecimentos, mas habilidades e certas atitudes fundamentais. Por isso que aprender a deliberar leva a um conhecimento de si próprio e a um respeito mais profundo pelos outros. A deliberação, assim entendida, é uma escola de vida. Uma das falhas da educação na atualidade, desde os primeiros anos escolares, é não se ensina a deliberar, mas a impor o próprio ponto de vista, a dogmatizar as próprias afirmações, a optar pelos cursos extremos (Gracia, 2004a).

A ação educativa avaliada no estudo ancora-se na bioética deliberativa, ou seja, na bioética que se calca na deliberação, na hermenêutica, na responsabilidade, na prudência e na utilização da a linguagem ética dos fatos, valores e deveres, segundo a proposição de Diego Gracia (Gracia, 2001; Gracia, 2007; Gracia, 2009; Zoboli, 2010).

A experiência é sempre um dado último e irredutível, qual não se mostra, não se demonstra. Ela é inexplicável. Em outras palavras, a explicação da experiência já não é mais experiência, ao contrário, é um ponto de partida da 
explicação e constitui um fato nos termos fenomenológicos. Assim, a experiência se tem ou não se tem e, uma vez que se tenha, cabem a ela todos os tipos de explicações. Mas, sem a experiência qualquer explicação fica incabível. A experiência moral não escapa a estas generalidades das experiências (Pose, Gracia, 2006).

A experiência moral é a experiência da obrigação e essa configura um fato, um fato moral de onde partem as explicações (as teorias éticas). A experiência moral se expressa no fato de que todo ser humano faz juízos morais, sente que há coisas que deve fazer e outras que não deve fazer e pede contas a si próprio e aos demais do que vai fazer e do que fez. Como experiência, a experiência moral é irredutível, isto é, não se reduz a nenhum outro tipo de experiência humana, por exemplo, a religiosa. Destas constatações, decorrem as três características da experiência moral: é universal, imperativa e justificatória. É universal porque não há ser humano que escape da experiência moral, ainda que não o faça conscientemente ou que não se debruce sobre ela para refletir. Por mandar, dar ordens do que fazer com a própria vida e com a dos demais, a experiência moral é imperativa. E é justificatória, pois tanto do ponto de vista que fazemos como do que deixamos de fazer, nos vemos obrigados a pedir e dar contas, a justificar. É sujeito moral quem experimenta estas três notas em si mesmo (Pose, Gracia, 2006).

Essa é a estrutura formal da obrigação moral; os conteúdos, temos que defini-los. Esse é o espaço da deliberação moral. Com qualquer conteúdo, e este pode variar muito, o moral mantém seu caráter imperativo. Os conteúdos são algo que importam ao espaço deliberativo porque não estão dados a priori tampouco de uma vez por todas, mas é algo que vai sendo definido, individual, social e historicamente, num processo de descobrimento, invenção, valoração e escolha. A obrigação configura a experiência moral originária universal e irredutível, enquanto que as opções concretas são sempre algo ulterior a cada pessoa. Mas sem a experiência prévia da obrigação moral, a eleição não teria sentido.

Temos que dar por suposta a experiência da obrigação como fundamento último das nossas ações, para que se tornem possíveis as opções 
posteriores que as definem e também as opções posteriores que deem fim à nossa vida moral. (Pose, Gracia, 2006).

$\mathrm{Na}$ fundamentação moral temos, como qualquer fundamentação, que responder a um por quê. O "por" nos está dado formalmente como obrigação, é o que nos lança à justificação ou fundamentação. O "que" refere-se ao conteúdo da obrigação. Todo juízo moral tem uma obrigação, sobre a qual inserimos um conteúdo concreto. Responder ao por quê corresponde a fundamentar o juízo de dever, num passo a mais. Para estas explicações justificativas apelamos, mais comumente, a valores, que são a estimação de algo anteriormente percebido e que torna possível a manifestação dos valores. Esse algo anterior são os fatos. Os valores estão sempre suportados por fatos observáveis por qualquer um e por isso são indicadores muitos fiáveis sobre os quais cabe fundamentar um juízo moral (Pose, Gracia, 2006).

Por exemplo, quando nos empenhamos para responder um porque para o juízo de dever "deves pagar os impostos", podemos justificar esta obrigação explicando que ao pagar os impostos podemos usufruir certos serviços que seriam impossibilitados se não os pagássemos, como viajar de carro pelas estradas. Assim, de um fato (os serviços) brotam valores, por exemplo, a comodidade de viajar de automóvel e, também, deveres, o dever de pagar impostos pertinentes para que conduzir um carro pela estrada seja possível (Pose, Gracia, 2006).

$O$ encadeamento de fatos, valores e deveres são fundamentais na construção dos raciocínios éticos. Na deliberação, segundo a proposta de, Diego Gracia, (1998), estes três âmbitos da experiência moral constituirão os três momentos de um procedimento para tomada de decisão, o deliberativo. Daí a bioética deliberativa.

A fundamentação chega ao nível dos fatos, mas a argumentação é feita no âmbito dos valores. São os valores que nos obrigam moralmente e não os fatos, embora estes sejam suportes dos primeiros. A ética não vem dada, há que ser construída em três momentos: o cognitivo (dos fatos e que se orienta pela lógica cognitiva); o da valorização, estimação ou preferências (dos valores); e o da realização, que é o mais propriamente moral, é o memento do dever, do ato voluntário (Zoboli 2010). 
O agir moral envolve três faculdades da inteligência humana: cognitiva (fatos); emocional (valores); volitiva (deveres). Ou seja, o momento valorativo requer o complemento do volitivo, da disposição para realizar os valores em um projeto prático.

Fato é todo dado de percepção, portanto, algo objetivo, contundente e impositivo. De maneira geral, são dados da realidade observáveis por qualquer um. A percepção ou observação de um fato pode ser direta ou indireta. É direta quando essas sensações são obtidas através de uma representação ou qualquer outro meio complementar. Por exemplo, posso perceber o osso do corpo diretamente por meio de uma dissecação ou indiretamente por uma radiografia (Pose, Gracia, 2006).

Não podemos confundir fatos com valores. Os fatos se percebem e os valores se estimam. E estimar não é perceber, ainda que admitamos que sem a percepção não seria possível a estimação (Pose, Gracia, 2006).

Parar nos fatos, sem considerar valores, levou à moral positiva, que identifica o bom como útil nos âmbitos pessoal, familiar e social. O crédito objetivo era fazer triunfar "instintos de simpatia e solidariedade" sobre os apuramentos egoístas, a fim de instaurar um "amor universal" (Gracia, 2004).

Na bioética deliberativa, segundo a proposta de Gracia, (2004), os fatos são importantes, pois fazer juízos morais com dados ruins é perigoso. Os fatos permitem um melhor conhecimento da realidade, porém conformam apenas um dos âmbitos da deliberação. Há de se evitar dois equívocos comuns à bioética, ignorar os fatos ou tê-los mal esclarecidos para as decisões necessárias; reduzir a ética aos fatos em uma falácia naturalista. Deliberamos sobre fatos, valores e deveres.

Os fatos sem os valores são cegos, mas os valores sem fatos são vazios. Fatos e valores são âmbitos distintos, mas relacionados, da experiência moral. Todos valoramos, estimamos. Valorar é uma ação necessária dos seres humanos, não há quem não valore. A valoração não equivale à percepção, embora desta necessite. A estimação está mais influenciada pelos sentimentos do que a percepção. A tudo que percebemos, necessariamente, atribuímos um valor. A intuição dos valores, como explica Gracia, (2004), ocorre por meio dos sentimentos, como a percepção das cores se dá pelos sentidos. Os valores 
não se veem não se tocam, não são dados concretos da sensação ou percepção. Ancoram-se nos fatos, sem com estes se identificarem. Ao ancorarem-se nos fatos é claro que não são exclusivamente sentido ou sentimento e tampouco se resumem à intuição, mas incluem construção individual, sócio-histórica e cultural. Assim, os valores têm algo de intuído e construído, ao mesmo tempo. Sobre a intuição, ou seja, do que tomo conhecimento sem qualquer mediação, posso fazer elaborar meus raciocínios. Disso também decorre que não há fatos puros, os fatos vêm com os valores, como seus depositários que são como diz Scheler, (2001).

Do ponto psicológico, o valor corresponde a um "investimento afetivo" (La Taille, 2006 p.55). Nossa relação com os objetivos é mediada por estruturas de assimilação, que Ihes conferem sentido, e também por afetos, que Ihes conferem valor positivo ou negativo, estimam-nos positiva ou negativamente (La Taille 2006)

A teoria acerca dos valores não começa antes do século XVIII. As primeiras são escocesas, e para economia. Em filosofia, é difícil encontrar uma concepção de valor, uma teoria por assim dizer; todos falam de valor, mas não o definem. Destaca-se Max Scheler, que desenvolveu a Ética Material dos Valores, a partir do que aprendeu como discípulo de Hurssel.

O mundo dos valores é escorregadio e complexo, crendo, alguns, que nele pode imperar o subjetivismo do tipo "eu gosto", "me agrada", "eu não gosto", "eu o valorizo positiva ou negativamente" (Cortina, 2007, p.24). Mas as coisas não são assim, não dependem simplesmente do gosto de cada um, "porque hay gustos que merecen palos" (Cortina, 2007, p. 25). A questão dos valores ultrapassa a esfera da instituição pessoal, da captação pessoal do valor e abarca o cultivo das predisposições necessárias para apreciá-los, para degustá-los. A educação em valores corresponde ao cultivo das condições que nos preparam para degustar certos valores. (Cortina 2007)

Os valores são qualidades reais das pessoas, das coisas, das ações; valem realmente e põem o mundo em condições para que os seres humanos possam habitá-lo. Um mundo injusto, insolidário, sem liberdades, sem beleza não reúne as mínimas condições de habitabilidade. E isso nos motiva, impele- 
nos a, criativamente, dar corpo aos valores de justiça, liberdade, solidariedade e beleza, por exemplo (Cortina 2007).

Assim como há fatos por toda parte, também há valores, já que os primeiros carregam sempre valores. Onde há um fato, há ao menos um valor. $\mathrm{E}$ como a todo valor corresponde um contravalor, ou desvalor, já somam dois valores a cada fato, mas pode haver muitos mais. Os fatos são únicos, ou chove ou não chove, mas os valores são diversos, isto é, plurais e polares, caro e barato, agradável e desagradável; justo e injusto; belo e feio (Pose, Gracia, 2006).

Como qualidades reais, ainda que não tenham a mesma objetividade dos fatos, os valores são, em grande medida, objetivos. Os dados de percepção são quase inapeláveis. Assim, os fatos, ao serem passíveis de observação, são muito objetivos, ainda que caibam discussões sobre eles. Os valores também se discutem, o que indica que tem algo de objetivo ou não faria sentido a discussão sobre eles. Por exemplo, quando alguém afirma que o quadro "Las Meninas", de Velásquez, é um belo quadro, não está dizendo unicamente que essa tela é bela para si, e sim que a qualidade "beleza" pertence ao quadro como seu atributo e que por isso o considera belo. Os valores costumam ser um descobrimento compartido por várias pessoas e avalizado pela opinião de expertos (Pose, Gracia, 2006).

Um valor não é um objeto, não é uma coisa, não é uma pessoa, mas está na coisa (uma bonita paisagem), na pessoa (uma pessoa solidária), em uma sociedade (uma sociedade respeitosa), em um sistema (um sistema econômico justo), nas ações (uma boa ação) (Cortina, 2007).

Os valores sustentam-se nos fatos e são de alguma forma ideias, porque não estão totalmente realizados. Constituem-se imagens-objetivo da prática profissional, por exemplo.

Para compreensão construtivista, tanto os valores como a idealização dos valores são construções humanas, Todos geramos esta construção ideal dos valores para podermos viver, dando sentido às nossas vidas. As idealizações dos valores funcionam como móbiles de nossas ações, da nossa vida prática. A filosofia também constrói mundos ideais, idealizações de valores: total felicidade; total justiça. Os valores perfeitos, em sua plenitude não 
estão realizados, ou seja, os valores não se encontram, e não se encontrarão, perfeitamente concretizados no mundo real, e é justamente a busca de sua realização, a disposição para lhes dar corpo, que nos move na prática, na vida moral.

Dos valores surgem os juízos valorativos, que se apoiam nos juízos de fato, ou de percepção. Quando dizemos que "a verdura está cara" ou que "a temperatura pela manhã está agradável" estamos fazendo e expressando juízos de valor. Esses, embora sutis, são os mais importantes, pois são os que dão sentido e motivam nossas vidas (Pose, Gracia, 2006).

Nas situações eticamente problemáticas da clínica, é nos juízos de valor que estão as discordâncias e é onde têm de se concentrar o maior exercício de diálogo. Por isso, nesta pesquisa, buscaremos diretrizes metodológicas na síntese realista.

Os valores conformam o planeta, onde nos movemos com a bússola e o mapa moral. Resultam de investimento afetivo, a estimação, e correspondem à energética da vida em geral e, em particular, da vida moral. Os valores podem ser assimilados intelectualmente, podem ser pensados, ou seja, podem ser objetos do conhecimento. Da mesma maneira, podem ser experimentados como investimentos afetivos que são. Cada um de nós tem que ter consciência de seus próprios valores, de seu próprio projeto de vida, do projeto de felicidade que move suas ações, pois nossa moral depende desse conhecimento. Esse conhecimento tem de ser tanto próprio, como temos que dar a conhecer aos outros quais são nossos valores. É um equivoco pensar que os valores que movem nossas ações estão ou são evidentes (La Taille, 2006).

Isto é essencial para uma bioética deliberativa, que compreende que os fatos carregam os valores e estes sustentam os deveres.

No âmbito dos deveres, encontra-se o que é mais próprio da ética e da bioética, pois a experiência moral é a experiência do dever.

A esfera do dever tem dois níveis: o "dever ideal" ou "deveria", o "dever realizável" ou "deve", isto é, o que "devo" fazer aqui e agora. O raciocínio moral se dá em ambos os níveis, ou seja, abarca o impossível necessário e categórico das proposições do tipo "deveria" e o possível de ser realizado e 
hipotético das proposições do tipo "deve". O dever moral é levar "o que há" ao "deveria" e no menor tempo possível; por isso, antes de chegar ao "deve" temos de passar pelo "deveria”, que é momento de idealidade (Zoboli, 2010).

Os valores têm como característica essencial a demandam de sua realização; requerem se tornar realidade; ganhar corpo. E isto é o próprio da ética: realizar valores. A ética não trata diretamente dos fatos, embora deles parta a deliberação. A ética também não trata dos valores como a axiologia. A ética trata dos deveres. E o dever define-se precisamente como o que toda pessoa tem que realizar, como se cuidasse de um tesouro: os valores (Pose, Gracia, 2006).

Em outras palavras, nosso único dever é realizar valores, isto é, tornálos realidade na vida cotidiana; concretizá-los.

Os deveres assentam-se em valores que nos clamam sua realização, concretização. A justiça nos pede que sejamos justos; a verdade, que sejamos verazes; o sagrado, que sejamos religiosos; se prometemos algo a alguém, cumprir a promessa; se contraímos uma dívida, pagá-la, e assim por diante. Com efeito, não há valor que deixe de reclamar-nos sua realização (Pose, Gracia, 2006). Esta é a experiência moral, o dever que sentimos, como nosso, de realizar valores. A experiência moral é ato introspectivo que se converte em fatos objetivos por meio da práxis, da operacionalização dos valores, quando estes ganham corpo, ou se encarnam, por exemplo, na prática, profissional de cada um de nós.

A esfera do "deveria" está fundada nos valores, pois somente os valores é que é devem ser (valores positivos) ou devem não ser (valores negativos ou desvalores) (Volkmer, 2006).

O mundo ideal, o mundo do "deveria", não resolve os problemas do cotidiano, pois esses se instalam no que chamamos de conflito de valores, onde todos os valores pedem, igualmente, por realização. Então, necessitamos de um outro tipo de projeção, mais cravada nos fatos, que nos aclare o que temos que fazer em cada caso concreto. Surge o nível do "deve".

O âmbito do "deveria" somado ao real indica o que devo fazer aqui e agora. Em outras palavras, "eu creio que deveria fazer $X$, mas nesta situação devo fazer Y". A opção entre os mundos, ou âmbitos da vida humana, do 
"deve" e do "deveria" sempre levou a posturas morais extremadas. É mister manter ambos articulados por meio da "responsabilidade moral", de decisões prudentes, responsáveis. A concretização dos valores se expressa nos juízos prescritivos ou normativos, ou seja, nos juízos de dever ou juízos morais. Esses são os que nos ordenam a realizar valores positivos e evitar sua negativa: "'deves cumprir tuas promessas"; "não deves mentir"; onde "cumprir as promessas" e "dizer a verdade" equivalem ao positivo (Pose, Gracia, 2006).

Os juízos de dever têm uma linguagem bastante peculiar. Expressam-se em termos do "deve" e "não deve". Usam linguagem imperativa, categórica, pois os juízos morais mandam e ordenam que façamos algumas coisas e evitemos outras tantas. A finalidade da linguagem dos deveres é ordenar a realidade (Pose, Gracia, 2006). Daí ser horizonte normativo, horizonte de vida boa.

Reconhecer os valores neste estudo de metassíntese tem por finalidade traçar o sentido no qual o enfermeiro ordena sua prática na atenção primária, no Brasil e em Portugal.

Fundamentar os juízos morais constitui uma tarefa difícil, custosa, que requer: análise dos fatos, valores e deveres; síntese responsável dos três âmbitos na ação, na prática. Quem analisa minuciosamente os fatos e despreza os valores, não age responsavelmente. Quem estima sobremaneira os valores e deprecia os fatos, não mostra responsabilidade (Pose, Gracia, 2006).

O raciocínio ético parte sempre de um sistema de referência prévio: o mundo ideal do "deveria". A partir deste elabora esboços, ou seja, propostas provisórias que contém suposições dos deveres a cumprir. Esses esboços morais têm de ser contratados com a referência prévia, a realidade e as consequências. É o componente "racional" da experiência moral (Gracia, 2008). Se distinguirmos a ética como o momento de deliberação racional sobre o conteúdo da moral, este seria o momento propriamente ético. Para além destas distinções, o que importa é reconhecer que, na experiência moral, uma vez elaborado o esboço, que está na idealidade do "deveria", temos que contrastá-lo com a realidade, para construir o âmbito do "deve". 
Assim, a experiência moral é sempre casuística, porque o contraste do esboço se dá em cada situação concreta. O esboço é genérico e abstrato; a experiência é concreta e específica. Sem o momento de concretude, da realidade, a vida moral, como qualquer outra atividade da razão humana, fica impossibilitada. A razão é geral e o processo de contraste é particular, e ambos ocorrem nos planos individual, social e histórico, Consequentemente, a racionalidade moral pode modificar-se; transformar-se lógica e historicamente; interferir para mudar a própria história. É inútil pensar que seja possível estabelecer uma racionalidade moral alheia ao contexto social e ao momento histórico. Mas, por outro lado, é ingênuo crer que ela se resume a uma convenção sócio-histórica. A razão moral é histórica, mas também instrumento de transformação da história, a partir da realização de seus móbiles morais, os valores (Garcia, 2008).

Como é logicamente impossível esgotar toda a realidade, abarcá-la por completo, os juízos de dever são sempre prováveis, ou seja, são juízos dialéticos e não apodíticos, ainda que expressos em linguagem imperativa e categórica.

Deliberar sobre deveres é dotar de conteúdo a experiência moral. Os conteúdos da ética são construídos intersubjetivamente. E, num sentido aristotélico, podemos dizer que visam unir "viver bem" com "agir bem", resultando em "ser feliz", ou seja, na felicidade ou no supremo bem. Esse não se equipara ao prazer ou às honras, a felicidade equivale ao bem que é bom e desejado por si mesmo e não em função de outros; ao bem que é causa para que todos os outros sejam bens (Gracia, 2008).

Os valores morais são os que, atualmente, cobram mais veemente sua realização na sociedade. Não que não sejam importantes os valores estéticos (beleza, elegância); os religiosos (o sagrado, o transcendente); os da saúde (a saúde, a agilidade); os intelectuais (o conhecimento, a evidência); os de utilidade (o útil, o eficaz), mas são os valores morais que estão mais em voga. Provavelmente, porque, com razão, percebamos que eles permitirão ordenar os demais de forma ajustada a nossa condição de pessoas. Os valores morais atuam como integradores dos demais, não como seus substitutos (Cortina, 2007). 
Como valores especificamente morais; temos a liberdade, a justiça, a solidariedade, a honestidade, a tolerância ativa, a disponibilidade ao diálogo, o respeito à humanidade nas demais pessoas e em si próprio (Cortina, 2007).

\subsection{O PROBLEMATISMO MORAL NA PRÁTICA CLÍNICA}

Em geral, o problema é um fato real, descoberto pelo ser humano e considerado por ele como algo contraditório (Pose, 2009).

Dessa forma, uma situação problemática será um problema moral quando o contraditório estiver na esfera dos valores, ou seja, um problema moral implica um conflito de valores.

Assim, com Pose, (2009), vimos que, na bioética clínica, chamamos de "problema moral" um caso clínico ou biomédico em que se descobre ter várias saídas possíveis.

O problematismo clínico-moral, segundo o mesmo autor, tem três momentos que o compõem:

a) O Caso Clínico: na medicina, tradicionalmente, o caso clínico equivale a qualquer processo mórbido individual, cuja descrição se recolhe na chamada história clínica.

$\mathrm{Na}$ bioética clínica, esse entendimento tradicional estende-se para qualquer processo individual ou coletivo que tem a ver com a prática diária dos profissionais de uma instituição de saúde. O caso clínico toma, então, um sentido amplo de qualquer situação na qual interagem os profissionais de Saúde, os usuários dos serviços e os gestores da instituição ou sistema de saúde. Haverá casos clínicos simples e complexos. Os últimos são os que comprometem mais partes e, por isso mesmo, costumam gerar mais problemas morais para quem é responsável pela decisão (Pose, 2009). Os mais simples são as situações mais sutis, as mais difíceis de serem descobertas como problemas éticos. E essas são as próprias da clínica na atenção básica situações do cotidiano que os profissionais de saúde vivem no seu trabalho e que, muitas vezes, passam despercebidas como problemas éticos, embora 
contenham conflito de valores. Ou, ainda, situações que, embora percebidas como "problema éticos" pelos profissionais, esses não conseguem expressar ou precisar os valores que estão em conflito. Poderíamos dizer que, então, não seria problema moral na clínica, pois a segunda condição, o ser descoberto como problema, não ocorre. Mas veja, é ser descoberto e não ser inventado, então, creio que aí está a função do 'experto' em bioética e um propósito da educação continuada dos profissionais de saúde para a deliberação moral: levá-los à problematização da realidade, da clínica, ou seja, levá-los a incluir os valores na clínica. $O$ fato de não serem descobertos não significa que os conflitos não estejam dados na realidade; estão e precisam ser descobertos para serem bem manejados e melhorarem a qualidade da atenção. Os problemas complexos são mais fáceis de descobrir, porque a tragicidade os marca; são as questões néon, bastante exploradas na literatura de Bioética e na formação profissional em ética, que é feita com a discussão dos casos paradigmáticos, extremos e complexos (Zoboli, 2003). Já as questões do cotidiano não são problematizadas, ou melhor, os valores que permeiam nossas situações cotidianas da saúde não são explorados, dialogados e, portanto, os conflitos ficam subsumidos, como se fossem outras questões, que não éticas, o que não implica que não sejam vividos sem a consciência de tal e acabem por refletir e comprometer negativamente a qualidade da assistência, do vínculo de cuidado entre a equipe de saúde e os usuários, ou até no trabalho da equipe. Nas minhas pesquisas, quando trabalho com o objeto do perfil dos problemas éticos na atenção básica, tenho assumido como 'problema ético' o que os profissionais reconhecem como tal. Na deliberação moral, busco levá-los a problematizar situações com vistas a voltá-los para a inserção dos valores na clínica.

b) A descoberta: quando um caso clínico é descoberto como moralmente problemático. Há casos clínicos tão cotidianos, usuais, que não costumam interpor dificuldades aos profissionais, pois percebem-no sob seu domínio, e a decisão a tomar não tropeça em nada que lhe inquiete. O problema começa quando o caso, por conta de suas distintas dimensões, incorpora algo novo que o profissional descobre como conflitivo ou contraditório. Por exemplo, uma 
decisão inesperada do usuário, devido ao contexto no qual o paciente vive sua doença, à influência dois meios de comunicação na percepção dos riscos ou nas possibilidades de tratamento, a uma comunicação deficiente entre os serviços de saúde como o atraso nos resultados de exames. Para o profissional de Saúde, descobrir um caso clínico como moralmente problemático significa encontrar-se em uma situação que paralisa sua atividade prática e "martela" (Pose, 2009, p.82), sua consciência moral; implica perceber algo conflituoso, vendo-se impedido de atuar, continuar com seu trabalho diário.

Ao desvelar ou descobrir o problemático, sente-se como que deslumbrado, cegado, necessitado de ajuda, pois não sabe o que fazer, como agir. É como se sofresse uma "paralisia de sentido", da qual não se recupera até que alguém ou algo venha em seu auxilio (Pose, 2009, p. 82).

c) As saídas morais; é próprio do caso clínico moralmente problemático apresentar-se com várias saídas, cursos de ação, incompatíveis ou que não se tenha claro por qual optar. Saída ou curso de ação é a possível resposta ou solução ao caso clínico eticamente problemático.

Cada curso de ação equivale a distintas opções de valores e as contradições entre os cursos correspondem ao conflito de valores. Esse momento, quando não sabemos por onde ir é o ponto para pôr em andamento o processo deliberativo, para parar, com vistas a não se precipitar, lançando mão de um procedimento para analisar a situação (Pose, 2009). Esse procedimento é o método deliberativo que nos levará a perceber o devemos fazer na situação.

Como o método deliberativo, o profissional de saúde poderá verificar a consistência do problema, ou seja, ver se, de fato, está diante de um problema rela ou se identificou mal o problema (Pose, 2009).

Lembremos que "problema ético" é um conflito de valores. Ao identificarmos os valores em conflito, ganhamos prudência na tomada de decisão, pois as decisões prudentes são as que salvam, ao máximo possível, os valores em conflito. Se não identificamos os valores e nos precipitamos em optar por uma saída sem análise prévia, corremos o risco de lesar um valor que não havíamos descoberto na situação (Pose, 2009). 
E o risco de uma solução trágica é considerável, já que as soluções extremas são as mais facilmente perceptíveis e essas salvam um (ou vários) valor em detrimento de outro (ou outros). Nosso dever é salvar, ou lesar o menos possível, todos os valores envolvidos no conflito. Para salvar os valores é preciso identificá-los.

Trata-se, então, de clarificar o que há por trás das saídas morais que se apresentam. Em uma situação de incerteza, quando não sabemos o que fazer, ver as saídas possíveis não é suficiente para uma decisão prudente (Pose, 2009). Sem identificarmos os valores, podemos parar as saídas extremas, sendo que as prudentes costumam ser as intermédias.

Pose, (2009), traz a situação de um paciente que se nega à transfusão de sangue por conta de suas crenças religiosas, como exemplo. Assinala o autor que, nessas situações, a equipe percebe como saídas: fazer a transfusão à força para salvar o paciente ou respeitar sua decisão e deixá-lo morrer. Nenhuma delas é prudente, mas, se não identificamos os valores que estão por trás de cada uma, não conseguiremos ver outras saídas possíveis. De um lado estão os valores "saúde" e "vida", pelos quais os profissionais de saúde querem sempre optar. Do outro, em conflito, está o "respeito à vontade do paciente". Se optarmos por salvar os valores "vida" e "saúde", fazendo a transfusão à força (ainda que às escondidas do próprio paciente), lesaremos totalmente o valor "respeito à vontade do paciente". E se optarmos pelo "respeito à vontade do paciente" e não fizermos a transfusão, lesaremos "vida" e "saúde", o que costuma ser bastante angustiante para os profissionais de saúde na clínica. Como vemos, as saídas encontradas, em primeiro lugar, usualmente, são dilemáticas, portanto pouco aconselháveis ou prudentes, por serem muito lesivas para alguns dos valores em conflito, uma vez que, para salvar totalmente um valor, acabamos lesionando completamente o oposto, o que pode terminar em tragédia. Isso seria imprudente. Temos que tentar evitar as soluções trágicas, e é trágico optar por um valor lesionando completamente outro, sobretudo quando o valor lesionado por completo é a vida. No exemplo, se o clínico opta por respeito de modo absoluto à vontade do paciente, no fundo pode estar permitindo sua morte, e o paciente, na verdade, não quer morrer, só quer que não Ihe transfundam, porque isso é contra suas crenças e 
seus valores. A solução prudente, então, passa pela busca de saídas intermédias, que são as que lesam menos os valores conflituosos.

Esses cursos de ação intermédiários somente podem ser vislumbrados por meio da análise minuciosa, cuidadosa, do problema concreto, ou seja, cada problema moral concreto requer sempre o mesmo procedimento, o mesmo esforço, igual empenho de análise. Não há uma regra para a conversão de um problema moral em um curso ótimo de ação. Os cursos ótimos podem ser vários e todos igualmente prudentes, sendo que o bom funcionamento da deliberação depende da criatividade e da capacidade deliberativa (de habilidades e competências deliberativas) dos profissionais envolvidos na situação; nenhum método por si só resolve um problema ético. O método é apenas um recurso, um instrumento para ajudar a ordenação de nossas ideias a partir de uma série de passos, mas que não resolvem automática e mecanicamente os conflitos (Pose, 2009).

A sensibilidade moral, que La Taille, (2006), define como a "capacidade de perceber questões morais em situações nas quais elas não aparecem com toda clareza" (p.87-88), ou, ainda, como "a capacidade de perceber dimensões morais de certas ações ou situações nas quais essas não aparecem com evidência" (p.88), é essencial na deliberação. É essa sensibilidade que precisa ser despertada nos profissionais da atenção básica, porque as situações sutis de conflitos morais próprios desse âmbito da assistência requerem uma atitude que La Taille, (2006), descreve como certa disposição de analisar com mais cuidado o ocorrido e uma certa fineza de pensamento, que permita ultrapassar o aparente, lendo nas entrelinhas, interpretando sinais, percebendo a sensibilidade alheia, seus motivos de alegria e sofrimento.

\subsection{ITINERÁRIO DA DELIBERAÇÃO}

Sinal de bom funcionamento da deliberação é quando as opiniões mantidas pelos participantes no ponto de partida são diferentes das que sustentam ao final do processo. Entretanto, este não é o único resultado 
decorrente do diálogo empreendido no processo deliberativo. Contam, ainda, haver sabido escutar a história dos outros com atitude empático-crítica; ter sido possível articular convicções coletivamente; haver aprendido a dialogar se autoregulando; haver escutado os demais, deixando-se interrogar. Assim, promovem-se atitudes e habilidades essenciais para relação das equipes e destas com os usuários dos serviços, como a capacidade para se por no lugar dos demais; considerar as diferentes perspectivas implicadas nas situações; aceitar a busca coletiva de soluções; argumentar coletivamente. Mais que se defender do outro, os envolvidos no diálogo aprendem um com o outro (Dordoni, 2007).

A deliberação moral é um método, um procedimento com fases pelas quais tem de passar o processo deliberativo, a análise crítica do caso em uma sessão de deliberação que pode ter lugar, por exemplo, em comitês e comissões de bioética ou em reuniões das equipes de saúde. Os passos do método da deliberação, esquematicamente, são:

\begin{tabular}{|l|l|}
\hline Deliberação sobre os fatos & $\begin{array}{l}\text { 1.apresentação do caso } \\
\text { 2. esclarecimento dos fatos do caso }\end{array}$ \\
\hline Deliberação sobre valores & $\begin{array}{l}\text { 3. identificação dos problemas morais } \\
\text { do caso } \\
4 . \text { indicação do problema moral } \\
\text { fundamental } \\
5 . \text { identificação dos valores em } \\
\text { conflito }\end{array}$ \\
\hline Deliberação sobre os deveres & $\begin{array}{l}6 . \text { identificação dos cursos de ação } \\
\text { extremos } \\
7 . \text { identificação dos cursos de ação } \\
\text { intermediários } \\
8 . \text { identificação do curso de ação } \\
\text { ótimo }\end{array}$ \\
\hline Deliberação & as aplicação das provas de \\
responsabilidades & $\begin{array}{l}\text { consistência ao curso de ação ótima: } \\
\text { tempo, publicidade e legalidade } \\
10 . \text { decisão final }\end{array}$ \\
\hline
\end{tabular}


I) Deliberação sobre os fatos

1. Apresentação do caso: a história clínica é o suporte documental do problema ético que vai ser analisado e deve se explorar o diagnóstico (o que ocorre), o prognóstico (o que poderá ocorrer) e o tratamento (alternativas terapêuticas). Entretanto é essencial que a apresentação da problemática amplie a clínica, focando os aspectos relativos às condições sociais, familiares, culturais, educacionais, religiosas e outros pontos necessários para compreender e problematizar a situação em seus aspectos éticos.

2. Esclarecimento dos fatos do caso: Após a apresentação do caso, abre-se um espaço para perguntas que serão dirigidas, pelos participantes da sessão de deliberação, a quem apresenta o caso. Não é para "julgar" o caso. O que se quer é entendê-lo o mais claramente possível, abrangendo, de maneira compreensiva, o que está acontecendo.

II) Deliberação sobre os valores

3. Identificação dos problemas morais: listam-se todos os problemas morais que os participantes percebam no caso. O problema é sempre uma dificuldade, uma dúvida. Uma boa maneira de enunciar os problemas morais é por meio de perguntas, formuladas em linguagem precisa, clara e sem uso de jargões recomenda-se evitar questões binárias, que levem a respostas do tipo sim/não. Quanto mais localizada e precisa for a pergunta, mais fácil será encontrar os valores em conflito e a resposta que buscamos na deliberação.

4. Indicação do problema moral fundamental: dentre os problemas identificados no passo anterior, elege-se o que será alvo de deliberação. Como não é possível analisar todos os problemas morais enumerados, o melhor é indicar um ou dois fundamentais para seguir a deliberação. É útil que identifiquemos mais de sete e menos de quatorze "questões problemas", para não sermos nem muito reduzidos e tampouco repetitivos, isso possibilitará encontrar os problemas que são, verdadeiramente, conflitos de valores.

5. Identificação dos valores em conflito: neste momento é que se verificará se o problema eleito corresponde, de fato, a um conflito de valores. Somente os conflitos de valores podem ser alvo da deliberação. Para identificar os valores em conflitos, é preciso colocar-se no lugar de quem apresenta o 
caso, tentando ver o que a pessoa sente, vive, ou seja, o conflito de valores que experimenta.

III) Deliberação sobre os deveres

6. Identificação dos cursos de ação extremos: etapa de sugestões de alternativas de solução, dos cursos de ação, para o manejo do caso. Trata-se de deliberar sobre o que devemos fazer para realizar os valores, tentando buscar todas as saídas possíveis para, dentre estas, eleger a ótima, a que realiza todos os valores em conflito sem lesar nenhum. Isto porque o método da deliberação, como proposto por Diego Gracia,(1998), entende que o nosso dever ético é realizar valores.

7. Identificação dos cursos de ação intermédios: é neste passo que fica patente a racionalidade problemática que embasa o método da deliberação, ou seja, o modo problemático de interpretar e lidar com os conflitos de valores que permite enxergar outras saídas além das duas polares e extremas. Enxergar de maneira míope e reduzida somente estas duas alternativas opostas e extremas é próprio da racionalidade dilemática, que é imprópria à deliberação.

8. Identificação do curso de ação ótimo: é o momento de eleger o melhor curso de ação para resolver ou lidar com o caso. Lembre-se de que um problema ético pode não ter solução, mas isso só poderá ser percebido ou concluído depois de percorrer o processo de deliberação. É quando se busca o ótimo, pois a ética almeja o ótimo, não se contenta com o bom. O curso de ação ótimo é o que lesa, em menor grau, todos os valores em conflito. Isto é, o ótimo é o que realiza todos valores.

IV) Deliberação sobre as responsabilidades

9. Aplicação das provas de consistência: consiste em submeter o curso de ação ótima a uma comprovação de sua consistência por meio das provas: (a) Legalidade (essa decisão é legal?); (b) Publicidade (estaria disposto a defender publicamente a decisão tomada?); e (c) Temporalidade (tomaria a mesma decisão se tivesse mais tempo para decidir?). Estas provas visam garantir que a decisão que se vai tomar seja prudente e responsável.

10. Decisão final: a decisão final é responsabilidade de quem apresenta o caso, de quem pediu a ajuda da instância de deliberação. 


\section{OBJETIVOS}

\subsection{OBJETIVO GERAL}

Analisar o impacto de uma ação educativa em bioética clínica e deliberação moral aplicadas à atenção básica, a saber: se a percepção de problemas éticos se modificou; se contribui com aportes para lidar com as questões éticas na prática.

\subsection{OBJETIVOS ESPECÍFICOS}

> Comparar o perfil de problemas éticos antes e depois de participarem de ação educativa problematizadora em bioética clínica e deliberação moral, aplicadas à atenção básica.

> Discutir, segundo a visão dos educandos, a utilidade de uma ação educativa problematizadora, para sua prática profissional na ESF.

> Discutir, a partir da opinião dos educandos, a adequação do enfoque problematizador para ações educativas em bioética clínica e deliberação moral. 


\section{METODOLOGIA}

\subsection{TIPO DE ESTUDO}

Pesquisa qualitativa que configurou com estudo de intervenção do tipo antes e depois (Gutierrez, 2004).

Além da pesquisa de Gutierrez (2004) para a escolha do tipo de estudo, pautamos-nos nas contribuições de Rimoni (2003), que desenvolveu pesquisa quantitativa para analisar o impacto de uma intervenção pedagógica na assistência e gestão dos serviços de saúde.

Nas pesquisas de intervenção do tipo antes e depois, recorta-se o cotidiano em suas tarefas, em sua funcionalidade, em sua pragmática. Buscase uma mudança resultante da produção de uma nova relação entre teoria e prática, sujeito e objeto, a partir dos conflitos e tensões que se apresentam como possibilidades de mudança ao demonstrarem que algo não se ajusta, ou está fora da ordem (Aguiar, Rocha, 2003).

A intervenção pedagógica, no presente estudo, foi uma ação educativa em bioética clínica e deliberação moral aplicadas à atenção básica.

A fundamentação da intervenção pedagógica na bioética deliberativa e no enfoque problematizador foi feita porque, além das tarefas e funções, almejávamos mudanças atitudinais, ou seja, éticas, nos próprios participantes. Assim, concordando com Rimoni (2003), apostamos, em uma postura de "nãoneutralidade"; na necessidade de ser mais propositiva; no reconhecimento da riqueza das interações; no manejo relacional entre educador e educando; na valorização do trabalhador do SUS. 


\subsection{A INTERVENÇÃO PEDAGÓGICA: UMA AÇÃO EDUCATIVA EM BIOÉTICA CLÍNICA E DELIBERAÇÃO MORAL APLICADAS À ATENÇÃO BÁSICA}

Foi proposta uma ação educativa para os profissionais de saúde que atuam na atenção básica do SUS, especialmente os enfermeiros e médicos. Assim consideramos as peculiaridades da prática profissional e da assistência neste âmbito do sistema de saúde, bem como as propostas de políticas publicas para sua humanização. A partir de noções de bioética, apresentamos e propusemos o método deliberativo como forma de: (a) desenvolvimento e integração de uma base de conhecimentos e habilidades em bioética por meio de um processo de autoeducação, quase autoanalise, que propiciou a transformação da prática profissional a partir da incorporação de valores que resultem em mudanças atitudinais; (b) interpretação de dados e estabelecimento de conexões de sentido que permitiram identificar e abordar os conflitos éticos que surgem no trabalho diário, com vistas a melhorar a qualidade e a humanização da assistência; (c) propiciar, a partir de uma situação clínica, a ponderação e inclusão dos valores e aspectos contextuais que concorrem para situação vivida pelo usuário, sua família e a equipe de saúde, melhorando a compreensão das vivências e experiências; (d) levar os profissionais a mudanças atitudinais, num compromisso responsável com excelência moral e técnica de sua prática profissional e da assistência que prestam.

Os objetivos a ação educativa em bioética eram:

- proporcionar conhecimentos de bioética que permitissem aos profissionais de saúde a análise sistemática e crítica dos aspectos éticos de sua prática na atenção básica, considerando as peculiaridades desse âmbito da assistência;

- subsidiar o processo de tomada de decisões frente a problemas éticos na atenção básica, a fim de que os profissionais fossem capazes de argumentar de maneira precisa e consistente acerca de suas eleições nestas situações; 
- desenvolver as habilidades necessárias para a deliberação moral frente a problemas éticos na atenção básica, propiciando juízos prudentes, refletidos, ponderados e que permitissem a argumentação e contra-argumentação; num verdadeiro diálogo da equipe.

Visava, com a ação educativa, desenvolver as seguintes competências e habilidades:

- incorporar na prática clínica os saberes e habilidades da bioética e deliberação moral;

- diferenciar a especificidade da bioética, distinguindo-a do direito e da deontologia profissional;

- perceber os problemas éticos e os conflitos de valores que subjazem a prática profissional cotidiana na atenção básica;

- integrar fatos, valores e deveres no processo de deliberação para ser capaz de argumentar suas decisões;

- aplicar os passos do método de deliberação moral na análise compreensiva dos problemas éticos para chegar a decisões consistentes e argumentadas do ponto de vista moral;

- operar com a racionalidade problemática na identificação de cursos de ação intermediário e o ótimo na deliberação moral;

- descrever de maneira clara e precisa os problemas éticos e os cursos de ação;

- identificar, dentre os problemas éticos, quais correspondem a conflitos de valores e que podem, portanto, ser alvo de deliberação moral;

- nomear com precisão os valores em conflito nos problemas éticos;

- perceber a importância de saber manejar habilidades de comunicação e escuta na deliberação dos problemas éticos;

- compreender que nem sempre é possível solucionar um problema ético;

- conviver respeitosamente e dialogar com visões morais distintas das próprias; 
- reconhecer os conflitos morais no trabalho em equipe, sendo capaz de manejá-los pela deliberação;

- estar atento para suas necessidades de capacitação e aprimoramento em bioética, comunicação terapêutica, relação de ajuda, escuta empática e outros temas correlatos que possam mediar a deliberação moral.

Para isso, o conteúdo programático, desenvolvido transversalmente nas sequências de atividades, incluiu:

I. Bioética: gênese, trajetória, concepções e abrangência temática

1.1 Moral, Ética, Ética profissional, Direito e Bioética: pontos em comum e especificidades destas diferentes linguagens

II. Fundamentação da bioética

2.1. A experiência ética: o nível dos valores e do deveria

2.2. A experiência moral: o nível dos valores e do deveres

2.2.1. A dimensão intelectual da experiência moral: o saber fazer

2.2.2. A dimensão afetiva da experiência moral: o querer fazer

2.3. Momentos de análise do ato moral: integrando as experiências ética e moral

2.3.1. Os fatos

2.3.2. Os valores

2.3.3. Os deveres

2.4. O risco dos reducionismos: as falácias

2.5. A virtude da prudência

2.6. A responsabilidade moral na prática clínica

III. A deliberação como método para a bioética

3.1. Problema e dilema ético: duas racionalidades distintas

3.2. Delimitação de um problema ético: o conflito de valores

3.2. O processo de deliberação e os procedimentos para a análise do caso

IV. Peculiaridades da Atenção Básica e as implicações para a bioética e a deliberação moral

4.1. Clínica ampliada, bioética amplificada

4.1.1. Ética na relação clínica

4.1.2 Ética nas relações de equipe 
4.1.3. Os benefícios da mediação das técnicas de entrevista clínica, da relação de ajuda, do suporte emocional e da comunicação terapêutica.

4.2. Os problemas éticos na atenção básica: características, perfil e abrangência.

Os conteúdos foram trabalhados de maneira transversal em sequências de atividades, com dois momentos de concentração e uma dispersão.

A carga horária total foi de 40 horas, sendo $30 \mathrm{em}$ atividades de concentração, distribuídas em dois momentos: uma semana inicial de 20 horas para as sequências de atividades e uma segunda semana, depois da dispersão, para aplicação do método da deliberação na análise de casos. As atividades de dispersão completaram 10 horas e foram feitas nas duas semanas que se seguiram ao primeiro momento de concentração. Incluíram: exercícios para aplicação do método de deliberação em casos hipotéticos apresentados pelo monitor, que deveriam ser entregues por escrito e serviram para avaliação do aprendizado; seleção de um caso vivido, no qual os profissionais julgassem haver vivido problemas éticos, para apresentação e deliberação na plenária do grupo. Essa atividade foi realizada em trios de participantes: um para apresentação do caso, outro para a moderação da sessão de deliberação e o terceiro que, como observador, devia avaliar o desempenho do grupo no itinerário de deliberação.

Como recursos didáticos nas sequências de atividades foram usados: leitura e discussão crítica de textos; dramatização e jogos dramáticos; aulas síntese; discussão em grupo e plenárias; análise de casos; instrumento para avaliação de problemas éticos na atenção básica; apresentação de casos para análise. 


\subsection{DESENHO DO ESTUDO}

O estudo teve o desenho que segue na representação esquemática

Figura 2 Representação esquemática do estudo

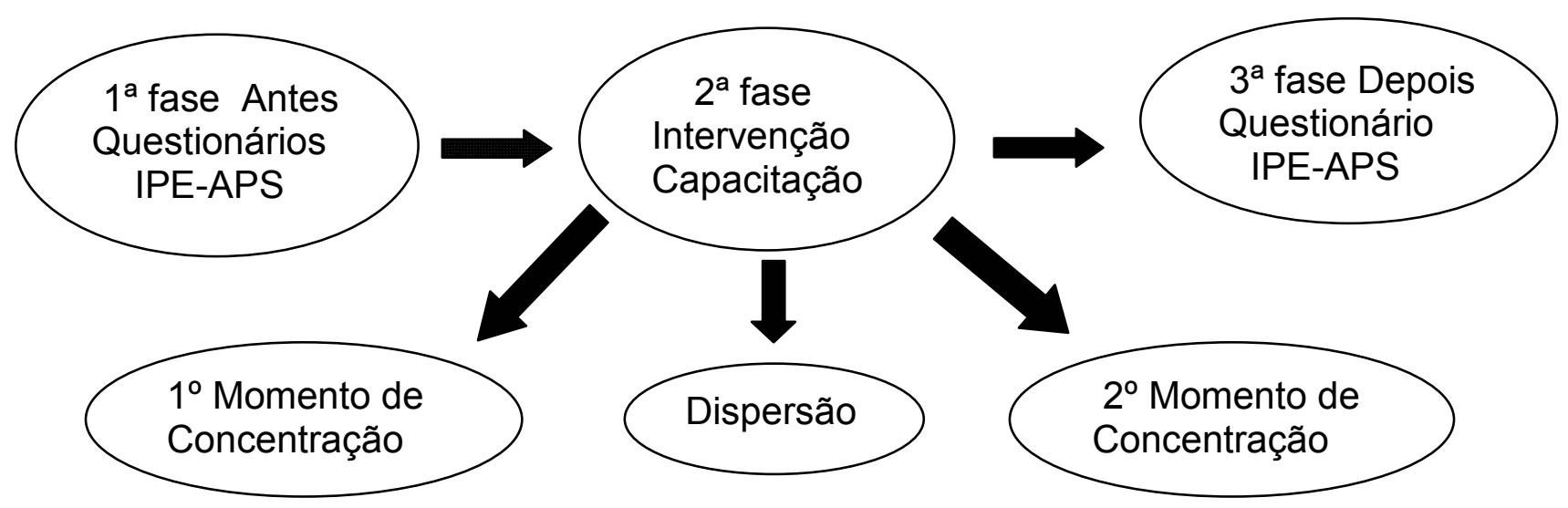

Para avaliação das mudanças nas percepções dos problemas antes e depois da ação educativa, foi aplicado um investimento, validado por Silva (2006) e Amado (2010), chamado Inventário de Problemas Éticos na Atenção Primária à Saúde (IPE-APS Anexo $A$ )

O IPE-APS foi aplicado em três momentos:

1 - antes da ação educativa;

2 - no fim do primeiro momento de concentração;

3 - no fim do segundo momento de concentração, ou seja, ao final da ação educativa como um todo.

Para avaliar os aportes da ação educativa para lidar com questões éticas na atenção básica, aplicamos três questões abertas, que foram respondidas por escrito:

> O que você aprendeu durante as sessões de deliberação do curso?

$>$ Do que você sentiu falta durante as sessões de deliberação do curso?

> Como esse curso sobre bioética e deliberação moral influenciará sua prática nos trabalho diário? 
Em resumo, o estudo incluiu a aplicação de uma proposta de capacitação no método de deliberação moral, a partir da pedagogia da problematização. A ação educativa foi efetivada através de um facilitador, especialista em bioética e no método da deliberação, que havia concebido a proposta de capacitação. As reuniões na primeira semana de concentração consistiram, basicamente, na reflexão sistematizada com profissionais de saúde sobre questões morais que surgem dentro de casos clínicos ou situações assistenciais próprias da atenção básica. O principal propósito era desconstruir a ideia de ética como "certo e errado" e apresentar a compreensão da bioética deliberativa, que trata das decisões prudentes e responsáveis.

As discussões sobre os casos levavam, em média, 45 minutos por meio de uma conversa direcionada, com métodos selecionados para atender a metas específicas. (A sequência de atividades encontra-se no anexo B)

Para a realização da ação educativa, foi realizado contato junto ao Departamento de Assistência á Saúde (DAS) da Secretaria de Saúde do município de Santo André, para verificar a viabilidade da proposta e do estudo. A diretoria do DAS mostrou-se receptiva à temática das questões éticas e à contrapartida, que incluía a certificação da capacitação pela Escola de Enfermagem da Universidade de São Paulo, já que o curso havia sido aprovado pela Comissão de Cultura e Extensão da Escola.

A realização da capacitação se deu de forma fechada e gratuita na Escola de Saúde Eduardo Nakamura, equipamento pertencente à Secretaria de Saúde do município de Santo André, local destinado á capacitação dos profissionais. A oferta do espaço e dos recursos para tal foi a contra-partida do Município.

A Escola de Saúde se localiza na região central da cidade, facilitando o acesso dos participantes Possui salas amplas, com boa ventilação e luminosidade, quadro-branco e audiovisual (televisão e DVD Player). O projetor de multimídia foi cedido pelo Ambulatório de Referência de Moléstias Infecciosas (ARMI), uma vez que o aparelho da Escola de Saúde estava danificado. Visando à confraternização, bem como intervalo de tempo para assimilação dos conteúdos, foi oferecido coffe-break patrocinado pela mestranda. 
Para a reserva da sala no espaço foram seguidas todas as normas da Prefeitura de Santo André, com o preenchimento das requisições próprias, descrição do curso, número de participantes e os horários.

\subsection{CENÁRIO DO ESTUDO}

O cenário utilizado para o estudo foi constituído por profissionais de saúde, entre eles médicos e enfermeiros da ESF do município de Santo André.

Segundo dados do anuário de 2009 da Prefeitura do Município de Santo André (PMSA), localizado na região do Grande ABC Paulista, que faz divisa com São Paulo e abriga 07 cidades caracterizadas pelo polo produtivo industrial, comercial e de serviços.

Santo André possui uma área de $174,38 \mathrm{~km}^{2}$, distribuídos em $66,45 \mathrm{~km}^{2}$ de áreas urbanas e $107,93 \mathrm{Km}^{2}$ representados por áreas de proteção ambiental.

A população estimada do município, em 2008, segundo o IBGE, totaliza 661.353 habitantes, distribuídos em 185.370 habitações; destes, 51,7\% pertencem ao sexo feminino e $48,3 \%$ ao sexo masculino. A expectativa de vida é de 76 anos; a densidade demográfica é de 3,85 hab./km e possui crescimento vegetativo anual da ordem de 0,61\% (IBGE, 2005).

A faixa etária em que se concentra o maior número de pessoas é de 40 a 49 anos, com 14\%; seguida da faixa de 20 a 29 anos, com 9,5\%. Nas faixas restantes, a média é de $8 \%$, com exceção das faixas acima de 60 anos, em que a média é de 5\%; e da faixa das pessoas menores de 09 anos, que é de 7\% (Santo André, 2009).

Destaca-se que $98 \%$ da população total do município é atendida pela rede de abastecimento de água fluoretada e esgoto, segundo dados do SEMASA - Serviço Municipal de Saneamento Ambiental de Santo André. O município é atendido por coleta de lixo em 99,3 do território e o percentual de iluminação pública é de $98 \%$ (SEADE, 2004). 
A População Economicamente Ativa (PEA) é de 360.345.Em 01/01/2009 encontravam-se formalmente empregados 169.789 pessoas, segundo dados do Ministério do Trabalho e Emprego (Santo André, 2009).

Os principais eixos viários são: o Anel Viário Metropolitano, a Estrada de Ferro Santos-Jundiaí e o Rodoanel.

Está previsto para Santo André, no período 2007/2010, um fluxo de investimento do Programa de Aceleração do Crescimento - PAC, do Governo Federal, da ordem de $\mathrm{R} \$ 293,0$ milhões em saneamento e habitação. O Produto Interno Bruto (PIB) é de R $\$ 11,7$ bilhões (2006), segundo o IBGE. Este é o $24^{\circ}$ maior PIB municipal do país e o $9^{\circ}$ do Estado de São Paulo.

O Indicador de Potencial de Consumo (IPC), mensurado pela Target Marketing (2009) para Santo André, somou R\$ 5,8 bilhões, constituindo o $5^{\circ}$ maior potencial de consumo do Estado de São Paulo e o $15^{\circ}$ maior do Brasil. Todo este potencial advém da geração de riqueza e consequentemente da geração de emprego e renda, que se reverte na extensão do mercado local, dinamizando a atividade econômica (Santo André, 2009).

A indústria é responsável por $22,97 \%$ do total dos empregos. Neste setor, as atividades que mais empregam são as indústrias metalúrgicas e as químicas. O setor de comércio responde por $20,40 \%$ do total de empregos, com destaque para o comércio varejista, com mais de 30.000 empregados. As empresas de micro e pequeno porte, com até 100 empregados, respondem por $45,63 \%$ dos empregos formais existentes, destacando-se como importante fonte de geração de trabalho e renda (Santo André, 2009).

De acordo com os dados da RAIS 2007, a maioria dos empregados formais no Grande $\mathrm{ABC}(67,66 \%)$ possui renda entre um e quatro salários mínimos. Isoladamente, esta situação não é muito diferente nos municípios, sendo que, em Santo André, 72,20\% dos empregos formais estão na mesma faixa de renda acima (Santo André, 2009).

O ensino fundamental conta com uma rede de 44 escolas municipais, 91 escolas estaduais e 74 escolas particulares, com 7.382 alunos, 56.399 alunos e 20.634 alunos matriculados, respectivamente (Santo André, 2009).

No ensino médio, há 54 escolas estaduais e 27 particulares, com 23.965 e 4.550 alunos matriculados respectivamente (Santo André, 2009). 
São oferecidos no município 24 cursos técnicos, com três escolas públicas de ensino técnico-profissionalizante. Reúne 14 das 38 instituições de ensino superior da Região, com destaque para a Universidade Federal do ABC.

Segundo o Índice de Desenvolvimento Humano (IDH) do município, medido pela educação (IDH-E), longevidade (IDH-L) e renda (IDH-R), Santo André apresenta um IDH de 0, 836 em uma escala de 0 a 1, indicando um desenvolvimento humano bastante alto ocupando a posição de $23^{\circ}$ no ranking dos 645 municípios paulistas (Santo André, 2009).

Ao avaliar os aspectos socioeconômicos da cidade têm-se o objetivo de aferir e de mostrar sua dinâmica econômica e seus efeitos. Responsável pelo fluxo de geração de riqueza no município, a dinâmica socioeconômica reflete impactos sociais advindos das flutuações da atividade produtiva. Por isso, selecionamos indicadores que apresentam o fluxo produtivo do município, a inserção da economia local no setor externo e o comportamento do mercado de trabalho.

As ações de saúde, bem como a distribuição de serviços e metas propostas no Plano Municipal de Saúde, pautam-se pelos princípios do SUS (Sistema Único de Saúde) - Universalidade, Integralidade, Descentralização, Comando Único, Participação Social e pelas diretrizes para o quadriênio 20042008: Acesso e Qualidade, Humanização, Eficiência Gerencial e Participação Popular (Santo André, 2009).

A rede municipal de saúde é organizada hierarquicamente em serviços com a seguinte disposição:

- 01 Hospital Municipal com 331 leitos;

- 01 Hospital da Mulher Municipal;

- 04 Unidades de Pronto Atendimento;

- 14 Unidades Básicas de Saúde;

- 08 Unidades de Programa de Agente Comunitário de Saúde;

- 11 Equipes de Estratégia de Saúde da Família;

- 09 Serviços Especializados e de Referencia;

- 08 Serviços de Saúde Mental. 
Das internações realizadas no hospital municipal 45,3\% ocorreram em clínica médica, seguida por 23,2 em clínica cirúrgica. Das ações realizadas pela USF temos um total de 648.802, que corresponde a $35 \%$ das ações realizadas na atenção básica; destes, 46\% foram procedimentos clínicos e $37 \%$, ações de promoção e prevenção à saúde (Santo André, 2009).

Segundo Santo André 2009, o município possui 47.458 famílias cadastradas no PSF.

Foram realizadas 320.067 visitas domiciliares; destas 0,7\%, por médicos; 2,2\%, por enfermeiros; 2,5\%, por auxiliares de enfermagem; 94,6\%, por agentes comunitários de saúde. Foram realizadas 614.494 consultas nas Unidades de saúde, 582.530 atendimentos no programa de agentes comunitário de saúde, 661353 atendimentos realizados pelo programa d e saúde da família (Santo André, 2009).

O PSF de Santo André, foi implantado em 1998, visa propiciar assistência integral à saúde, de boa qualidade, através do atendimento personalizado, atuando na promoção, prevenção, diagnóstico precoce, tratamento e recuperação da saúde, contribuindo para melhoria da qualidade de vida da população. É composto por 39 equipes contando com 29 médicos e 37 enfermeiros.

\subsection{SUJEITOS DO ESTUDO}

Participaram do estudo sete médicos, sete enfermeiros e um odontólogo, trabalhadores da ESF da Prefeitura de Santo André.

Dos sete enfermeiros, uma desistiu; assim, não foi incluída na avaliação, porque não preencheu os três momentos de aplicação do IPE-APS.

Dos sete médicos, uma não participou do segundo momento de concentração. 
A odontóloga ${ }^{2}$ foi incluída por ter manifestado interesse pelo tema, embora não fosse parte da população planejada para a pesquisa. Por esse motivo e por não ter respondido o IPE-APS ( $3^{\circ}$ momento), não foram incluídos seus dados.

Assim, os dados incluídos nos resultados referem-se a 12 sujeitos, sendo seis enfermeiros $(50 \%)$ e seis médicos $(50 \%)$ que concluíram a ação educativa e atenderam a totalidades dos requisitos definidos para a metodologia do estudo.

$\mathrm{Na}$ categoria profissional médico, os sujeitos se dividiram igualmente entre os dois sexos. A faixa etária média foi de trinta e dois anos; a média do tempo de formado foi de seis anos e a do tempo de atuação na ESF foi de cinco anos (tabela 1)

Tabela 1 - Perfil demográfico da amostra de médicos - Santo André - 2010

\begin{tabular}{lcc}
\hline \multicolumn{1}{c}{ Características } & N & $\%$ \\
Sexo & 03 & 50 \\
Masculino & 03 & 50 \\
Feminino & 06 & 100 \\
Total & & \\
Idade & $24-46$ & \\
Variação & & \\
Ano de graduação & $1984-2009$ & \\
Variação & & \\
Atuação na ESF & $1984-2010$ & \\
Variação &
\end{tabular}

Fonte: dados primários

$\mathrm{Na}$ categoria profissional enfermeiro, a pesquisa contou com $84 \%$ participantes do sexo feminino (05) e $6 \%(01)$ do sexo masculino. A faixa etária média foi de vinte e oito anos; o tempo médio de formado foi de sete anos e o de atuação na ESF, quatro anos (tabela 2).

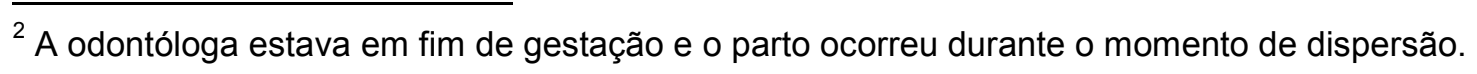


Tabela 2 - Perfil demográfico da amostra - enfermeiros - Santo André - 2010

\section{Características}

\section{Sexo}

Masculino

Feminino

Total

Idade

Variação

Ano de graduação

Variação

$$
2000-2004
$$

\section{Atuação na ESF}

Variação

\section{N}

01

05

06

$26-40$
$\%$

Fonte: dados primários

\subsection{ASPECTOS ÉTICOS}

O projeto de pesquisa seguiu as diretrizes da Resolução n 196/96 e foi aprovado pelo Comitê de Ética da Prefeitura Municipal de Santo André (Anexo C).

Aos participantes foi esclarecido que a participação na pesquisa era voluntária, não remunerada, entretanto, sem prejuízos salariais, uma vez que havia liberação do Departamento de Assistência a Saúde (DAS) para participação na capacitação.

Garantiu-se liberdade de participação, de recusa e de retirar-se do estudo a qualquer momento, sem prejuízo algum. Ou seja, se o participante não quisesse participar da pesquisa, ainda assim, poderia participar da capacitação para a qual já estava liberado de suas atividades na UBS. Foi garantido também o sigilo de suas identidades nas publicações e divulgações dos resultados.

A participação se efetivou após a ciência do Termo de Consentimento Livre e Esclarecido (Anexo D), elaborado de acordo com as determinações da 
Resolução CNS/MS 196/96 e assinado pelos entrevistados. O Termo também foi assinado também pelo pesquisador responsável. Cada participante recebeu uma cópia do termo, e uma outra via ficou com o pesquisador responsável.

Constou do termo: os objetivos da pesquisa, permissão para publicação e garantia de sigilo e confidencialidade, além de outras formas de segurança previstas na Resolução CNS/MS 196/96.

\subsection{ORGANIZAÇÃO E ANÁLISE DOS DADOS}

Os problemas identificados nos três momentos de aplicação do IPE-APS foram comparados não com intuitos de descrições quantitativas e associativas da mudança de percepção das questões éticas, mas em corte qualitativo. Os dados foram organizados por problemas, por categoria profissional.

Esta apreciação da mudança nas percepções das questões éticas foi enriquecida com as anotações do diário de campo, onde se registraram as situações observadas durante a capacitação, especialmente as impressões dos pesquisados e outros fatos relevantes. $O$ objetivo foi $\mathrm{o}$ de compreender $\mathrm{O}$ conjunto de significados, ações, valores e atitudes relacionados a temática proposta pelo estudo.

O diário de campo é o relato escrito daquilo que o investigador ouve, vê, experiencia e pensa no curso da coleta de dados. Tem características descritivas, com descrição do espaço físico e descrição de atividades; e características reflexivas, como o método utilizado, conflitos e dilemas e o ponto de vista do observador (Bogdan, Biklen, 1994).

As questões abertas, aplicadas aos participantes para avaliar a utilidade e adequação da proposta ao seu trabalho nas unidades de saúde, foram organizadas com análise de conteúdo, que, segundo Bardin (1977, p.42).

\footnotetext{
Um conjunto de técnicas de analise de comunicação visando obter, por procedimentos sistemáticos e objetivos de descrição do conteúdo das imagens, indicadores (quantitativos ou não) que permitem a inferência de conhecimentos relativos às condições de produção/recepção destas mensagens.
} 


\section{RESULTADOS}

\subsection{PROCEDIMENTOS PARA REALIZAÇÃO DA AÇÃO EDUCATIVA}

\subsubsection{Como transcorreu a ação educativa}

A capacitação transcorreu em um clima de tranquilidade, apoio e acolhida. A maior parte dos participantes já se conhecia, por serem integrantes da ESF. Todos se mostravam interessados e participativos, à exceção da enfermeira que acabou desistindo do curso antes do término da primeira semana de concentração.

Durante o momento de parada para o intervalo (coffe-break), havia o compartilhamento de vivências e troca de conhecimentos.

No primeiro encontro, embora muitos se conhecessem, houve a apresentação dos participantes, pois ainda havia alguns profissionais que ainda não se conheciam (dois médicos e um enfermeiro). Além disso, também a mestranda e sua orientadora, que funcionaria como a facilitadora da capacitação, não eram conhecidas do grupo participante. Ocorreu também a apresentação dos conteúdos a serem trabalhados e da proposta de pesquisa que cercava a iniciativa da ação educativa. Após isso, os participantes procederam, individualmente, à leitura e preenchimento de termo de livre esclarecido. Não houve nenhuma recusa de participação.

Após o consentimento, aplicou-se o IPE- APS aos participantes, logo no primeiro momento do encontro.

O material didático foi separado, sendo distribuído a cada encontro somente o material correspondente ao tema a ser trabalhado naquele período.

Os participantes se mostravam interessados no tema da capacitação; liam o material entregue diariamente; apresentavam - se participativos, trazendo experiências vivenciadas em seu cotidiano; fomentavam a discussão em grupo 
sobre a temática, correspondendo bem à metodologia participativa da capacitação.

Alguns pontos abordados se destacaram e foram discutidos com maior aprofundamento: o olhar na perspectiva do usuário; identificação e reconhecimento dos problemas éticos no dia a dia; necessidade e utilidade de detectar as redes sociais existentes para aprimorar a assistência na $A B$, visando à integralidade; o diálogo entre os profissionais; o inventário de problemas e a percepção dos possíveis caminhos a serem percorridos em busca da melhor solução, com vistas a sair dos polos negativo e positivo do leque de possibilidades para condução das situações problemáticas (Anexo E).

A capacitação proposta trabalhou os temas de maneira a levar o discente à autoanálise, tendo sido testemunhados momentos de reconhecimento dos participantes por haverem analisado o fato em toda sua magnitude e que, se o tivessem feito, provavelmente, não teria tomado a atitude de resultados trágicos.

Como costuma acontecer na iniciativa socrática de ensino da bioética, os participantes se aproximaram, numa "amizade acadêmica e de vida". Demonstra isso que, por própria iniciativa, o grupo se cotizou para a realização de um café comunitário com intuito de marcar com uma confraternização o fechamento do primeiro momento de concentração e o início da dispersão. Essa confraternização foi realizada após o segundo preenchimento do IPEAPS. As fotos, onde se vê todos muitos felizes, foram circuladas no grupo por email.

Aliás, essa foi outra questão de união, por iniciativa própria, fizeram uma lista de emails para troca de textos, fotos, situações e comunicação posterior ao término da capacitação e da dispersão. 


\subsection{RESULTADOS E DISCUSSÃO}

\subsubsection{Resultados da aplicação do IPE-APS}

Na proposta do estudo utilizou-se o IPE-APS validado por Silva, 2006 e Amado, 2010, contendo 40 problemas éticos comuns à Atenção Básica (Atenção Primária à Saúde - APS), em três domínios: relações dos profissionais com os usuários; relações das equipes e relações com o sistema de saúde. Para inventariar com que frequencia os profissionais se deparam com os problemas listados, há uma escala nominal que marca se o profissional considera a situação apresentada como problema ético e, em caso positivo,quando o encontra: nunca, ocasionalmente ou comumente.

O IPE-APS disponibiliza ainda informações sobre categoria profissional, sexo, idade, tempo de formado e tempo de trabalho na ESF,

Os resultados incluem os três momentos de aplicação do IPE-APS: antes do início da capacitação; ao fim do primeiro momento de concentração e ao final da capacitação. Foram obtidos pela análise qualitativa da mudança no perfil dos problemas assinalados nos três momentos, complementando-se com as anotações do diário de campo. Muitas das situações apresentadas no IPEAPS mobilizavam comentários, falas, relatos, narrativas dos participantes. Isso foi anotado de maneira livre, pois o estudo propunha-se como qualitativo na observação das modificações da sensibilidade ética após a capacitação.

As tabelas 3 e 4 trazem o perfil dos problemas assinalados a cada rodada. Os resultados do momento inicial, antes do início da capacitação, estão na tabela 3; os demais, na 4.

Dois dos profissionais médicos não consideravam como problema ético no primeiro momento de aplicação do IPE-APS os seguintes problemas:

$>$ 02: Pré-julgamento dos usuários dos serviços por parte das equipes;

20: Usuários pedem a um dos membros da equipe para guardar segredo de algo sobre sua saúde e para não contar nada aos demais membros da equipe de PSF; 
> 27: Dificuldades e falta de referência para realizar exames complementares;

28: Dificuldades quanto ao retorno e confiabilidade dos resultados de exames laboratoriais.

Nos momentos de aplicação do Inventário que se deram durante e ao final da capacitação, os médicos passaram a reconhecer a situação como problema ético, indicando mudança na percepção de questões que são sutis, como pré-julgamento, ou que, embora possam ser questões administrativas ou gerenciais da organização dos serviços, acabam implicando questões éticas (realização e confiabilidade dos exames complementares).

O problema 22 (falta de apoio com ações intersetoriais para discutir e resolver problemas éticos) foi deixado em branco por um profissional nos três momentos de aplicação do IPE-APS durante a realização da capacitação.

A mudança mais expressiva na percepção dos participantes deu-se nas questões relativas à privacidade e confidencialidade. No momento inicial, dois participantes assinalaram "nunca" ter se deparado com a situação 11 (É difícil manter a privacidade do usuário nos atendimentos feitos em casa). Nas aplicações subsequentes, já identificaram a ocorrência dessa questão no seu cotidiano.

O mesmo se deu com as situações 21 (Dificuldades para preservar a privacidade por problemas de estrutura física e rotinas da USF) e 20 (Usuários pedem a um dos membros da equipe para guardar segredo de algo sobre sua saúde e para não contar nada aos demais membros da equipe de PSF). Como estas situações também referem-se à privacidade e confidencialidade no domínio das relações do profissional com o usuário, indica-se uma mudança na sensibilidade ética nesta questão. Em ambas, ainda se marca que a frequencia que os profissionais reconhecem se deparar com elas no seu trabalho muda, com menos "nunca" assinalados.

Sabe-se que a privacidade e confidencialidade dos usuários na ESF é um dos nós críticos dos aspectos éticos nas relações dos profissionais com os usuários.

A noção de respeito e de trato respeitoso no trabalho em equipe modificou-se. Dois participantes que assinalaram "nunca" para a situação 16 
(Falta de respeito entre os membros da equipe) no primeiro momento de aplicação do IPE-APS, passaram a assinalar "comumente" e "ocasionalmente" nos outros dois.

Outra mudança expressiva foi a percepção de que a tomada de decisão conjunta, compartilhada nas questões de conflitos éticos passa a ser vista como desejável, ou ao menos, passam a manifestar sua falta. A situação 22 (Falta de apoio com ações intersetoriais para discutir e resolver os problemas éticos) que foi assinalada como "nunca" por 05 participantes no primeiro momento, nos subsequentes não foi assinalada por nenhum dos sujeitos.

Parece que se mobiliza o equívoco entre ética e proteção corporativa. A situação 19 (Profissionais que se omitem diante de uma prescrição inadequada ou errada) que era assinalada como "nunca" encontrada no primeiro momento de aplicação do Inventário, passa a ocorrer somente para 03 nos outros dois momentos.

O pré-julgamento dos usuários muda em sentido inverso. No primeiro momento, um participante assinala a situação 2 (Pré-julgamento dos usuários dos serviços por parte das equipes) como "nunca"; no segundo momento, nenhum participante assinala "nunca", e no terceiro momento 05 o assinalam. O preconceito e as ideologias foram muito discutidos durante a capacitação e chama à atenção este resultado, pois se esperava despertar para a visão dos preconceitos que são influentes nas ações e decisões dos profissionais.

Esses resultados são, em consonância com o estudo, de cunho qualitativo. Assim, as mudanças, ainda que avaliadas e apresentadas numericamente, não foram tratadas estatisticamente. 
Tabela 3 - Identificação de problemas éticos pela amostra, de acordo com o momento de aplicação $\left(1^{\circ}, 2^{\circ}\right.$ e $\left.3^{\circ}\right)$ do IPE-APS Santo André 2010

\begin{tabular}{|c|c|c|c|c|c|c|}
\hline \multirow[b]{2}{*}{ Problema Eticos } & \multicolumn{3}{|c|}{ Não Identificam } & \multicolumn{3}{|c|}{ Identificam } \\
\hline & $1^{\circ}$ & $2^{\circ}$ & $3^{a}$ & $1^{\circ}$ & $2^{\circ}$ & $3^{a}$ \\
\hline 1. Dificuldade para estabelecer os limites da relação profissional-usuário & 0 & 0 & 0 & 12 & 12 & 12 \\
\hline 2. Pré-julgamento dos usuários dos serviços por parte das equipes & 01 & 0 & 0 & 11 & 12 & 12 \\
\hline 3. O profissional trata o usuário com falta de respeito & 0 & 0 & 0 & 12 & 12 & 12 \\
\hline 4. Prescrições inadequadas ou erradas & 0 & 0 & 0 & 12 & 12 & 12 \\
\hline 5. Prescrição de medicamentos que o usuário não poderá comprar & 0 & 0 & 0 & 12 & 12 & 12 \\
\hline 6. Prescrição de medicamentos mais caros mesmo que ele tenha eficácia igual a dos mais baratos & 0 & 0 & 0 & 12 & 12 & 12 \\
\hline 7. Usuário solicita ao médico e ao enfermeiro os procedimentos que deseja & 0 & 0 & 0 & 12 & 12 & 12 \\
\hline 8. Como convencer o usuário a dar continuidade ao tratamento & 0 & 0 & 0 & 12 & 12 & 12 \\
\hline 9. Não contar ao usuário informações referentes ao seu estado de saúde & 0 & 0 & 0 & 12 & 12 & 12 \\
\hline 10. Acesso dos profissionais de saúde à intimidade da vida da família e do casal & 0 & 0 & 0 & 12 & 12 & 12 \\
\hline 11. É difícil manter a privacidade do usuário nos atendimentos feitos em sua casa & 0 & 0 & 0 & 12 & 12 & 12 \\
\hline 12. É difícil para o ACS guardar o segredo profissional & 0 & 0 & 0 & 12 & 12 & 12 \\
\hline 13. Contar as informações da saúde de um dos membros da família para os demais & 0 & 0 & 0 & 12 & 12 & 12 \\
\hline 14. Falta de compromisso e envolvimento de alguns dos profissionais que atuam no PSF & 0 & 0 & 0 & 12 & 12 & 12 \\
\hline 15. As equipes de saúde da família não colaboram umas com as outras & 0 & 0 & 0 & 12 & 12 & 12 \\
\hline 16. Falta de respeito entre os membros da equipe & 0 & 0 & 0 & 12 & 12 & 12 \\
\hline 17. Falta de preparo dos profissionais para trabalhar no PSF & 0 & 0 & 0 & 12 & 12 & 12 \\
\hline 18. É difícil limitar o papel e as responsabilidades de cada profissional & 0 & 0 & 0 & 12 & 12 & 12 \\
\hline 19. Profissionais se omitem diante de uma prescrição inadequada ou errada & 0 & 0 & 0 & 12 & 12 & 12 \\
\hline $\begin{array}{l}\text { 20. Usuários pedem a um dos membros da equipe para guardar segredo de algo sobre sua saúde e para não contar nada aos demais } \\
\text { membros da equipe de PSF }\end{array}$ & 01 & 0 & 0 & 11 & 12 & 12 \\
\hline 21. Dificuldades para preservar privacidade por problemas na estrutura física e rotinas da USF & 0 & 0 & 0 & 12 & 12 & 12 \\
\hline 22. Falta de apoio com ações intersetoriais para discutir e resolver os problemas éticos & 0 & 0 & 0 & 12 & 12 & 12 \\
\hline 23. Falta de transparência da direção da UBS na resolução de problemas com os profissionais & 0 & 0 & 0 & 12 & 12 & 12 \\
\hline
\end{tabular}


Tabela 3 - Identificação de problemas éticos pela amostra, de acordo com o momento de aplicação $\left(1^{\circ}, 2^{\circ}\right.$ e $\left.3^{\circ}\right)$ do IPE-APS - Santo André 2010

\begin{tabular}{|c|c|c|c|c|c|c|}
\hline \multirow[b]{2}{*}{ Problema Éticos } & \multicolumn{3}{|c|}{ Não Identificam } & \multicolumn{3}{|c|}{ Identificam } \\
\hline & $1^{\circ}$ & $2^{\circ}$ & $3^{a}$ & $1^{\circ}$ & $2^{\circ}$ & $3^{\mathrm{a}}$ \\
\hline 24. Excesso de famílias adscritas para cada equipe & 0 & 0 & 0 & 12 & 12 & 12 \\
\hline 25. Restrição do acesso dos usuários à UBS pelos médicos que se recusam a atender os que não têm consulta marcada para o dia & 0 & 0 & 0 & 12 & 12 & 12 \\
\hline 26. Demérito dos encaminhamentos feitos pelos médicos do PSF & 0 & 0 & 0 & 12 & 12 & 12 \\
\hline 27. Dificuldades e falta de referência para realizar exames complementares & 01 & 0 & 0 & 12 & 12 & 12 \\
\hline 28. Dificuldades quanto ao retorno e confiabilidade dos resultados de exames laboratoriais & 01 & 0 & 0 & 12 & 12 & 12 \\
\hline 29. É difícil limitar a interferência da equipe no estilo de vida das famílias e usuários & 0 & 0 & 0 & 12 & 12 & 12 \\
\hline 30. Atitude do médico diante de valores religiosos próprios e dos usuários. & 0 & 0 & 0 & 12 & 12 & 12 \\
\hline 31. Menores de idade pedem à equipe procedimentos e exames sem a autorização ou o conhecimento de seus pais & 0 & 0 & 0 & 12 & 12 & 12 \\
\hline 32. Usuários que se recusam a seguir as indicações médicas ou a fazerem exames & 0 & 0 & 0 & 12 & 12 & 12 \\
\hline 33. A equipe discute as condições de saúde do usuário na frente dele, sem que ele participe & 0 & 0 & 0 & 12 & 12 & 12 \\
\hline 34. Não solicitar a autorização da família para relatar a história do usuário em publicação científica & 0 & 0 & 0 & 12 & 12 & 12 \\
\hline 35. Funcionários da USF questionam a prescrição médica & 0 & 0 & 0 & 12 & 12 & 12 \\
\hline 36. Quebra do sigilo médico por outros membros que não são da equipe ao publicarem relato de casos & 0 & 0 & 0 & 12 & 12 & 12 \\
\hline 37. Equipe especialista de referência para o PSF publica um relato de caso sem a autorização da equipe de PSF ou da família & 0 & 0 & 0 & 12 & 12 & 12 \\
\hline 38. Falta de estrutura na USF para a realização de visitas domiciliares & 0 & 0 & 0 & 12 & 12 & 12 \\
\hline 39. Falta de condições na USF para atendimentos de urgência & 0 & 0 & 0 & 12 & 12 & 12 \\
\hline 40. Falta de retaguarda de serviço de remoção & 0 & 0 & 0 & 12 & 12 & 12 \\
\hline
\end{tabular}

\footnotetext{
Fonte: Dados primários
} 
Tabela 4 - Distribuição da frequência da ocorrência de problemas éticos na amostra segundo o momento $\left(1^{\circ}, 2^{\circ}\right.$ e $\left.3^{\circ}\right)$ de aplicação do IPE-APS - Santo André - 2010

\begin{tabular}{|c|c|c|c|c|c|c|}
\hline \multirow[b]{2}{*}{ Problema Eticos } & \multicolumn{3}{|c|}{ Ocasionalmente/ comumente } & \multicolumn{3}{|c|}{ Nunca } \\
\hline & $1^{\circ}$ & $2^{\circ}$ & $3^{a}$ & $1^{\circ}$ & $2^{\circ}$ & $3^{a}$ \\
\hline 1. Dificuldade para estabelecer os limites da relação profissional-usuário & 12 & 12 & 12 & 0 & 0 & 0 \\
\hline 2. Pré-julgamento dos usuários dos serviços por parte das equipes & 10 & 12 & 7 & 1 & 0 & 5 \\
\hline 3. O profissional trata o usuário com falta de respeito & 10 & 10 & 9 & 2 & 2 & 7 \\
\hline 4. Prescrições inadequadas ou erradas & 10 & 9 & 11 & 2 & 3 & 1 \\
\hline 5. Prescrição de medicamentos que o usuário não poderá comprar & 9 & 9 & 10 & 3 & 3 & 2 \\
\hline 6. Prescrição de medicamentos mais caros mesmo que ele tenha eficácia igual a dos mais baratos & 9 & 8 & 8 & 3 & 4 & 4 \\
\hline 7. Usuário solicita ao médico e ao enfermeiro os procedimentos que deseja & 12 & 9 & 12 & 0 & 3 & 0 \\
\hline 8. Como convencer o usuário a dar continuidade ao tratamento & 12 & 12 & 12 & 0 & 0 & 0 \\
\hline 9. Não contar ao usuário informações referentes ao seu estado de saúde & 9 & 7 & 8 & 3 & 5 & 4 \\
\hline 10. Acesso dos profissionais de saúde à intimidade da vida da família e do casal & 11 & 11 & 11 & 1 & 1 & 1 \\
\hline 11. É difícil manter a privacidade do usuário nos atendimentos feitos em sua casa & 10 & 12 & 12 & 2 & 0 & 0 \\
\hline 12. É difícil para o ACS guardar o segredo profissional & 11 & 11 & 12 & 1 & 1 & 0 \\
\hline 13. Contar as informações da saúde de um dos membros da família para os demais & 12 & 11 & 11 & 0 & 1 & 1 \\
\hline 14. Falta de compromisso e envolvimento de alguns dos profissionais que atuam no PSF & 10 & 11 & 12 & 2 & 1 & 0 \\
\hline 15. As equipes de saúde da família não colaboram umas com as outras & 8 & 7 & 8 & 4 & 5 & 4 \\
\hline 16. Falta de respeito entre os membros da equipe & 7 & 9 & 9 & 5 & 3 & 3 \\
\hline 17. Falta de preparo dos profissionais para trabalhar no PSF & 11 & 11 & 12 & 1 & 1 & 0 \\
\hline 18. É difícil limitar o papel e as responsabilidades de cada profissional & 11 & 11 & 12 & 1 & 1 & 0 \\
\hline 19. Profissionais se omitem diante de uma prescrição inadequada ou errada & 7 & 9 & 9 & 5 & 3 & 3 \\
\hline $\begin{array}{l}\text { 20. Usuários pedem a um dos membros da equipe para guardar segredo de algo sobre sua saúde e para não contar nada aos demais } \\
\text { membros da equipe de PSF }\end{array}$ & 8 & 10 & 9 & 3 & 2 & 3 \\
\hline 21. Dificuldades para preservar privacidade por problemas na estrutura física e rotinas da USF & 9 & 11 & 10 & 3 & 1 & 2 \\
\hline 22. Falta de apoio com ações intersetoriais para discutir e resolver os problemas éticos & 6 & 11 & 10 & 5 & 0 & 1 \\
\hline 23. Falta de transparência da direção da UBS na resolução de problemas com os profissionais & 10 & 12 & 11 & 2 & 0 & 1 \\
\hline
\end{tabular}




\begin{tabular}{|c|c|c|c|c|c|c|}
\hline \multirow[b]{2}{*}{ Problema Éticos } & \multicolumn{3}{|c|}{ Ocasionalmente/ comumente } & \multicolumn{3}{|c|}{ Nunca } \\
\hline & $1^{\circ}$ & $2^{\circ}$ & $3^{a}$ & $1^{\circ}$ & $2^{\circ}$ & $3^{\mathrm{a}}$ \\
\hline 24. Excesso de famílias adscritas para cada equipe & 11 & 12 & 12 & 1 & 0 & 0 \\
\hline 25. Restrição do acesso dos usuários à UBS pelos médicos que se recusam a atender os que não têm consulta marcada para o dia & 8 & 9 & 7 & 4 & 3 & 5 \\
\hline 26. Demérito dos encaminhamentos feitos pelos médicos do PSF & 10 & 9 & 11 & 2 & 3 & 1 \\
\hline 27. Dificuldades e falta de referência para realizar exames complementares & 11 & 11 & 12 & 0 & 1 & 0 \\
\hline 28. Dificuldades quanto ao retorno e confiabilidade dos resultados de exames laboratoriais & 10 & 11 & 12 & 1 & 1 & 0 \\
\hline 29. É difícil limitar a interferência da equipe no estilo de vida das famílias e usuários & 10 & 11 & 10 & 1 & 1 & 2 \\
\hline 30. Atitude do médico diante de valores religiosos próprios e dos usuários. & 5 & 7 & 6 & 7 & 5 & 6 \\
\hline 31. Menores de idade pedem à equipe procedimentos e exames sem a autorização ou o conhecimento de seus pais & 10 & 9 & 8 & 2 & 3 & 4 \\
\hline 32. Usuários que se recusam a seguir as indicações médicas ou a fazerem exames & 11 & 12 & 12 & 1 & 0 & 0 \\
\hline 33. A equipe discute as condições de saúde do usuário na frente dele, sem que ele participe & 3 & 5 & 7 & 9 & 7 & 5 \\
\hline 34. Não solicitar a autorização da família para relatar a história do usuário em publicação científica & 0 & 2 & 5 & 12 & 10 & 7 \\
\hline 35. Funcionários da USF questionam a prescrição médica & 5 & 9 & 9 & 8 & 3 & 3 \\
\hline 36. Quebra do sigilo médico por outros membros que não são da equipe ao publicarem relato de casos & 0 & 1 & 4 & 12 & 11 & 8 \\
\hline 37. Equipe especialista de referência para o PSF publica um relato de caso sem a autorização da equipe de PSF ou da família & 0 & 1 & 4 & 12 & 11 & 8 \\
\hline 38. Falta de estrutura na USF para a realização de visitas domiciliares & 11 & 11 & 12 & 1 & 1 & 0 \\
\hline 39. Falta de condições na USF para atendimentos de urgência & 12 & 12 & 12 & 0 & 0 & 0 \\
\hline 40. Falta de retaguarda de serviço de remoção & 11 & 11 & 12 & 1 & 1 & 0 \\
\hline
\end{tabular}

\section{Fonte: Dados primários}




\subsection{A OPINIÃO DOS PARTICIPANTES QUANTO A UTILIDADE E ADEQUAÇÃO DA PROPOSTA PARA O SEU TRABALHO NA AB}

Os resultados desse ponto são apresentados por súmulas que sintetizam os dados obtidos no formulário de questões abertas, depois da análise de conteúdo a que foram submetidas as suas respostas. Dessa forma, a seguir, serão apresentadas, de maneira sintética, algumas características que, em certa medida, descrevem a visão dos participantes.

\section{O que você aprendeu durante as sessões de deliberação do curso?}

Os conteúdos que os participantes do curso de capacitação trouxeram a respeito do que teriam aprendido na capacitação em deliberação, assim como a construção que foi elaborada após o curso, são expressos através da Figura 1 , onde se observa que na aprendizagem houve modificações antes e depois da capacitação em bioética.

Isso aponta que a problematização atende a características do método socrático de ensino da bioética.

Como vimos, distinguem-se dois enfoques para o ensino da bioética: pedagógico e socrático. O primeiro é o mais comum. Centra-se na transmissão de conhecimentos, enfocando o processo de ensino a partir da elaboração, implementação e avaliação de um "programa". Nele tem-se um processo de ensino a partir do ponto de vista da concepção, implementação e avaliação dos professores (Gracia 1998).

No enfoque socrático, sem descuidar do rigor dos conteúdos, prioriza-se a transformação do ser, pois isso era o que Sócrates buscava nos diálogos com seus discípulos. Como vimos, o procedimento docente deste enfoque é a maiêutica, do grego maia (partejar); "fazer nascer", "trazer à luz" o melhor que cada um tem dentro de si mesmo. O enfoque socrático, então, propõe a facilitar a transformação interior das atitudes, além de levar ao conhecimento.

Os resultados apresentados fornecem informações relacionadas a três aspectos que foram elaborados a partir dos conteúdos trabalhados durante a capacitação. 
O primeiro, a aplicação na prática da bioética, representa a ação da bioética em sua vida, com vistas a que se propicie a transformação da prática profissional a partir da incorporação de valores que resultem em mudanças atitudinais. Isto é, a interpretação de dados e o estabelecimento de conexões de sentido que permitam identificar e abordar, de maneira mais abrangente e próxima da realidade, os conflitos éticos que surgem no trabalho diário.

Como relatam alguns depoimentos, registrados nos questionários:

"Eu aprendi a avaliar os problemas e situações cotidianas desde vários pontos de vista".

"Analisar melhor os casos (clínicos)".

"A aprofundar um caso, sem pré-julgamento da situação".

$O$ refinamento de competências e habilidades na percepção de problemas éticos abrange a incorporação na prática clínica de saberes e habilidades da bioética e da deliberação moral, diferenciando a especificidade da bioética, distinguindo-a do direito e da deontologia profissional na percepção dos problemas éticos e dos conflitos de valores que subjazem a prática profissional cotidiana na atenção básica:

"Podemos tomar decisões, decisões adequadas sem ferir princípios éticos".

"Organizar o pensamento a fim de traçar o curso de melhor resultado possível".

"Eu aprendi a avaliar os problemas e situações cotidianas desde vários pontos de vista e escolher a melhor solução".

"Esgotar todos os esclarecimentos do fato, ter mais paciência ao invés de tentar resolver o mais rápido possível, achar a possibilidade mais cabivel para o momento". 
No aprimoramento de práticas para o manejo de problemas éticos, a abordagem permitiu integrar fatos, valores e deveres no processo de deliberação, para ser capaz de argumentar suas decisões. A aplicação dos passos do método de deliberação moral na análise compreensiva dos problemas éticos, ou seja, percorrer o itinerário da deliberação, permitiu apropriar-se de uma via para chegar a decisões consistentes e argumentadas do ponto de vista moral, a partir da operação de uma racionalidade problemática na identificação de cursos de ação intermédiárias e do ótimo na deliberação moral:

"Que existem diversos caminhos a seguir diante de um problema ético e deliberar sobre o tema nos possibilita chegar a melhor resolutividade possível e nos da respaldo na decisão".

"Que é importante discutirmos ou deliberarmos sobre o problema ético em que nos encontramos ou outros, pois nem sempre a nossa visão é suficiente para chegarmos à uma conclusão com ou sem solução".

“Aprendi que para deliberar é necessário avaliar de forma sistematizada e critica, atentando para as peculiaridades, ponderando as situações, valores, conflitos. Melhoria na qualidade da pratica profissional, analise e autoeducação continuamente para compreensão mais clara, evitando juízos sem reflexão dos problemas. Sensibilização, responsabilidade moral, aprimoramento de questões relacionadas à bioética - comunicação, respeito, escuta”. 
Figura 3 Representação do que foi aprendido no curso de deliberação moral

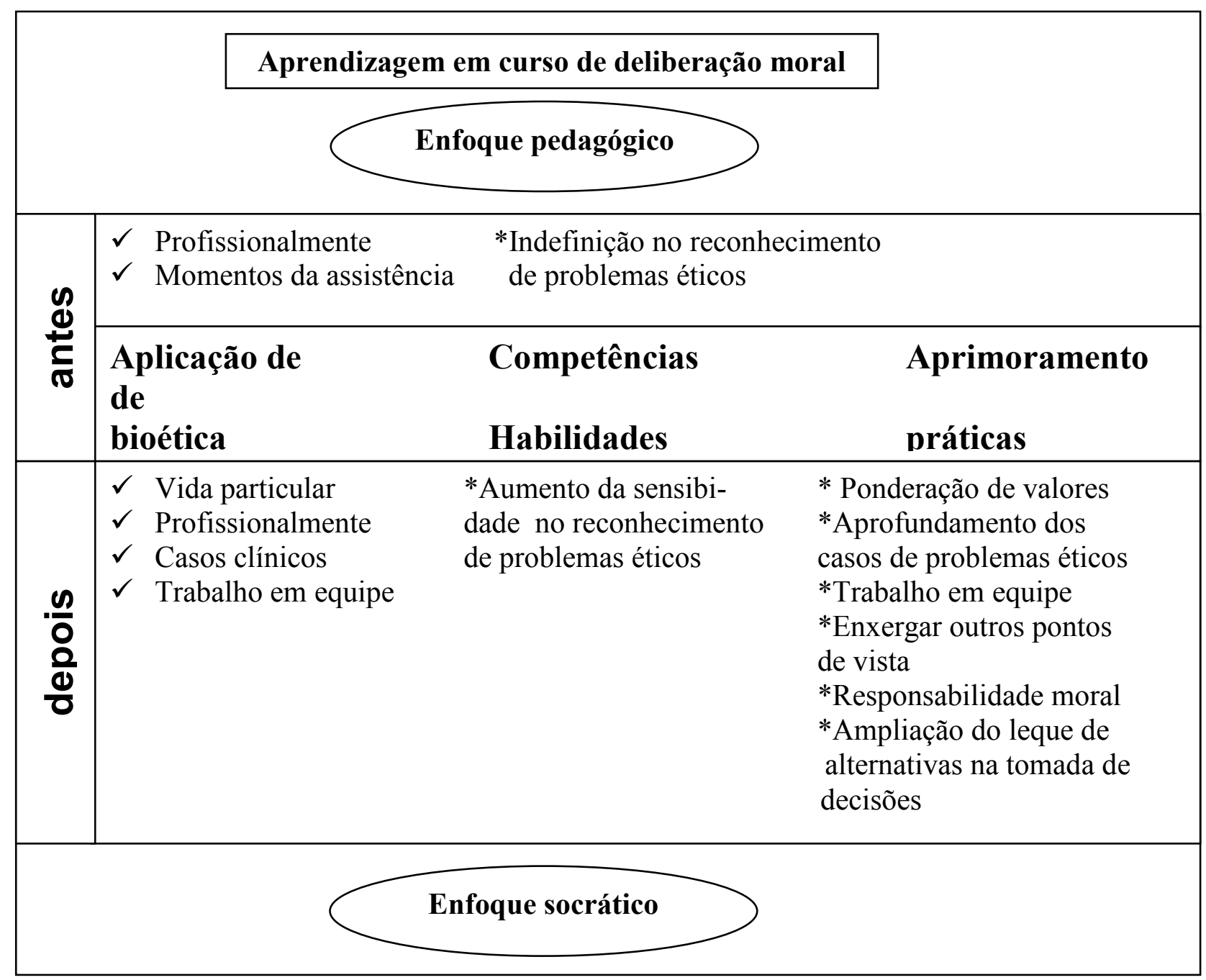

\section{Do que você sentiu falta durante as sessões de deliberação do curso?}

Neste quesito, procurou-se investigar em que medida a estrutura do curso e seus conteúdos teórico-práticos abarcavam as expectativas dos participantes. Também queria se avaliar se a carga horária estava adequada para as atividades propostas.

As avaliações indicaram a necessidade de ampliar a carga horária do segundo momento de concentração para que todos possam apresentar seus casos:

"Senti falta de mais sessões de deliberação". 
"Tempo para discutir outros casos, mas os que foram apresentados foram produtivos".

"Pouco tempo para apresentação do caso e ser muito rico de detalhes".

Figura 4 Capacitação em bioética clínica e deliberação moral

\begin{tabular}{|c|c|c|}
\hline \multicolumn{3}{|c|}{ Capacitação em deliberação moral } \\
\hline Bloco teórico & $\begin{array}{l}\text { Momento } \\
\text { dispersão }\end{array}$ & $\begin{array}{l}\text { Bloco teórico- } \\
\text { pratico }\end{array}$ \\
\hline $\begin{array}{l}\text { Conteúdo } \\
\text { programático } \\
\text { composto de três } \\
\text { unidades: gênese, } \\
\text { trajetória, concepções } \\
\text { e abrangência da } \\
\text { bioética }\end{array}$ & $\begin{array}{l}\text { Levantamento de um } \\
\text { problema ético } \\
\text { vivenciado em sua } \\
\text { prática e prepará-lo } \\
\text { para sessões de } \\
\text { deliberação }\end{array}$ & $\begin{array}{l}\text { Apresentação dos } \\
\text { casos para sessões de } \\
\text { deliberação }\end{array}$ \\
\hline
\end{tabular}

\section{Influência do curso sobre bioética e deliberação moral na prática nos trabalho diário}

Como se pode verificar na figura 3 , a abordagem da influência da capacitação na prática profissional foi explicitada de duas formas: atribuição e atuação profissionais.

$\mathrm{Na}$ língua portuguesa, segundo o Ferreira, (2004), atribuição compreende a ação de atribuir a alguém: um papel a um ator, poderes, competência. Pensamos que o uso dessa palavra descritora pelos participantes identifica que ganharam algo, tanto em conhecimento como em poder para lidar com as situações problemáticas.

A capacitação em bioética e deliberação conferem potencialidade ao profissional de saúde, através da apreensão de novos conteúdos e novas formas de lidarem com os aspectos éticos da clínica, uma vez que ao iniciarem a capacitação nenhum deles conhecia o método de deliberação, tendo 
discutido poucos elementos sobre a temática da bioética, especialmente na atenção básica.

\section{Um dos participantes elaborou uma discurso emblemático que} define um conceito, uma vez que houve agregação de novos conteúdos:

"Compreensão dos problemas éticos, tomada de decisão consistente argumentando sempre do ponto de vista moral, melhora da percepção dos problemas na prática diária, fazer a integração dos fatos, valores e deveres para argumentar as decisões, saber separar e manejar valores em conflito e problemas éticos, procurar sensibilizar os profissionais ao redor com atitudes profissionais, respeitosamente, dialogando, prudentemente de maneira clara e compreender que nem sempre vai ser possível resolver o problema”.

Figura 5 Influência do curso sobre bioética e deliberação moral na prática nos trabalho diário

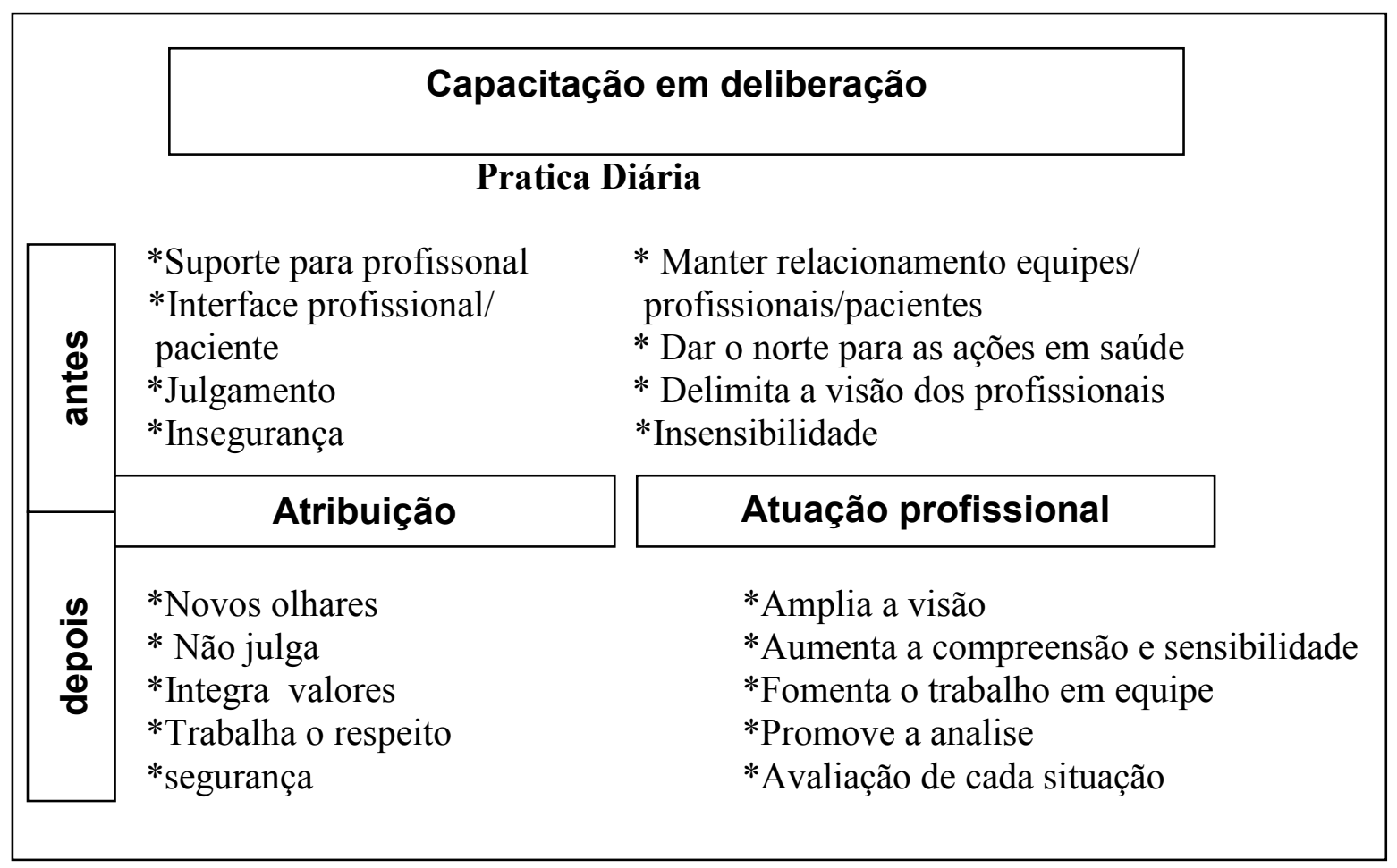




\section{CONSIDERAÇÕES FINAIS}

Esta pesquisa, que se caracterizou como um estudo qualitativo do tipo antes e depois, teve como objetivo analisar o impacto de uma ação educativa em bioética clínica e deliberação moral aplicadas à atenção básica, com a finalidade de identificar se a percepção de problemas éticos se modificaria e se esta ação traria contribuições com aportes para lidar com as questões éticas na prática.

Os resultados mostram que os profissionais que participaram da ação educativa modificaram sua percepção quanto às situações eticamente problemáticas e seus depoimentos apontam que houve um aporte para lidarem de maneira mais responsável e compreensiva com tais situações em sua prática clínica na atenção básica.

A problematização mostrou-se efetiva como estratégia educativa para o ensino-aprendizagem na formação contínua dos profissionais em bioética deliberativa.

O enfoque problematizador possibilitou a construção da aprendizagem das habilidades que permitiu a identificação dos conflitos éticos que se encontravam subentendidos no trabalho dos profissionais de saúde, tornandoos capazes de analisá-los criticamente, para uma tomada de decisões eticamente consistentes e publicamente sustentáveis.

Os profissionais de saúde demonstraram entusiasmo durante a realização da ação educativa, apercebendo-se da necessidade de darem mais atenção para a deliberação moral como parte de seus processos de trabalho. Compreenderem que, através do processo da deliberação, podem incorporar elementos da realidade com potencial para efetivar o cuidado integral ao paciente. Assim, os profissionais saíram sensibilizados para prestar mais atenção às questões éticas de seu cotidiano.

Houve o desenvolvimento de habilidades para a reflexão sobre seu trabalho; tornaram-se conscientes da complexidade dos casos aparentemente simples e da diversidade de perspectivas a respeito de um caso, havendo múltiplos caminhos prudentes para sua solução. 
Eles também aprenderam a reconhecer a inerente dimensão moral do cuidado e do processo de cuidar, mesmo em situações que, em primeira mão, parecia envolver questões de ordem prática ou de comunicação, somente.

A capacitação em bioética deliberativa desenvolvida com os enfermeiros e médicos de saúde da família de Santo André (SP, Brasil) mostrou-se bem sucedida, tendo em vista as avaliações positivas dos participantes que a consideraram um curso esclarecedor, bem elaborado e que propiciou subsídios para melhorar suas condutas e decisões no trabalho nas unidades básicas de saúde.

Uma crítica que os participantes registraram foi a necessidade de ampliar o tempo para a aplicação prática do procedimento de deliberação e de se prever reuniões de acompanhamento prospectivo.

A ação educativa mostrou impacto positivo na percepção dos problemas éticos e nos aportes para lidar com tais situações no trabalho de enfermeiros e médicos da atenção básica.

Tendo em vista este impacto positivo, consideramos que a capacitação em bioética clínica e deliberação para atenção básica, calcada no enfoque problematizador pode ser uma via potente para a ativar o giro ético requerido para a efetivação do SUS. 


\section{REFERÊNCIAS BIBLIOGRÁFICAS}

Aguiar KF, Rocha ML. Pesquisa-intervenção e a produção de novas análises. Psicologia. Ciência e. Profissão. vol. 23, no.4, p.64-73, 2003.

Amado JDA. Avaliação de ocorrência de problemas éticos em cuidados de saúde primários. Portugal; 2010. [Dissertação de Mestrado - Universidade Católica Portuguesa].

Ayres JRCM. Uma concepção hermenêutica de saúde. Physis; 2007.17(1). Disponivel em: http://www.scielo.br/scielo.

Bardin L. Análise de conteúdo. Lisboa: Edições 70,1977.

Mattos R, Pinheiro R; Ceccim, R. Ensinar saúde: a integralidade e o SUS nos cursos de graduação na área da saúde. Rio de Janeiro: Cepesc, 2006. p. 131151.

Batista et al. O Enfoque problematizador na formação de profissionais da saúde. Revista Saúde Pública; 2005; vol 39; n²; p. 321- 237.

Bogdan, RC; Biklen, S.K. Investigação qualitativa em educação - uma introdução à teorias e aos métodos.Porto:Porto Editora,1994.P.150-175.

Bordenave JED; Pereira A. Estratégias de ensino e aprendizagem. $4^{\text {a }}$ edição. Petropolis: Vozes; 1982.

Brasil MS. Secretaria de Atenção a Saúde. Departamento de Atenção Básica Departamento de Atenção Básica. - 4. ed. - Brasília : Ministério da Saúde; 2007.

Batista N, Batista SH, Goldenberg P, Seiffert O, Sonzogno MC. O enfoque problematizador na formação de profissionais da saúde. Rev. Saúde Pública [periódico na Internet]. 2005 Abr [citado 2010 Nov 12] ; 39(2): 231-237. Disponível em: http://www.scielo.br/scielo.

Catão F. A pedagogia ética. Petrópolis: Vozes, 1997

Cortina A. Ética de la razón cordial: educar en la ciudadanía en el siglo XXI. Oviedo: Nobel; 2007. 270 p.

Couceiro A. Bioética para clínicos. Madrid: Editorial Triacastela; 1999.

Dordoni P. Bioética y pluralismo: el método socrático e la tradición de Leonard Nelson y Gustav Heckman en medicina. Madrid; 2007. [tese de doutorado apresentada á Universidade Complutense de Madrid]. 
Ferreira, $\mathrm{ABH}$. Aurélio dicionário da língua portuguesa. $6^{\mathrm{a}}$ edição. Curitiba, 2004

Fundação Seade. Perfil Municipal Santo André.: [texto internet]. [citado 2009 nov. 12]. Disponível em: <http://www.seade.gov.br>

Germano RM. A ética e o ensino de ética na enfermagem do Brasil. São Paulo: Cortez; 1993.

Gottschalk CMC. Maiêutica socrática ou terapia wittgensteiniana?. In: $30^{\mathrm{a}}$ Reunião Anual da ANPEd; 2007, Caxambu; ANPEd: 30 anos de pesquisa e compromisso social, 2007. p. 1-14.

Gracia D. La enseñanza de la bioética en España: un enfoque socrático. In: Saraiba J, ed. Asociación de Bioética Fundamental y Clínica: La Bioética lugar de encuentro. Actas del II Congreso Nacional. Madrid: ABFyC; 1998. p. 73-84.

Gracia D. Bioética clínica. Santa Fé de Bogotá: El Buho; 1998a.

Gracia D. La deliberación moral. El papel de las metodologías en ética clínica. In: Sarabia J, De Los Reyes M. (editor) Comités de ética asistencial. Madrid: Asociación de Bióetica Fundamental y Clínica, 2000, 21-41.

Gracia D. La deliberación moral: el método de la ética clínica. Medicina Clinica; 2001. 117: 18-23 Moral Deliberation: the role of methodologies in clinical ethics. Medicine, Health Care and Philosophy; 2001. 4: 223-32.

Gracia D. La deliberación moral: el método de la ética clínica. In: Gracia D, Júdez J. ed. Ética ne la práctica clínica. Madrid: Fundación de Ciencias de la Salud/Triacastela: 2004. p. 21-32.

Gracia D. Como arqueros al blanco. Estudios de bioetica. Madrid: Triacastela; 2004a.

Gracia D Procedimientos de decisión en ética clínica. Madrid: Tricastela; 2007. p. 157.

Gracia D. El derecho a prohibir y El derecho a consumir [conferencia de clausura]. In: Congreso Hablemos de Drogas: famílias y jóvenes, juntos por La prevención; 2009 Jun 3-5; Barcelona, ES [evento en Web]. Barcelona: Fundación de Ayuda contra la Drogadicción; 2009. [citado 2010 Jan 10]. Disponible http://www.congresohablemosdedrogas.es/_index.php?language=es [1].

Gutierrez BJ. Et al. Efectividad de un curso de formación en bioética y de la implantación de una checklist en la detección de problemas éticos en un equipo de soporte de atención domiciliaria. Atención Primaria; 2004. Vol.34 Núm. 01. 
Instituto Brasileiro de Geografia e Estatística (IBGE). Censo demográfico [texto internet]. Rio de Janeiro [citado 2009 nov. 12]. Disponível em http://www.ibge.gov.br

Kuiava, AE. Sangalli, IJ. Formação Ética e Valores Morais no Processo de Ensino e Aprendizagem. In: Carbonara V. et al. (org). Filosofia, Formação Docente e Cidadania. Coleção Filosofia e Ensino, (12). ljuí: Editora Unijuí, 2008.

La Taille Y. Moral e ética: dimensões intelectuais e afetivas. Porto Alegre: Artmed; 2006. p 28-36.

La Taille Y. Crise de Valores ou Valores em Crise. Porto Alegre: Artmed; 2009.

Pose C, Gracia D. Introducción a la bioética: origen, fundamentación y metodo [material didáctico del curso]. Madrid: Universidad Complutense; 2006.

Pose C. Lo bueno y lo mejor: introducción a la bioética médica. Madrid: Triacastela; 2009. 133p.

Rimoni J. Análise de uma intervenção pedagógica em centros de saúde e seu impacto na assistência e na gestão. In. Merhy EE, et al. Trabalho em saúde: olhando e experienciando o SUS no cotidiano. São Paulo. Hucitec, 2003 p 199 $-296$.

Santo André. Prefeitura do Município. Secretaria de Desenvolvimento Econômico e Trabalho. Anuário de Santo André 2009; Santo André, 2009.

Scheler M. Ética. $3^{\mathrm{a}}$ ed. Madrid: Caparroz; 2001. 758 p.

Silva LT, Zoboli, ELCP, Borges, ALV Bioética e atenção básica: um estudo exploratório dos problemas éticos vividos por enfermeiros e médicos no psf, Cogitare Enfermagem; 2006. mai/ago; 11(2):133-42.

Silva LT. Construção e validação de um instrumento para avaliação de ocorrência de problema ético na Atenção Básica [tese de mestrado]. São Paulo: Escola de Enfermagem, Universidade de São Paulo; 2008.

Volkmer SAJ. O perceber do valor na ética material de Max Scheler [dissertação]. Porto Alegre: Faculdade de Filosofia e Ciências Humanas, Pontifícia Universidade Católica do Rio Grande do Sul; 2006.

Zoboli ELCP. Bioética e atenção básica: um estudo de ética descritiva com enfermeiros e médicos do Programa Saúde da Família. São Paulo; 2003. [Tese de Doutorado - Faculdade de Saúde Pública da Universidade].

Zoboli ELCP. Os enfoques da bioética e a intervenção em enfermagem em saúde coletiva. Cadernos. Faculdades Integradas São Camilo, v. 12, p. 51-56, 2006. 
Zoboli ELCP. Bioética e atenção básica: para uma clínica ampliada, uma Bioética clínica amplificada. O Mundo da Saúde São Paulo; 2009. 33(2):195204.

Zoboli ELCP Deliberação: leque de possibilidades para compreender os conflitos de valores na prática clínica da atenção básica - São Paulo, 2010.. [Tese Livre-docência] Escola de Enfermagem da Universidade de São Paulo, $350 \mathrm{p}$.

Zoboli ELCP. Relación clínica y problemas éticos en atención primaria, São Paulo, Brasil. Atención Primaria (Barcelona. Ed. impresa), v. 42, p. 406-414, 2010. 
ANEXOS 


\section{Anexo A}

IPE-APS - Inventário de problemas éticos na atenção básica

\section{UNIVERSIDADE DE SÃO PAULO- ESCOLA DE ENFERMAGEM- \\ ATUALIZAÇÃO EM BIOÉTICA PARA PROFISSIONAIS DE SAÚDE NA ATENÇÃO BÁSICA DO SUS}

Responsáveis: Profa. Dra. Elma Lourdes Campos Pavone Zoboli e Fátima A C Soares

O IPE-APS é um questionário auto-aplicado para investigar problemas éticos vividos por enfermeiros e médicos que trabalham em saúde da Família. Na “Atualização em Bioética", será aplicado em três momentos diferentes para avaliar o curso. Ele é um instrumento validado para a língua portuguesa, que vem sendo construído com base nos relatos de profissionais de saúde da família em diferentes projetos pelo Brasil e Portugal.

O IPE-APS é anônimo, bastando que identifique alguns dados para sócio-demográficos.

1.) Profissão: En.( ) Enfermeiro Me.( ) Médico

2.) Sexo: $\mathrm{F}(\mathrm{M}) \quad \mathrm{M}(\mathrm{)}$

3.) Idade: __ anos.

4.) Tempo de formado: __ anos __ meses.

5.) Tempo de trabalho no PSF: __ anos _ _ meses.

Instrução para o preenchimento: que assinale com um X a alternativa que melhor expressa a sua opinião. Se você não considera o exemplo dado um problema ético, marque um X na $1^{\mathrm{a}}$ coluna. Se você considera o exemplo dado um problema ético, marque um X na freqüência com que se já se deparou com este problema em seu trabalho cotidiano na unidade de saúde. Não deixar nenhuma alternativa em branco.

\begin{tabular}{|c|c|c|c|c|}
\hline \multirow{2}{*}{ Exemplo de problema ético já identificado } & \multirow{2}{*}{$\begin{array}{l}\text { Não considero o } \\
\text { exemplo um } \\
\text { problema ético }\end{array}$} & \multicolumn{3}{|c|}{$\begin{array}{c}\text { Considero o exemplo um problema ético e o encontro } \\
\text { no meu trabalho }\end{array}$} \\
\hline & & Nunca & Ocasionalmente & Comumente \\
\hline \multicolumn{5}{|l|}{ 1. Dificuldade para estabelecer os limites da relação profissional-usuário } \\
\hline \multicolumn{5}{|l|}{ 2. Pré-julgamento dos usuários dos serviços por parte das equipes } \\
\hline \multicolumn{5}{|l|}{ 3. O profissional trata o usuário com falta de respeito } \\
\hline \multicolumn{5}{|l|}{ 4. Prescrições inadequadas ou erradas } \\
\hline \multicolumn{5}{|l|}{ 5. Prescrição de medicamentos que o usuário não poderá comprar } \\
\hline \multirow{2}{*}{\multicolumn{5}{|c|}{$\begin{array}{l}\text { 6. Prescrição de medicamentos mais caros mesmo que ele tenha eficácia igual a dos mais baratos } \\
\text { 7. Usuário solicita ao médico e ao enfermeiro os procedimentos que deseja }\end{array}$}} \\
\hline & & & & \\
\hline \multicolumn{5}{|l|}{ 8. Como convencer o usuário a dar continuidade ao tratamento } \\
\hline \multicolumn{5}{|l|}{ 9. Não contar ao usuário informações referentes ao seu estado de saúde } \\
\hline 10. Acesso dos profissionais de saúde à intimidade da vida da família e do casal & & & & \\
\hline
\end{tabular}


Exemplo de problema ético já identificado

11. É difícil manter a privacidade do usuário nos atendimentos feitos em sua casa

12. É difícil para o ACS guardar o segredo profissional

13. Contar as informações da saúde de um dos membros da família para os demais

14. Falta de compromisso e envolvimento de alguns dos profissionais que atuam no PSF

15. As equipes de saúde da família não colaboram umas com as outras

16. Falta de respeito entre os membros da equipe

17. Falta de preparo dos profissionais para trabalhar no PSF

18. É difícil limitar o papel e as responsabilidades de cada profissional

19. Profissionais se omitem diante de uma prescrição inadequada ou errada

20. Usuários pedem a um dos membros da equipe para guardar segredo de algo sobre sua saúde e para não contar nada aos

demais membros da equipe de PSF

21. Dificuldades para preservar privacidade por problemas na estrutura física e rotinas da USF

22. Falta de apoio com ações intersetoriais para discutir e resolver os problemas éticos

23. Falta de transparência da direção da UBS na resolução de problemas com os profissionais

24. Excesso de famílias adscritas para cada equipe

25. Restrição do acesso dos usuários à UBS pelos médicos que se recusam a atender os que não têm consulta marcada para o dia

26. Demérito dos encaminhamentos feitos pelos médicos do PSF

27. Dificuldades e falta de referência para realizar exames complementares

28. Dificuldades quanto ao retorno e confiabilidade dos resultados de exames laboratoriais

29. É difícil limitar a interferência da equipe no estilo de vida das famílias e usuários

30. Atitude do médico diante de valores religiosos próprios e dos usuários.

31. Menores de idade pedem à equipe procedimentos e exames sem a autorização ou o conhecimento de seus pais

32. Usuários que se recusam a seguir as indicações médicas ou a fazerem exames

33. A equipe discute as condições de saúde do usuário na frente dele, sem que ele participe

34. Não solicitar a autorização da família para relatar a história do usuário em publicação científica

35. Funcionários da USF questionam a prescrição médica

36. Quebra do sigilo médico por outros membros que não são da equipe ao publicarem relato de casos

37. Equipe especialista de referência para o PSF publica um relato de caso sem a autorização da equipe de PSF ou da família

38. Falta de estrutura na USF para a realização de visitas domiciliares

39. Falta de condições na USF para atendimentos de urgência

40. Falta de retaguarda de serviço de remoção

Considero o exemplo um problema ético e o encontro

no meu trabalho

exemplo um

problema ético

Nunca

\begin{tabular}{|c|c|c|}
\hline Nunca & Ocasionalmente & Comumente \\
\hline & & \\
\hline & & \\
\hline & & \\
\hline & & \\
\hline & & \\
\hline & & \\
\hline & & \\
\hline & & \\
\hline & & \\
\hline & & \\
\hline & & \\
\hline & & \\
\hline & & \\
\hline & & 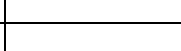 \\
\hline & & \\
\hline & & \\
\hline & & \\
\hline & & \\
\hline & & \\
\hline & & \\
\hline & & \\
\hline & & \\
\hline & & \\
\hline & & \\
\hline & & \\
\hline & & \\
\hline
\end{tabular}


Anexo B

\author{
UNIVERSIDADE DE SÃO PAULO \\ ESCOLA DE ENFERAMGEM DA USP
}

\begin{abstract}
ATUALIZAÇÃO EM BIÉTICA PARA PROFISSOINAIS DE SAÚDE NA ATENÇAO BÁSICA DO SUS
\end{abstract}

PREFEITURA MUNICIPAL DE SANTO ANDRÉ

Responsável: Profa. Dra. Elma Lourdes Campos Pavone Zoboli - EEUSP Corresponsável: Fátima Aparecida Cotrim Soares

SANTO ANDRÉ 


\section{Seqüência de atividades 1}

Objetivos: (a) Discutir, a partir das peculiaridades dos problemas éticos que os participantes vivem em sua prática profissional na atenção básica, as concepções de problema e dilema éticos (b) Designar a experiência moral, distinguindo os âmbitos dos fatos, valores e deveres

Conceito chave: experiência moral; problema ético Conhecimentos:

A experiência moral: os fatos, os valores e os deveres

Problema ético e a racionalidade problemática

Dilema ético e racionalidade dilemática e dilema ético

O problema ético como conflito de valores

\begin{tabular}{|c|c|}
\hline PARTICIPANTE & MONITOR \\
\hline $\begin{array}{l}\text { 1. Apresentação dos participantes em } \\
\text { trios }-1 \mathrm{~h}\end{array}$ & $\begin{array}{l}\text { 1. orientar para que formem trios com } \\
\text { pessoas desconhecidas } \\
\text { compartilhem, nome, profissão, local } \\
\text { de trabalho, expectativas, motivações } \\
\text { para o curso e como vêem a ética no } \\
\text { seu cotidiano. Cada um apresentará a } \\
\text { um outro companheiro do trio. } \\
\text { Observar a dinâmica dos trios para as } \\
\text { habilidades de comunicação, escuta } \\
\text { ativa, compreensiva e respeito pelas } \\
\text { singularidades, interesse pelo outro. }\end{array}$ \\
\hline
\end{tabular}

Material preparado com finalidades didáticas. Exclusivo para uso no Curso de Atualização para Profissionais de Saúde na Atenção Básica - PMSA - Não autorizada reproduçāo ou uso do material para outras finalidades 


\begin{tabular}{|c|c|}
\hline $\begin{array}{l}\text { 2. Individualmente, preencher o } \\
\text { Instrumento para Identificação de } \\
\text { Problemas Éticos na Atençăo Básica } \\
-30^{\prime}\end{array}$ & $\begin{array}{l}\text { 2. Instruir quanto à importância de } \\
\text { que este momento seja individual, } \\
\text { pois logo terão oportunidade de } \\
\text { compartilhar em grupo. Orientar que } \\
\text { não há respostas certas ou erradas. } \\
\text { Devem registrar sua visão e sua } \\
\text { vivência. O instrumento será um pré- } \\
\text { teste do curso e não do aluno, pois o } \\
\text { questionário é anônimo. }\end{array}$ \\
\hline $\begin{array}{l}\text { 3. Compartilhar, em grupos, o que } \\
\text { assinalaram ou não como problema } \\
\text { ético e porquê. Observar em que } \\
\text { problemas coincidiram, em quais } \\
\text { discordaram, como essas diferenças } \\
\text { ou semelhanças aconteceram, } \\
\text { considerando o sexo, as profissões, } \\
\text { tempo de trabalho. 1h }\end{array}$ & $\begin{array}{l}\text { 3. Dividir em } 3 \text { grupos de cinco } \\
\text { participantes e orientar cada um para } \\
\text { que iniciem a discussão por um } \\
\text { conjunto diferente de problemas, } \\
\text { considerando os três âmbitos do } \\
\text { instrumento (relaçōes com os } \\
\text { usuários e familias, relações com } \\
\text { equipe, relações com o sistema de } \\
\text { saúde). Reforçar que não há um certo } \\
\text { ou errado e que não tem que chegar a } \\
\text { nenhum consenso ou discutir os } \\
\text { casos. Somente identificar o perfil e } \\
\text { distribuição dos problemas éticos } \\
\text { assinalados ou não, observando } \\
\text { como ocorreram as concordâncias, } \\
\text { discordâncias, e o que influiu nisso. } \\
\text { Observar as habilidades de } \\
\text { comunicação e como lidam com as } \\
\text { diferentes visöes de problemas éticos }\end{array}$ \\
\hline
\end{tabular}

Material preparado com finalidades didáticas. Exclusivo para uso no Curso de Atualização para Profissjonais de Saúde na Atenção Básica - PMSA - Nāo autorizada reproduçăo ou uso do material para outras finalidades 


\begin{tabular}{|l|l|}
\hline 4. Plenária dos grupos $-45^{\prime}$ & $\begin{array}{l}\text { 4. Coordenar a plenária, com especial } \\
\text { atenção ao tempo de exposição dos } \\
\text { grupos e a dinâmica das pessoas } \\
\text { durante a atividade. Na síntese da } \\
\text { plenária chamar a atenção para os } \\
\text { fatores que podem influir na } \\
\text { consciência moral, como idade, sexo, } \\
\text { e no perfil de problemas éticos, como } \\
\text { profissão, tipo de serviço de saúde, } \\
\text { etc. }\end{array}$ \\
\hline $\begin{array}{l}\text { 5. Aula síntese: A experiência moral: } \\
\text { os fatos, valores, deveres e os } \\
\text { conflitos - 45' }\end{array}$ & $\begin{array}{l}4 . \text { Estimular a participação na aula } \\
\text { síntese }\end{array}$ \\
\hline $\begin{array}{l}\text { 6. Recolher 'os instrumentos } \\
\text { preenchidos }\end{array}$ & $\begin{array}{l}6 . \text { Orientar para que depositem os } \\
\text { instrumentos preenchidos no local } \\
\text { indicado. }\end{array}$ \\
\hline
\end{tabular}




\section{Seqüência de atividades 2}

Objetivos: (a) Distinguir as linguagens da ética, moral e direito (b) explicar a gênese, trajetória, concepções e abrangência temática da bioética, diferenciandoa ética profissional e direito (c) Apresentar a deliberação como um instrumental da bioética para o manejo e a solução de problemas éticos

Conceito chave: Bioética

\section{Conhecimentos:}

Conceituação, gênese, trajetória e abrangência temática da bioética

As diferentes linguagens e âmbitos da ética, direito e bioética

Fundamentaçăo da bioética: experiências moral e ética, prudência e responsabilidade

O processo de deliberação e os procedimentos para a análise do caso

\begin{tabular}{|c|c|}
\hline PARTICIPANTE & MONITOR \\
\hline $\begin{array}{l}\text { 1. individualmente, por meio da } \\
\text { associação de palavras, traçar as } \\
\text { concepções de ética, moral, direito e } \\
\text { bioética - } 30^{\prime}\end{array}$ & $\begin{array}{l}\text { 1. Explicar que não há certo e errado, } \\
\text { pois o objetivo é colher as } \\
\text { associações espontâneas relativas às } \\
\text { palavras. Distribuir folhas para o } \\
\text { registro de cada uma das } \\
\text { associações. Pedir para que } \\
\text { associem, livre e rapidamente, a partir } \\
\text { da audição das palavras ética, moral, } \\
\text { direito e bioética outras palavras que } \\
\text { lhe venham à mente (adjetivos, } \\
\text { substantivos, verbos, expressões, } \\
\text { nomes próprios, de filmes, de livros, } \\
\text { etc). Cada associaçăo deverá ser } \\
\text { lançada numa folha que será } \\
\text { recolhida ao término do tempo. Os } \\
\text { participantes não deverão conhecer o }\end{array}$ \\
\hline
\end{tabular}

Material preparado com finalidades didáticas. Exclusivo para uso no Curso de Atualização para Profissionais de Saúde na Atenção Básica - PMSA - Não autorizada reproduçâa ou uso do material para cutras finalidades 


\begin{tabular}{|c|c|}
\hline & $\begin{array}{l}\text { rol de palavras antecipadamente. Elas } \\
\text { serão apresentadas uma a cada vez e } \\
\text { lhes será dado } 30 \text { segundos para } \\
\text { cada palavra. Cada folha deverá ter } \\
\text { uma marca que as distinga, mas que } \\
\text { não seja perceptivel para os } \\
\text { participantes, a fim de evitar outras } \\
\text { induções além da audição da palavra. } \\
\text { Este procedimento é necessário para } \\
\text { possibilitar a atividade } 2 \text {. }\end{array}$ \\
\hline $\begin{array}{l}\text { 2. Em grupo, reunir e identificar as } \\
\text { palavras associadas aos termos e } \\
\text { suas freqüências. Apresentar em } \\
\text { plenária }-30^{\prime}\end{array}$ & $\begin{array}{l}\text { 2. Dividir a turma em quatro grupos. } \\
\text { Cada um trabalhará a associação } \\
\text { feita em uma das palavras para } \\
\text { apresentar os resultados em plenária }\end{array}$ \\
\hline 3. Plenária. $-30^{\prime}$ & $\begin{array}{l}\text { Discutir as sobreposições de } \\
\text { representaçóes, salientando a } \\
\text { convenção em distinguir cada uma e } \\
\text { a especificidade da linguagem da } \\
\text { ética e do direito. }\end{array}$ \\
\hline 4. Aula síntese $-45^{\prime}$ & $\begin{array}{l}\text { 4. Destacar as convenções na } \\
\text { distinção de ética e moral, } \\
\text { esclarecendo a mais apropriada para } \\
\text { compreender e empregar a } \\
\text { deliberação moral. Enfatizar os niveis } \\
\text { do deve e do deveria. Apresentar a } \\
\text { bioética como nova forma de abordar } \\
\text { a ética em saúde, com } \\
\text { responsabilidade e prudência }\end{array}$ \\
\hline $\begin{array}{l}\text { 5. Aula expositivo-participativa sobre } \\
\text { o método da deliberação moral - } \\
\text { 1h45' }\end{array}$ & \\
\hline
\end{tabular}

Material preparado com finalidades didáticas. Exclusivo para uso no Curso de Atualização para Profissionais de Saúde na Atenção Básica - PMSA - Não autorizada reprodução ou uso do material para outras finalidades 


\section{Seqüência de atividades 3}

Objetivos: (a) Explicar os objetivos e procedimentos de cada etapa do método de deliberação (b) Utilizar o método da deliberação em um caso hipotético (c) Discutir a utilidade de técnicas de intermediação na aplicação do método de deliberação

(d) Instigar à percepção de que não existe somente uma decisão possível e/ou prudente para os problemas éticos

Conceito chave: Deliberação moral. Responsabilidade. Prudência.

\section{Conhecimentos:}

O método de deliberação e seus procedimentos

Os objetivos dos diferentes passos do método de deliberação

\begin{tabular}{|c|c|}
\hline PARTICIPANTE & MONITOR \\
\hline $\begin{array}{l}\text { 1. Momento inicial para discussão das } \\
\text { dúvidas ou outros pontos de interesse } \\
\text { acerca do método de deliberação } 15^{\prime}\end{array}$ & $\begin{array}{l}\text { 1. Retomar os pontos principais da } \\
\text { atividade } 5 \text { da seqüência } 2 \text { (aula } \\
\text { síntese sobre deliberação) Estimular } \\
\text { que alunos apresentem suas dúvidas } \\
\text { e considerações. }\end{array}$ \\
\hline $\begin{array}{l}\text { 2. Exercício de aplicação do método } \\
\text { de deliberação. Leia o caso a seguir e } \\
\text { aplique o método de deliberação. A } \\
\text { primeira fase - esclarecimento dos } \\
\text { fatos - será feita na plenária. As } \\
\text { demais em grupo, para depois } \\
\text { retomar a plenária 30' } \\
\text { O senhor M tem sífilis, ele não quer } \\
\text { contar o que tem para sua esposa, } \\
\text { mas quer protegê-la da doença. } \\
\text { Enquanto está em tratamento, pede } \\
\text { para que se faça o exame na sua }\end{array}$ & $\begin{array}{l}\text { 2. Dividir a turma em } 3 \text { grupos para a } \\
\text { atividade. Explicar como será a } \\
\text { atividade. Iniciar o exercício de } \\
\text { aplicação do método com a fase de } \\
\text { esclarecimento dos fatos. Estimular } \\
\text { que façam perguntas e entendam os } \\
\text { dados disponíveis sobre o caso, antes } \\
\text { de por em prática as fases seguintes }\end{array}$ \\
\hline
\end{tabular}

Material preparado com finalidades didáticas. Exclusivo para uso no Curso de Atualização para Profissionais de Saúde na Atenção Básica - PMSA - Não autorizada reprodução ou uso do material para outras finalidades 


\begin{tabular}{|l|l|}
\hline esposa sem que ela saiba de nada. & \\
\hline $\begin{array}{l}\text { 3. Em grupo, com apoio do de } \\
\text { material instrucional aplicar as fases } \\
\text { sucessivas do método de deliberação } \\
\text { 1h30' }\end{array}$ & $\begin{array}{l}\text { 3. Acompanhar os grupos na } \\
\text { deliberação, esclarecendo suas } \\
\text { dúvidas }\end{array}$ \\
\hline $\begin{array}{l}\text { 4. Plenária para apresentação do } \\
\text { caso. A apresentação será feita } \\
\text { segundo as fases do método. 1h }\end{array}$ & $\begin{array}{l}\text { 4. coordenar a plenária, simulando } \\
\text { uma sessão de deliberação. Um } \\
\text { grupo apresenta e os demais } \\
\text { complementam. }\end{array}$ \\
\hline $\begin{array}{l}\text { D. discussão das dúvidas na } \\
\text { aplicação do método 15' }\end{array}$ & $\begin{array}{l}5 . \text { Estimular que coloquem o que } \\
\text { sentiram e as dificuldades que tiveram } \\
\text { para a aplicação do método }\end{array}$ \\
\hline $\begin{array}{l}\text { 6. Orientações para as atividades de } \\
\text { dispersão 30' }\end{array}$ & $\begin{array}{l}\text { Exercício individual de aplicação do } \\
\text { método a casos hipotéticos. Este } \\
\text { exercício deverá ser entregue por } \\
\text { escrito no primeiro dia da segunda } \\
\text { semana de concentração. } \\
\text { Dividir a turma em trios, para a } \\
\text { sessões clínicas da segunda semana } \\
\text { de concentração. Dar as instruções } \\
\text { necessárias, explicando as funções } \\
\text { de quem apresenta o caso, do } \\
\text { coordenador da sessão e do } \\
\text { observador. Estimular que tragam } \\
\text { casos vividos (abertos ou encerrados) } \\
\text { para os quais gostariam da } \\
\text { contribuição da deliberação do grupo. }\end{array}$ \\
\hline
\end{tabular}




\section{Seqüência de atividades 4}

Objetivos: (a) Discutir as peculiaridades da relação profissional-usuário na atenção básica e as implicações para a bioética nesse nivel da assistência (b) Distinguir fatos e valores envolvidos na relaçăo clínica, com o apoio de uma situação comum da atençăo básica (c) Contribuir para o desenvolvimento das habilidades necessárias na aplicação do método de deliberaçăo

Conceito chave: Clínica ampliada. Ética na relação clinica

Conhecimentos:

Peculiaridades da relação clínica na atenção básica e a clínica ampliada

As implicaçōes da clínica ampliada para a bioética

Problemas éticos nas relações com os usuários e as famílias na atenção básica, segundo a visão dos enfermeiros e médicos

Contribuições de habilidades como as técnicas de entrevista clínica, relação de ajuda, suporte emocional, comunicaçăo terapêutica, etc para a melhoria da relação profissional-usuário

\begin{tabular}{|l|l|}
\hline \multicolumn{1}{|c|}{ PARTICIPANTE } & \multicolumn{1}{c|}{ MONITOR } \\
\hline 1.Ler o caso a seguir e discutir nos & 1. Dividir a turma em três grupos. \\
grupos: & $\begin{array}{l}\text { Acompanhar a discussão nos grupos, } \\
\text { - Paciente, cliente ou usuário: a quem } \\
\text { cuidando para que se centrem nas }\end{array}$ \\
que? A quem eu gostaria de atender? & do caso em si. O caso deve servir \\
Por que? 45' & apenas de estímulo à lembrança do \\
- A relação do profissional de saúde & cotidiano que vivem em sua prática \\
com o usuário na atenção básica & profissional na atenção básica. \\
diferencia-se do hospital? Por que? & \\
Em que? & \\
O senhor C, tem 55 anos, é & \\
hipertenso diabético, & \\
freqüentemente faz demandas que & \\
\hline
\end{tabular}

Materiał preparado com finalidades didáticas. Exclusivo para uso no Curso de Atualização para Profissionais de Saúde na Atenção Básica - PMSA - Não autorizada reproduçăo ou uso do material para outras finalidades 


\begin{tabular}{|c|c|}
\hline $\begin{array}{l}\text { dificultam as atividades e perturbam a } \\
\text { rotina da unidade de saúde. O médico } \\
\text { e a enfermeira tentam assisti-lo da } \\
\text { melhor maneira possivel, mas a cada } \\
\text { dia, sentem-se mais tentados a } \\
\text { desistir de investir seus esforços. }\end{array}$ & \\
\hline $\begin{array}{l}\text { 2. Em plenária discutir as } \\
\text { peculiaridades da relação clínica na } \\
\text { atenção básica, a partir da } \\
\text { apresentação das resposta a segunda } \\
\text { pergunta da atividade } 1 .\end{array}$ & $\begin{array}{l}\text { 2. Estimular que coloquem o que } \\
\text { sentem, especialmente em relação à } \\
\text { proximidade e duração da relação, e } \\
\text { maior independência do usuário }\end{array}$ \\
\hline $\begin{array}{l}\text { 3. Síntese da plenária: } \\
\text { ampliada e pistas para uma } \\
\text { comunicação mais fluida } 45^{\prime} \\
\text { (atividades } 2 \text { e } 3 \text { ) }\end{array}$ & $\begin{array}{l}\text { 3. De maneira esquemática, distinguir } \\
\text { a clínica na atenção básica da feita no } \\
\text { hospital e o que pode ou não ser útil, } \\
\text { na comunicação, para favorecer a } \\
\text { melhor relação clínica e manejo dos } \\
\text { conflitos éticos }\end{array}$ \\
\hline $\begin{array}{l}\text { 4. Em grupos, retomar o caso da } \\
\text { atividade } 1 \text { e identificar os fatos e os } \\
\text { valores envolvidos. Esta atividade } \\
\text { deverá ser entregue por escrito. Năo } \\
\text { haverá plenária 30' }\end{array}$ & $\begin{array}{l}\text { 4. Explicar que não é preciso chegar a } \\
\text { um consenso no grupo. Observar } \\
\text { como flui a comunicação, a escuta, a } \\
\text { tolerância a opiniōes distintas. } \\
\text { Estimular que estejam atentos aos } \\
\text { valores e não se fixem somente nos } \\
\text { fatos ou no dever de "não abandonar" } \\
\text { insinuado no caso. }\end{array}$ \\
\hline $\begin{array}{l}\text { 5. Leitura crítica do texto "Para uma } \\
\text { clínica ampliada, uma bioética } \\
\text { amplificada". Durante a leitura ir } \\
\text { contrastando o texto com as } \\
\text { discussões das atividades anteriores } \\
\text { e o caso da atividade } 1\end{array}$ & \\
\hline
\end{tabular}

Material preparado com finalidades didáticas. Exclusivo para uso no Curso de Atualizaçāo para Profissionais de Saúde na Atenção Básica - PMSA - Não autorizada reproduçăo ou uso do material para outras finalidades 


\begin{tabular}{|l|l|}
\hline $\begin{array}{l}\text { 6. Elaborar um parágrafo que sintetize } \\
\text { "É possivel justificar 'não abandonar o } \\
\text { senhor C'? Como?" } 1 \text { h45h (atividades } \\
5 \text { e 6) }\end{array}$ & \\
\hline $\begin{array}{l}\text { 7. Ler na plenária os parágrafos. } \\
\text { Participar do encerramento da }\end{array}$ & $\begin{array}{l}\text { 7. Sintetizar com base nos parágrafos } \\
\text { construidos pelos grupos. } \\
\text { atividade. } 15 \text { ' }\end{array}$ \\
\hline
\end{tabular}




\section{Seqüência de atividades 5}

Objetivos: (a) Discutir os conflitos nas relações de equipe como fonte de problemas éticos na atenção básica (b) Assinalar a importância de resolver de maneira argumentada os problemas éticos que surgem no trabalho em equipe (c) Propiciar a reflexão sobre a comunicação, a confiança e o respeito como valores para o trabalho em equipe (d) introduzir a concepção de comunicação assertiva como uma chave para melhorar as relaçōes de equipe

Conceito chave: $O$ trabalho em equipe. Ética nas relações de equipe

\section{Conhecimentos:}

Condições básicas para o bom andamento dos trabalhos de equipe

Os conflitos no trabalho em equipe na atençăo básica

Tipologia e motivos dos conflitos no trabalho em equipe

Gestão positiva e respeitosa dos conflitos nas relaçōes de equipe

Problemas éticos nas relações em equipe segundo a visão dos enfermeiros e médicos na atenção básica

Contribuição da comunicação assertiva para o manejo dos problemas éticos nas relações de trabalho

\begin{tabular}{|c|c|}
\hline TE & MONITOR \\
\hline $\begin{array}{l}\text { 1. Em grupo, leia o caso abaixo e } \\
\text { discuta como ocorrem: } \\
\text { a) a confiança mutua } \\
\text { b) a comunicação } \\
\text { c) o apoio mutuo e a cooperação } \\
\text { d) a compreensão e a identificação } \\
\text { com os objetivos da atenção básica e } \\
\text { da assistência à saúde } \\
\text { e) o tratamento das diferenças }\end{array}$ & $\begin{array}{l}\text { 1. Dividir a turma em três grupos para } \\
\text { desenvolvimento da seqüência de } \\
\text { atividades. } \\
\text { As atividades } 1,2 \text { e } 3 \text { não terão } \\
\text { plenária ou produto escrito. o } \\
\text { propósito é propiciar um espaço de } \\
\text { 'conversa dirigida' para que os } \\
\text { participantes possam compartilhar } \\
\text { suas vivências de trabalho em equipe. } \\
\text { Tempo para as atividades } 1,2,3-1 \\
\text { hora }\end{array}$ \\
\hline
\end{tabular}

Material preparado com finalidades didáticas. Exclusivo para uso no Curso de Atualizaçăo para Profissionais de Saúde na Atençăo Básica - PMSA - Não autorizada reprodução ou uso do material para outras finalidades 
Pilar "estava de responsável", naquele dia, pelos problemas que viessem a ocorrer na unidade. Na UBS Jardim Parla, havia uma escala e a cada dia uma enfermeira era "referência", ou seja, todos os problemas da unidade, no dia, "seriam responsabilidade" dessa enfermeira e não da diretora "diretamente", que também era uma enfermeira. Às 8 horas da manhã, chega na UBS Maicon, uma criança de aproximadamente seis anos de idade, com suspeita de rubéola. Maicon é avaliado pela enfermeira, que fica preocupada porque a UBS estava lotada de usuários, sendo boa parte deles crianças e gestantes. $A$ unidade também contava com um médico que era "referência" para os casos não agendados. $A$ cada dia, um dos médicos das equipes era designado para esta função, devendo atender os casos de todas as equipes a partir das 10 horas. Como ainda eram 8 horas e a unidade estava lotada, Pilar entende que a melhor conduta seria encaminhar a criança para consulta médica imediatamente, a fim de que sua permanência na unidade fosse a menor possivel, para não expor os susceptiveis, 


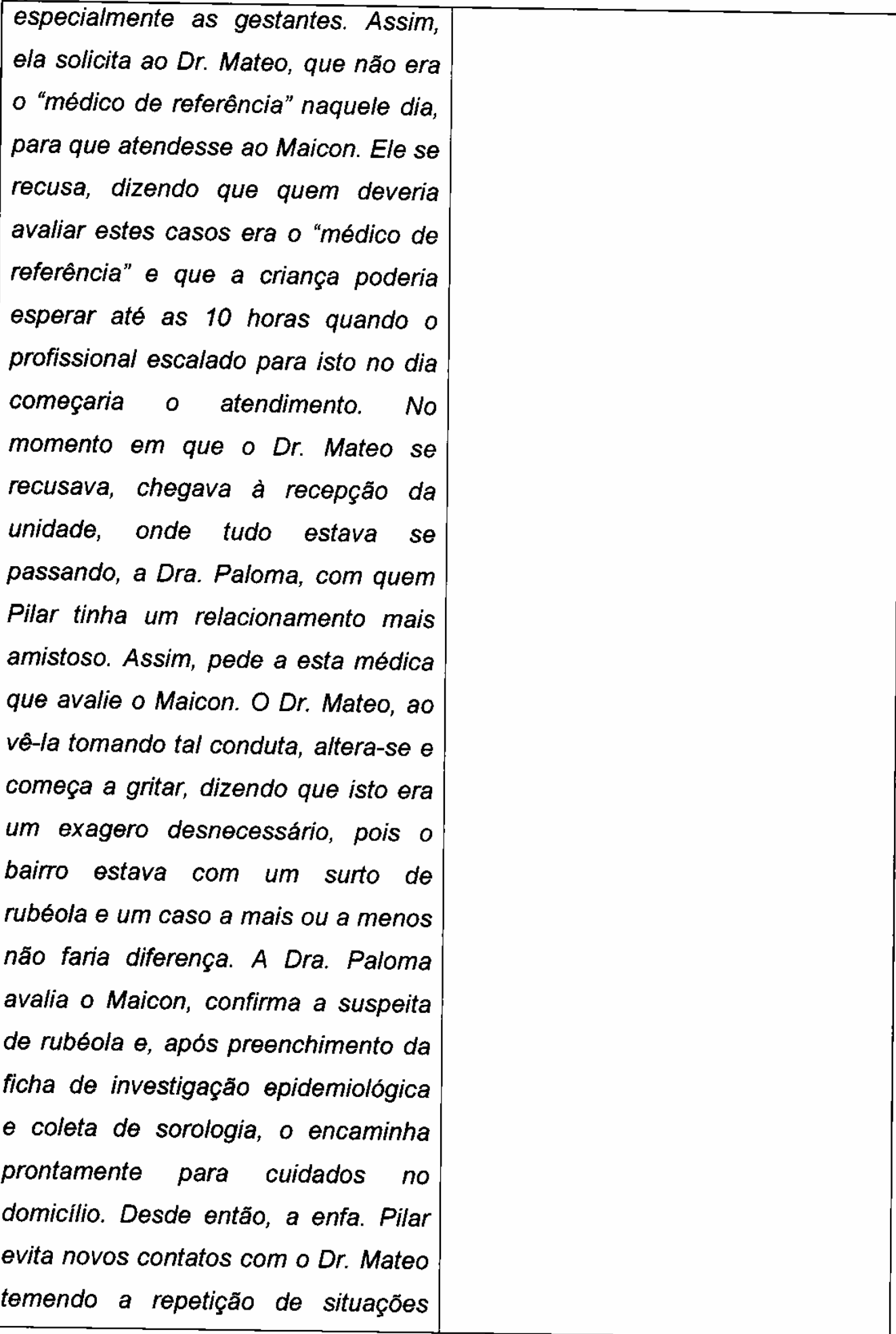

Material preparado com finatidades didáticas. Exclusivo para uso no Curso de Atualizaçăo para Profissionais de Saúde na Atençāo Básica - PMSA - Nāo autorizada reprodução ou uso do material para outras finalidades 


\begin{tabular}{|l|l|}
\hline similares. O ocorrido não chega ao \\
conhecimento da diretoria da unidade. & \\
\hline 2. Siga na análise do caso e examine & \\
os "sintomas gerais" do conflito de & \\
equipe: \\
a) ataque às idéias antes que hajam \\
sido expressadas \\
b) exposição violenta dos argumentos \\
c) clima de impaciência que guarda \\
uma agressividade contida \\
d) desconfiança na capacidade da \\
equipe, a ponto de falar mal da \\
própria equipe \\
e) acusações reciprocas \\
f) tensões polarizadas em lados \\
opostos que se negam a ceder \\
g) oposição sistemática às propostas \\
de qualquer dos membros da equipe, \\
de forma que não se chega a decisão \\
alguma
\end{tabular}

Material preparado com finalidades didáticas. Exclusivo para uso no Curso de Atualização para Profissionais de Saúde na Atenção Básica - PMSA - Não autorizada reprodução ou uso do material para outras finalidades 


\begin{tabular}{|c|c|}
\hline $\begin{array}{l}\text { e) competências e limites de cada } \\
\text { categoria profissional e a interface de } \\
\text { suas especificidades no trabalho em } \\
\text { equipe }\end{array}$ & \\
\hline $\begin{array}{l}\text { 4. Tendo em conta sua experiência de } \\
\text { trabalhos em equipe e considerando } \\
\text { as discussões das atividades } 1,2 \text { e } 3 \\
\text { faça o exercício: } \\
\text { O conflito não é sempre negativo, ele } \\
\text { também pode favorecer o crescimento } \\
\text { da equipe. Vocês já viveram situaçŏes } \\
\text { de conflito que tenham favorecido o } \\
\text { crescimento do grupo e de seus } \\
\text { integrantes? Que fatores contribuíram } \\
\text { para que isso? 30' }\end{array}$ & \\
\hline $\begin{array}{l}\text { 5. Apresente em plenária a atividade } \\
4 \\
45^{\prime}\end{array}$ & $\begin{array}{l}\text { 5. Destacar, durante a plenária, as } \\
\text { ferramentas úteis para a boa gestão } \\
\text { dos conflitos, enfatizando a } \\
\text { comunicação assertiva }\end{array}$ \\
\hline $\begin{array}{l}\text { 6. Participar da aula sintese: Valores } \\
\text { intrínsecos e extrinsecos no trabalho } \\
\text { em saúde } 45^{\prime}\end{array}$ & $\begin{array}{l}\text { 6. Enfatizar o bem interno das } \\
\text { profissões de saúde e como este } \\
\text { deve nortear o trabalho. }\end{array}$ \\
\hline $\begin{array}{l}\text { 7. Em grupo, com base nas } \\
\text { discussões e na aula síntese refaça } \\
\text { os fatos do caso da atividade } 1 \text {, } \\
\text { preparando uma dramatização de } 5 \\
\text { minutos. } \\
\text { Reconstrua a cena para que haja uma } \\
\text { comunicação fluida e relações de } \\
\text { respeito na equipe, de forma a } \\
\text { potencializar a atenção prestada ao }\end{array}$ & $\begin{array}{l}\text { 7. Dividir a turma em dois grupos para } \\
\text { reconstrução da cena do caso. } \\
\text { Estimular que tenham em vista no } \\
\text { preparo da dramatização o bem } \\
\text { interno da saúde e os valores da } \\
\text { atenção básica. }\end{array}$ \\
\hline
\end{tabular}

Material preparado com finalidades didáticas. Exclusivo para uso no Curso de Atualização para Profissionais de Saúde na Atenção Básica - PMSA - Nāo autorizada reprodução ou uso do material para outras finalidadẹ 


\begin{tabular}{|l|l|}
\hline Usuário. Considere o resultado & \\
esperado de cada um e do conjunto & \\
da equipe para garantir a qualidade & \\
do cuidado. & \\
Apresentar a dramatização para o & \\
restante da sala $45^{\prime}$ & \\
\hline 8 . Fechamento da semana 15 & \\
\hline
\end{tabular}

Materiat preparado com finalidades didáticas. Exclusivo para uso no Curso de Atualização para Profissionais de Saúde na Atenção Básica - PMSA - N5́o autorizada reproduçăo ou uso do material para outras finalidades 


\section{DELIBERAÇÃO MORAL \\ INSTRUÇÕES PARA A SEQUÊNCIA DE ATIVIDADES 3}

Este material é preparado a partir de algumas publicações ${ }^{i, i, 13,4}$, com a observação e anotações feitas em aula e que partilhamos no espaço virtual de ensino do Mestrado em Bioética. Destina-se exclusivamente ao uso didático.

A deliberação moral é um método, um procedimento com fases pelas quais tem de passar o processo deliberativo, a análise crítica do caso em uma sessão de deliberação que pode ter lugar, por exemplo, em comitês e comissões de bioética ou em reuniões das equipes de saúde. Os passos do método da deliberação, esquematicamente, são:

\begin{tabular}{|l|l|}
\hline Deliberação sobre os fatos & $\begin{array}{l}\text { 1.apresentação do caso } \\
\text { 2. esclarecimento dos fatos do caso }\end{array}$ \\
\hline Deliberação sobre valores & $\begin{array}{l}\text { 3. identificação dos problemas morais } \\
\text { do caso } \\
4 . \text { indicação do problema moral } \\
\text { fundamental } \\
5 . \text { identificação dos valores em } \\
\text { conflito }\end{array}$ \\
\hline Deliberação sobre os deveres & $\begin{array}{l}6 . \text { identificação dos cursos de ação } \\
\text { extremos } \\
7 . \text { identificação dos cursos de ação } \\
\text { intermédios } \\
8 . \text { identificação do curso de ação } \\
\text { ótimo }\end{array}$ \\
\hline Deliberação & as \\
responsabilidades & $\begin{array}{l}\text { aplicação das provas de } \\
\text { consistência ao curso de ação ótimo: } \\
\text { tempo, publicidade e legalidade } \\
10 . \text { decisão final }\end{array}$ \\
\hline
\end{tabular}

Material preparado com finalidades didáticas. Exclusivo para uso no Curso de Atualização para Profissionais de Saúde na Atenção Básica - PMSA - Não autorizada reprodução ou uso do material para outras finalidades 


\section{I) Deliberação sobre os fatos}

1. Apresentação do caso. É quando a pessoa responsável pelo caso apresenta-o, contando a história clínica, com ênfase para a questão e os aspectos éticos. Esta fase lembra muito uma sessão clínica, e ocorre de forma semelhante, mas o foco não está no problema clínico e sim no moral. Mas, é preciso explorar os fatos clínicos, a história clínica, pois estes são os suportes dos valores em conflito. A história clínica é o suporte documental do problema ético que vai ser analisado e por isso tem que ser bem conhecida. Além dos aspectos clínicos, como o foco é a questão moral, é recomendável acrescentar na apresentação aspectos relativos às condições sociais, familiares, culturais, educacionais, religiosas e outros pontos necessários para compreender e problematizar a situação em seus aspectos éticos. Em relação aos dados clínicos, exploram-se o diagnóstico (o que ocorre), o prognóstico (o que poderá ocorrer) e o tratamento (alternativas terapêuticas).

2. Esclarecimento dos fatos do caso. Após a apresentação, abre-se um espaço para perguntas que serão dirigidas pelos participantes da sessão de deliberação a quem apresenta o caso. Esta fase é fundamental. Se o caso não for bem entendido, os erros deste momento se arrastarão para as demais etapas, comprometendo o processo de deliberação. Nesse momento pede-se a quem apresentou o caso esclarecimento de tudo que não tenha ficado suficientemente claro, que não tenha sido compreendido. Também se pode perguntar por aspectos que não foram incluídos, tentando entender, inclusive, porque isso ocorreu. Da mesma forma que no passo anterior, não se deve ater aos fatos clínicos apenas. Não é para "julgar" o caso. O que se quer é entendê-lo da maneira mais clara possível, abranger de maneira compreensiva o que está acontecendo. O propósito é reduzir as áreas de incerteza do caso ao máximo permitido, segundo as peculiaridades da situação. Isto ajudará na exploração e identificação de recursos úteis para a proposição dos cursos de ação, potencializando-se, assim, a deliberação. 


\section{II) Deliberação sobre os valores}

3. Identificação dos problemas morais. Nesta fase, listam-se todos os problemas morais que os participantes percebam no caso. Em princípio, problema moral será tudo que for percebido como tal por alguém, ou seja, basta que pelo menos um do grupo considere algo como problema moral para que, em princípio, seja tomado como tal. O problema é sempre uma dificuldade, uma dúvida. Por isso, uma boa maneira de enunciar os problemas morais é por meio de perguntas, formuladas em linguagem precisa, clara e sem uso de jargões, por exemplo, a linguagem dos princípios da autonomia, beneficência, não maleficência ou justiça que é bem comum na bioética. $\mathrm{O}$ uso de jargões e a imprecisão na formulação dos problemas dificultarão encontrar os valores em conflito. Um exemplo de como formular uma 'pergunta-problema' seria: 'Até onde chega responsabilidade de um médico diante de um paciente que não quer que Ihe façam uma transfusão?'. Recomenda-se evitar questões binárias, que levem a respostas do tipo sim/não. No exemplo: 'O médico deve respeitar a decisão de um paciente que não quer receber transfusão?', ou 'É lícito respeitar a decisão de um paciente que não quer receber transfusão?' Diferentemente da primeira formulação, as respostas mais imediatas às estas são um 'Sim' ou um 'Não', o que dificulta perceber os valores em conflito. Também não se usam fórmulas do tipo 'é ético....', pois ética é uma disciplina, o indicado seria 'é correto/incorreto...'. As perguntas também tem de localizar uma pessoa numa situação, não podem ser 'genéricas', porque são as pessoas quem tem problemas. Quanto mais localizada e precisa for a pergunta, mais fácil será encontrar os valores em conflito e a resposta que buscamos na deliberação. Como problema moral é um conflito de valores, dos possíveis valores que pode estar se lesionando no caso, nem todas as 'perguntas-problema' listadas nesta etapa serão de fato problemas morais, pois algumas não corresponderão a conflitos de valores. Neste momento, isso não tem importância. Ao contrário, é útil que formulemos os problemas em geral para que os possíveis conflitos de valores emirjam da realidade do caso. 
4. Indicação do problema moral fundamental. Dentre os problemas identificados no passo anterior, elege-se o que será alvo de deliberação. Como não é possível analisar todos os problemas morais enumerados, o melhor é indicar um ou dois fundamentais para seguir a deliberação. Normalmente, quem indica $\circ$ problema fundamental é a pessoa que apresentou o caso para a discussão, mas podem ser usados outros critérios. A pessoa que apresenta o caso e/ou pediu a assessoria da sessão de deliberação pode, inclusive, propor o problema moral que a aflige se este não aparecer entre os listados pelo grupo. Por isso, é útil que identifiquemos mais de sete e menos de quatorze 'questões problemas', para não sermos nem muito reduzidos e tampouco repetitivos.

5. Identificação dos valores em conflito. Nesta etapa, ocorre a identificação dos valores que estão ameaçados de serem lesionados, no interior do problema moral escolhido como fundamental. Os valores são sempre positivos. Neste momento é que se verificará se o problema eleito corresponde, de fato, a um conflito de valores. Somente os conflitos de valores podem ser alvo da deliberação. Assim, se o problema escolhido não consistir em um conflito de valores, se não for possível encontrar os valores em choque no seu interior, será preciso voltar à lista de problemas do passo 3. Para identificar os valores em conflitos, é preciso colocarse no lugar de quem apresenta o caso, tentando ver o que a pessoa sente, vive, o conflito de valores que experimenta. Não se trata, especificamente, de ser empático ou simpático, mas de fazer um rápido "role playing" mental, interno, assumindo o papel de quem apresenta para entender seu conflito de valores. Por exemplo, se quem apresenta é uma enfermeira, tem que se tentar ver o problema sob a ótica desta profissional e sua profissão. Um conflito mal definido comprometerá todo o processo de deliberação, podendo levar à perda da essência do caso. Por isso, é indispensável usar uma linguagem bastante clara e precisa para identificar o conflito de valores. Requer-se atenção, pois os valores já implicam uma linguagem mais abstrata, mais propícia às imprecisões, pois não somos habituados a lidar com este tipo de expressão que extrapola o mundo dos fatos. A identificação dos valores trata de por a linguagem concreta dos problemas 
em termos mais abstratos, mas isso não significa perder a precisão. Também convém identificar dois valores em conflito, opostos, embora se reconheça que sempre há outros implicados. Por isso, às vezes, podem ser indicados quatro valores, dois em cada pólo, mas não será útil listar muitos porque isso levará à dispersão da discussão, dificultando a identificação dos cursos intermédios e do ótimo, que devem salvar, proteger, levar à realização de todos os valores identificados.

Esquematicamente teremos:

\begin{tabular}{|l|l|l|l|l|}
\hline Valor $\mathrm{Y}$ & $\rightarrow$ & Problema $\mathrm{X}$ & $\boldsymbol{\bullet}$ & Valor $\mathrm{Z}$ \\
\hline
\end{tabular}

\section{III) Deliberação sobre os deveres}

6. Identificação dos cursos de ação extremos. É a etapa de sugestões de alternativas de solução, dos cursos de ação, para o manejo do caso. O dever é sempre prático, se trata de deliberar sobre o que devemos fazer para realizar os valores, tentando buscar todas as saídas possíveis para, dentre estas, eleger a ótima, a que realiza todos os valores em conflito sem lesar nenhum. A ética não trata do bom, mas do melhor, da excelência. Um curso extremo é o que opta por um valor, realizando-o às custas de lesar totalmente o outro que estava ameaçado no conflito. É muito importante elucidar bem os dois cursos extremos, pois costumam ser os mais imprudentes, que devem ser evitados. Isso não é fácil, pois a tendência da mente humana é pender para os extremos, reduzindo problemas a dilemas e enxergando somente duas vias possíveis de solução.

7. Identificação dos cursos de ação intermédios. Nesta etapa, apontam-se os cursos de ação que se movem entre os dois pólos opostos, ou seja, partem dos cursos extremos em direção ao centro. É neste passo que fica patente a racionalidade problemática que embasa o método da deliberação, ou seja, o modo problemático de interpretar e lidar com os conflitos de valores que permite enxergar outras saídas além das extremas. Pensar em problemas lança-nos a isso, a projetar-se em direção ao futuro, à busca de uma resposta, uma solução. Essa etapa de operacionalização da racionalidade problemática é fundamental, pois manter um modo dilemático de pensar levará a enxergar apenas os cursos 
extremos, trágicos porque sempre lesam um ou outro valor. Um problema que é mal proposto pode se transformar num "pseudo-dilema", comprometendo o processo de deliberação. Por isso, há de se buscar mais de duas saídas para um problema moral, ou não se estará operando no modo de pensar problemático.

8. Identificação do curso de ação ótimo. É o momento de eleger o melhor curso de ação para resolver ou lidar com o caso. Lembre-se que um problema ético pode não ter solução, mas isso só poderá ser percebido ou concluído depois de percorrer o processo de deliberação. Esta oitava etapa é momento mais especificamente moral do método da deliberação, pois é quando se busca o ótimo, e a ética almeja o ótimo, não se contenta com o bom. O curso de ação ótimo é o que lesa, em menor grau, todos os valores em conflito. Ou seja, é o que salva mais, e ao máximo, os valores, ponderando as circunstâncias da situação e as conseqüências das decisões. Por isso, apresenta-se como uma alternativa prudente, responsável. O curso ótimo costuma ser o melhor dos cursos intermédios identificados, ou uma mescla destes. Escolher o curso ótimo não significa que, na prática, não poderão ocorrer falhas. Estas podem acontecer, por isso, é bom pensar, dentre os cursos intermédios propostos, uma sucessão de cursos a partir do 'ótimo', como numa árvore de decisão que indique a ordem em que os cursos ótimos serão percorridos em caso de falhas. Também é bom que se pense para qual extremo se tenderá, no caso de falharem todos os cursos intermédios. Por vezes, a solução extrema é necessária, mas como exceção, e somente depois de serem esgotados todos os cursos intermédios. E assim, mesmo recomenda-se voltar a analisar a situação, pois, muitas vezes, as circunstancias mudam tornando possível vislumbrar novos cursos intermédios. Os extremos são soluções extraordinárias.

9. Aplicação das provas de consistência. Consiste em submeter o curso de ação ótimo a uma comprovação de sua consistência por meio das provas: (a) Legalidade: essa decisão é legal?; (b) Publicidade: estaria disposto a defender publicamente a decisão tomada? e (c) Temporalidade: tomaria a mesma decisão 
se tivesse mais tempo para decidir?. Estes critérios de contraste visam garantir que a decisão que se vai tomar seja prudente e responsável. A prova do tempo, em um exercício mental, tenta assegurar que a decisão não seja precipitada, impulsiva, excessivamente movida pelas emoções, o que a enviesaria e impediria a prudência. A legalidade tenta evitar que se tomem decisões contra a lei. Note que é somente agora que se contrasta a decisão da deliberação moral com o direito, com a norma jurídica. Não se começa nunca por esse caminho. Assim não cabem perguntas-problema que indaguem pela legalidade de algum ato. No exemplo, dado, não caberia a perguntar: 'É legal não transfundir um paciente que precise do procedimento e que não o queira?' Pode haver cursos de ação que sejam éticos, mas não são legais. A prova da publicidade visa verificar se a decisão é passível de argumentação pública, sem gerar o sentimento de vergonha. A decisão prudente é a que passa nas três provas.

10. Decisão final. A decisão final é responsabilidade de quem apresenta o caso, de quem pediu a ajuda da instância de deliberação. Por isso, quem apresenta o caso deve ter um papel ativo durante a sessão de deliberação, pois esta é uma oportunidade rara de esclarecer dúvidas e enriquecer o momento da tomada de decisão por meio da contribuição de muitas visões. Também de compartilhar angústias e responsabilidade, aliviando a carga de desgaste e o sofrimento moral gerados nas situações de conflitos éticos, o que colabora para a melhoria da qualidade na assistência e no trabalho.

Durante toda a sessão de deliberação: mantenha-se em escuta atenta; esforce-se para compreender a situação, analisar os valores implicados, argumentar consistentemente sobre os cursos de ação intermédios e o ótimo; evite falar ou emitir comentários quando não tiver a palavra; evite conversas e discussões paralelas, é comum querer aliviar a tensão provocada por esse tipo de discussão com conversas paralelas. Cuidar para que a sessão não se disperse ou tumultue com estes últimos tipos de comportamentos é uma das funções do coordenador, que deve assegurar a palavra de todos que dela queiram fazer uso. A tolerância 
também é necessária, pois a opção escolhida pode não coincidir com que você escolheria na mesma situação. Isso, necessariamente, não quer dizer que uma opção esteja errada e a outra certa, e sim que pode haver mais de uma solução prudente para o mesmo caso. 


\section{Seqüência de atividades 4}

Objetivos: (a) Discutir as peculiaridades da relação profissional-usuário na atenção básica e as implicações para a bioética nesse nivel da assistência (b) Distinguir fatos e valores envolvidos na relaçăo clínica, com o apoio de uma situação comum da atençăo básica (c) Contribuir para o desenvolvimento das habilidades necessárias na aplicação do método de deliberaçăo

Conceito chave: Clínica ampliada. Ética na relação clinica

Conhecimentos:

Peculiaridades da relação clínica na atenção básica e a clínica ampliada

As implicaçōes da clínica ampliada para a bioética

Problemas éticos nas relações com os usuários e as famílias na atenção básica, segundo a visão dos enfermeiros e médicos

Contribuições de habilidades como as técnicas de entrevista clínica, relação de ajuda, suporte emocional, comunicação terapêutica, etc para a melhoria da relação profissional-usuário

\begin{tabular}{|l|l|}
\hline \multicolumn{1}{|c|}{ PARTICIPANTE } & \multicolumn{1}{c|}{ MONITOR } \\
\hline 1.Ler o caso a seguir e discutir nos & 1. Dividir a turma em três grupos. \\
grupos: & $\begin{array}{l}\text { Acompanhar a discussão nos grupos, } \\
\text { - Paciente, cliente ou usuário: a quem } \\
\text { cuidando para que se centrem nas }\end{array}$ \\
que? A quem eu gostaria de atender? & do caso em si. O caso deve servir \\
Por que? 45' & apenas de estímulo à lembrança do \\
- A relação do profissional de saúde & cotidiano que vivem em sua prática \\
com o usuário na atenção básica & profissional na atenção básica. \\
diferencia-se do hospital? Por que? & \\
Em que? & \\
O senhor C, tem 55 anos, é & \\
hipertenso diabético, & \\
freqüentemente faz demandas que & \\
\hline
\end{tabular}

Materiał preparado com finalidades didáticas. Exclusivo para uso no Curso de Atualização para Profissionais de Saúde na Atenção Básica - PMSA - Não autorizada reproduçăo ou uso do material para outras finalidades 


\begin{tabular}{|c|c|}
\hline $\begin{array}{l}\text { dificultam as atividades e perturbam a } \\
\text { rotina da unidade de saúde. O médico } \\
\text { e a enfermeira tentam assisti-lo da } \\
\text { melhor maneira possivel, mas a cada } \\
\text { dia, sentem-se mais tentados a } \\
\text { desistir de investir seus esforços. }\end{array}$ & \\
\hline $\begin{array}{l}\text { 2. Em plenária discutir as } \\
\text { peculiaridades da relação clínica na } \\
\text { atenção básica, a partir da } \\
\text { apresentação das resposta a segunda } \\
\text { pergunta da atividade } 1 .\end{array}$ & $\begin{array}{l}\text { 2. Estimular que coloquem o que } \\
\text { sentem, especialmente em relação à } \\
\text { proximidade e duração da relação, e } \\
\text { maior independência do usuário }\end{array}$ \\
\hline $\begin{array}{l}\text { 3. Síntese da plenária: } \\
\text { ampliada e pistas para uma } \\
\text { comunicação mais fluida } 45^{\prime} \\
\text { (atividades } 2 \text { e } 3 \text { ) }\end{array}$ & $\begin{array}{l}\text { 3. De maneira esquemática, distinguir } \\
\text { a clínica na atenção básica da feita no } \\
\text { hospital e o que pode ou não ser útil, } \\
\text { na comunicação, para favorecer a } \\
\text { melhor relação clínica e manejo dos } \\
\text { conflitos éticos }\end{array}$ \\
\hline $\begin{array}{l}\text { 4. Em grupos, retomar o caso da } \\
\text { atividade } 1 \text { e identificar os fatos e os } \\
\text { valores envolvidos. Esta atividade } \\
\text { deverá ser entregue por escrito. Năo } \\
\text { haverá plenária 30' }\end{array}$ & $\begin{array}{l}\text { 4. Explicar que não é preciso chegar a } \\
\text { um consenso no grupo. Observar } \\
\text { como flui a comunicação, a escuta, a } \\
\text { tolerância a opiniōes distintas. } \\
\text { Estimular que estejam atentos aos } \\
\text { valores e não se fixem somente nos } \\
\text { fatos ou no dever de "não abandonar" } \\
\text { insinuado no caso. }\end{array}$ \\
\hline $\begin{array}{l}\text { 5. Leitura crítica do texto "Para uma } \\
\text { clínica ampliada, uma bioética } \\
\text { amplificada". Durante a leitura ir } \\
\text { contrastando o texto com as } \\
\text { discussões das atividades anteriores } \\
\text { e o caso da atividade } 1\end{array}$ & \\
\hline
\end{tabular}

Material preparado com finalidades didáticas. Exclusivo para uso no Curso de Atualizaçāo para Profissionais de Saúde na Atenção Básica - PMSA - Não autorizada reproduçăo ou uso do material para outras finalidades 


\begin{tabular}{|l|l|}
\hline $\begin{array}{l}\text { 6. Elaborar um parágrafo que sintetize } \\
\text { "É possivel justificar 'não abandonar o }\end{array}$ & 6. Recolher o produto da atividade \\
senhor C'? Como?" 1h45h (atividades & \\
5 e 6) & \\
\hline $\begin{array}{l}\text { 7. Ler na plenária os parágrafos. } \\
\text { Participar do encerramento da }\end{array}$ & $\begin{array}{l}\text { 7. Sintetizar com base nos parágrafos } \\
\text { construidos pelos grupos. } \\
\text { atividade. 15' }\end{array}$ \\
\hline
\end{tabular}




\section{Seqüência de atividades 5}

Objetivos: (a) Discutir os conflitos nas relações de equipe como fonte de problemas éticos na atenção básica (b) Assinalar a importância de resolver de maneira argumentada os problemas éticos que surgem no trabalho em equipe (c) Propiciar a reflexão sobre a comunicação, a confiança e o respeito como valores para o trabalho em equipe (d) introduzir a concepção de comunicação assertiva como uma chave para melhorar as relações de equipe

Conceito chave: $O$ trabalho em equipe. Ética nas relações de equipe Conhecimentos:

Condiçōes básicas para o bom andamento dos trabalhos de equipe

Os conflitos no trabalho em equipe na atenção básica

Tipologia e motivos dos conflitos no trabalho em equipe

Gestão positiva e respeitosa dos conflitos nas relaçōes de equipe

Problemas éticos nas relações em equipe segundo a vișăo dos enfermeiros e médicos na atenção básica

Contribuição da comunicação assertiva para o manejo dos problemas éticos nas relações de trabalho

\begin{tabular}{|c|c|}
\hline ANTE & MONITOR \\
\hline $\begin{array}{l}\text { 1. Em grupo, leia o caso abaixo e } \\
\text { discuta como ocorrem: } \\
\text { a) a confiança mutua } \\
\text { b) a comunicação } \\
\text { c) o apoio mutuo e a cooperação } \\
\text { d) a compreensão e a identificação } \\
\text { com os objetivos da atenção básica e } \\
\text { da assistência à saúde } \\
\text { e) o tratamento das diferenças }\end{array}$ & $\begin{array}{l}\text { 1. Dividir a turma em três grupos para } \\
\text { desenvolvimento da seqüência de } \\
\text { atividades. } \\
\text { As atividades } 1,2 \text { e } 3 \text { não terão } \\
\text { plenária ou produto escrito. o } \\
\text { propósito é propiciar um espaço de } \\
\text { 'conversa dirigida' para que os } \\
\text { participantes possam compartilhar } \\
\text { suas vivências de trabalho em equipe. } \\
\text { Tempo para as atividades } 1,2,3-1 \\
\text { hora }\end{array}$ \\
\hline
\end{tabular}

Material preparado com finalidades didáticas. Exclusivo para uso no Curso de Atualizaçăo para Profissionais de Saúde na Atençăo Básica - PMSA - Năo autorizada reproduçäo ou uso do material para outras finalidades 
Pilar "estava de responsável", naquele dia, pelos problemas que viessem a ocorrer na unidade. Na UBS Jardim Parla, havia uma escala e a cada dia uma enfermeira era "referência", ou seja, todos os problemas da unidade, no dia, "seriam responsabilidade" dessa enfermeira e não da diretora "diretamente", que também era uma enfermeira. Às 8 horas da manhã, chega na UBS Maicon, uma criança de aproximadamente seis anos de idade, com suspeita de rubéola. Maicon é avaliado pela enfermeira, que fica preocupada porque a UBS estava lotada de usuários, sendo boa parte deles crianças e gestantes. $A$ unidade também contava com um médico que era "referência" para os casos não agendados. $A$ cada dia, um dos médicos das equipes era designado para esta função, devendo atender os casos de todas as equipes a partir das 10 horas. Como ainda eram 8 horas e a unidade estava lotada, Pilar entende que a melhor conduta seria encaminhar a criança para consulta médica imediatamente, a fim de que sua permanência na unidade fosse a menor possivel, para não expor os susceptiveis, 


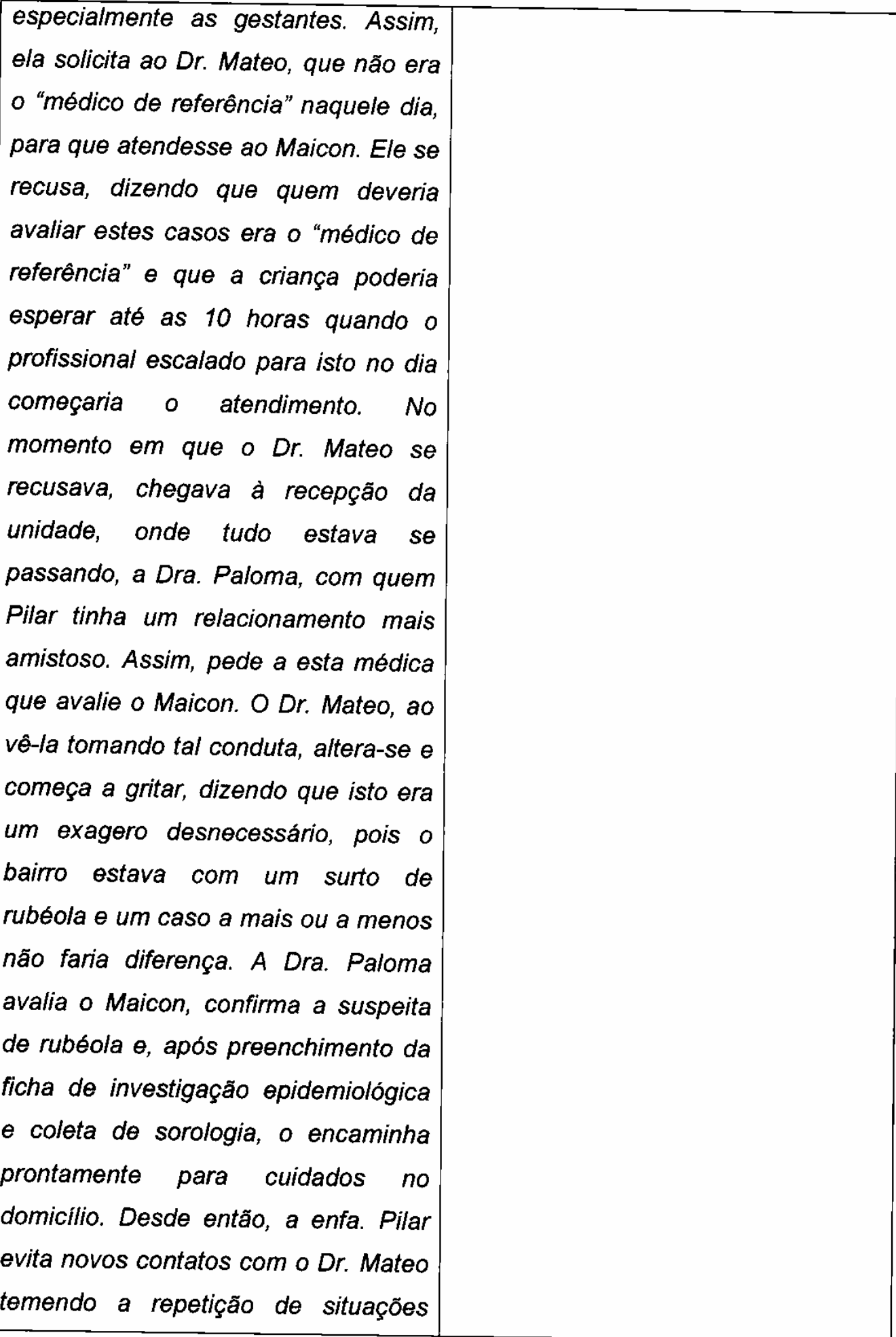

Material preparado com finatidades didáticas. Exclusivo para uso no Curso de Atualizaçăo para Profissionais de Saúde na Atençāo Básica - PMSA - Não autorizada reproduçăo ou uso do material para outras finalidades 
similares. O ocorrido não chega ao conhecimento da diretoria da unidade.

2. Siga na análise do caso e examine os "sintomas gerais" do conflito de equipe:

a) ataque às idéias antes que hajam sido expressadas

b) exposição violenta dos argumentos

c) clima de impaciência que guarda uma agressividade contida

d) desconfiança na capacidade da equipe, a ponto de falar mal da própria equipe

e) acusações reciprocas

f) tensões polarizadas em lados opostos que se negam a ceder

g) oposição sistemática às propostas de qualquer dos membros da equipe, de forma que não se chega a decisão alguma

3. Identificados os sintomas, quais seriam as motivações? Explore, ao menos, os seguintes aspectos:

a) visões quanto às finalidades do trabalho

b) valores éticos e visões de mundo

c) relações de poder, segurança e sentimentos de ameaça

d) carga de trabalho e outros fatores relacionados, como os recursos materiais disponiveis, etc. 


\begin{tabular}{|c|c|}
\hline $\begin{array}{l}\text { e) competências e limites de cada } \\
\text { categoria profissional e a interface de } \\
\text { suas especificidades no trabalho em } \\
\text { equipe }\end{array}$ & \\
\hline $\begin{array}{l}\text { 4. Tendo em conta sua experiência de } \\
\text { trabalhos em equipe e considerando } \\
\text { as discussôes das atividades } 1,2 \text { e } 3 \\
\text { faça o exercicio: } \\
\text { O conflito não é sempre negativo, ele } \\
\text { também pode favorecer o crescimento } \\
\text { da equipe. Vocês já viveram situaçöes } \\
\text { de conflito que tenham favorecido o } \\
\text { crescimento do grupo e de seus } \\
\text { integrantes? Que fatores contribuíram } \\
\text { para que isso? } 30^{\prime}\end{array}$ & \\
\hline $\begin{array}{l}\text { 5. Apresente em plenária a atividade } \\
4 \\
45^{\prime}\end{array}$ & $\begin{array}{l}\text { 5. Destacar, durante a plenária, as } \\
\text { ferramentas úteis para a boa gestão } \\
\text { dos conflitos, enfatizando a } \\
\text { comunicação assertiva }\end{array}$ \\
\hline $\begin{array}{l}\text { 6. Participar da aula sintese: Valores } \\
\text { intrínsecos e extrinsecos no trabalho } \\
\text { em saúde } 45^{\prime}\end{array}$ & $\begin{array}{l}\text { 6. Enfatizar o bem interno das } \\
\text { profissões de saúde e como este } \\
\text { deve nortear o trabalho. }\end{array}$ \\
\hline $\begin{array}{l}\text { 7. Em grupo, com base nas } \\
\text { discussões e na aula síntese refaça } \\
\text { os fatos do caso da atividade } 1, \\
\text { preparando uma dramatização de } 5 \\
\text { minutos. } \\
\text { Reconstrua a cena para que haja uma } \\
\text { comunicaçăo fluida e relações de } \\
\text { respeito na equipe, de forma a } \\
\text { potencializar a atenção prestada ao }\end{array}$ & $\begin{array}{l}\text { 7. Dividir a turma em dois grupos para } \\
\text { reconstrução da cena do caso. } \\
\text { Estimular que tenham em vista no } \\
\text { preparo da dramatização o bem } \\
\text { interno da saúde e os valores da } \\
\text { atenção básica. }\end{array}$ \\
\hline
\end{tabular}

Material preparado com finalidades didáticas. Exclusivo para uso no Curso de Atualização para Profissionais de Saúde na Atenção Básica - PMSA - Nāo autorizada reprodução ou uso do material para outras finalidadẹ 


\begin{tabular}{|l|l|}
\hline usuário. Considere o resultado & \\
esperado de cada um e do conjunto & \\
da equipe para garantir a qualidade & \\
do cuidado. \\
Apresentar a dramatização para o \\
restante da sala 45' & \\
\hline 8. Fechamento da semana 15' & \\
\hline
\end{tabular}

Materiat preparado com finalidades didáticas. Exclusivo para uso no Curso de Atualização para Profissionais de Saúde na Atenção Básica - PMSA - N5́o autorizada reproduçăo ou uso do material para outras finalidades 


\section{INSTRUÇÕES PARA AS ATIVIDADES DA SEMANA DE DISPERSÃO}

\section{Atividade 1: exercício individual de aplicação do método de deliberação}

Esta atividade é individual e deverá ser entregue por escrito no primeiro dia da segunda semana de concentração. Visa praticar as habilidades necessárias ao método da deliberação, levando a que cada um perceba suas dificuldades e onde deve investir esforços, bem como suas facilidades e onde pode contribuir de maneira mais efetiva para o trabalho grupal, na deliberação.

» Aplicar o método de deliberação ao caso que segue, adaptado do dilema de Heinz, do Teste de Desenvolvimento Moral de Kohlberg

"Percorrer cada uma das etapas do método de deliberaçăo, segundo o esquema utilizado nas atividades da semana de concentração, até chegar no curso de ação ótimo.

»Entregar o exercício, com as etapas: apresentação do caso; lista de problemas éticos, eleição do problema; valores em conflito; .cursos de ação extremos; cursos de ação intermédios; curso de açăo ótimo, decisão final "Se quiser, ao final, pode indicar qual delas foi mais fácil e/ou mais difícil de percorrer, apontando os motivos disso.

\section{Dilema de Heinz}

Em uma cidade, havia uma senhora que estava para morrer por causa de um tipo muito raro de câncer. Segundo a equipe médica que a assistia, havia um novo remédio que poderia salvá-la. Era uma nova fórmula de quimioterápico que acabava de ser desenvolvida por um farmacêutico da cidade. $O$ custo para a produção do remédio era muito alto. $E$ seu preço de final de venda, ficava ainda mais caro, porque, sobre o custo real de produção, o farmacéutico cobrava dez vezes mais. Ou seja, para prepará-lo o farmacêutico gastava $\$ 200.000$, mas vendia o medicamento por $\$ 2.200 .000$. Heinz, o marido da senhora doente, pediu dinheiro emprestado a todos os amigos, mas só conseguiu $\$ 1.100 .000$, a metade do preço do remédio. O gerente do banco negou-lhe empréstimo para o que faltava, pois Heinz não atendia as exigências 
para isso. Como o medicamento era muito novo, o sistema de saúde não podia fornecê-lo. Procurou o farmacêutico, explicou-lhe a situação e pediu-lhe que ou the vendesse o quimioterápico por um preço mais barato, ou que aceitasse receber os outros $50 \%$ mais tarde ou ainda em "parcelas". Mas, o farmacêutico Ihe responde: "Não! Eu descobri este remédio e quero ganhar dinheiro por isso!". Durante a noite, Heinz, furioso e preocupado por sua família, assalta a farmácia e rouba o medicamento para sua mulher que estava à morte e não podia mais esperar. Segundo os médicos, seu estado era gravissimo, pois todos os tratamentos mais conhecidos tinham falhado e se ela não recebesse o novo medicamento imediatamente morreria em alguns poucos dias, ou talvez horas.

\section{Atividade 2: em trios, preparar um caso para ser apresentado nas} sessōes de deliberação da segunda semana de concentração

Na segunda semana de concentraçăo, ocorrerão cinco sessōes de deliberação moral, com a apresentação de um caso a cada dia. Isto é, cada dia um trio apresentará o caso que preparou.

1) As sessōes terão duração de duas horas.

2) Escolher um caso que tenha sido vivido na prática em atenção básica, seja atual ou passado.

3) Preparar o caso para a apresentação coletando o máximo de informações que tiver disponivel. Uma das pessoas do trio ficará a cargo desta parte, desempenhará o papel de "proponente" ou "responsável" do caso. Recomenda-se que seja a pessoa que conhece melhor o caso, a situação.

4) Em sala, no momento da apresentação deverá ser feito um resumo do caso em exposição oral. Estarẫo disponíveis recursos áudio visuais, caso o grupo os deseje usar. Se tratar de caso encerrado, ou seja, já solucionado na prática, neste momento da apresentaçăo năo incluir o que foi feito, como foi resolvido, pois isto poderá induzir e invalidar a sessão de deliberação. 
5) Preparar um pequeno resumo da história clinica e outros dados que julgarem necessários para a análise e deliberaçăo do caso. Entregar a cada participante uma cópia deste resumo no início da sessão.

6) No transcurso da sessăo se apresentarão os problemas éticos, se identificarăo os valores em conflito e os cursos de ação, conforme as etapas do método de deliberação. $O$ trio terá de escolher uma das pessoas para coordenar a sessão. Esta terá de: cuidar para que se percorra todas as etapas; fazer a gestăo do tempo para não se detenha demais em uma etapa com prejuizo das subseqüentes por falta de tempo; garantir que se passe à deliberação de valores somente depois de ter deliberação dos fatos suficientemente esclarecida; assegurar a palavra a todos; estar atento para que não se perder os propósitos e metas de cada etapa.

7) O responsável pelo caso irá anotando, durante a sessão, a lista de problemas éticos, o problema ético escolhido, os cursos de ação. Haverá material para que isto seja feito de maneira que todos possam acompanhar (quadro ou fleep chart ou computador com projeção)

8) O terceiro participante do trio, atuará como observador. Assim, não participará ativamente da deliberaçăo, mas estará atento a todo andamento da sessăo, avaliando ao final se o procedimento foi aplicado de maneira adequada ou năo, quais os pontos fortes e fracos, se a gestão do tempo foi eficiente, se todos puderam participar, e como o grupo esteve durante a deliberação. Sua apreciação será compartilhada com o grupo, ao final da sessăo.

\footnotetext{
'Gracia D. La deliberación moral: el método de la ética clínica. Med Clin (Barc) 2001; 117: 18-23

"Gracia D. Moral deliberation: the role of methodologies in clinical ethics. Medicine, Health Care and Philosophy. 2001; 4: 223-232.
} 


\section{Anexo C}

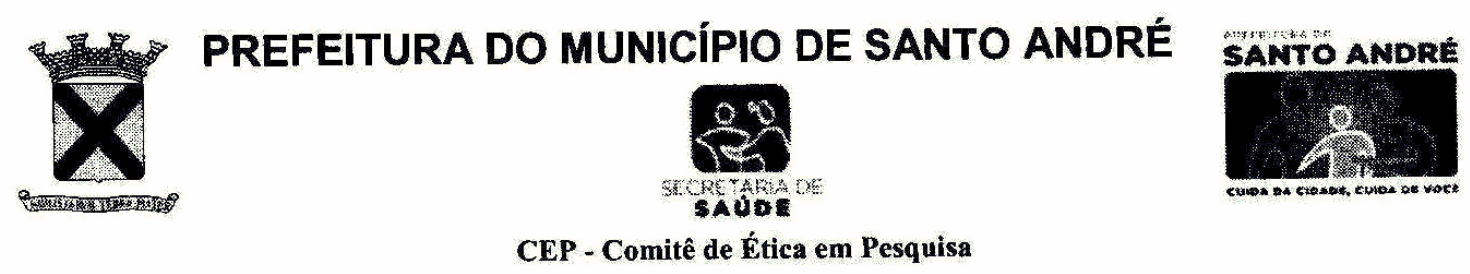

PROTOCOLO CEPSS-SA, REGISTRADO SOB O N". 008 /2010

Ilmo(a). Sr(a).

\section{Fátima Aparecida Cotrim Soares}

Prezado (a) Senhor (a):

Projeto de Pesquisa Intitulado: "Influência da Capacitação em Bioética na Percepção dos Profissionais para os Problemas Éticos na Atenção Básica"

Vimos por meio desta, informar que em reunião do Comitê de Ética em Pesquisa da Secretaria de Saúde de Santo André, realizada em 16/06/2010, foi aprovado o protocolo de pesquisa acima mencionado.

O Comitê de Ética em Pesquisa da Secretaria de Saúde de Santo André, em obediência à Resolução 196/96, deverá encaminhar a CONEP/MS, relatórios semestrais dos projetos de pesquisa que encontram-se em andamento. Solicitamos informar sobre o andamento do seu projeto anualmente isto é, se já foi concluído, suspenso ou se ainda está em andamento: neste último caso comunicar qual o tempo previsto para a conclusão do mesmo, e encaminhar breve resumo dos resultados obtidos no estudo.

Sem mais para o momento, subscrevemo-nos com os protestos de estima e consideração.

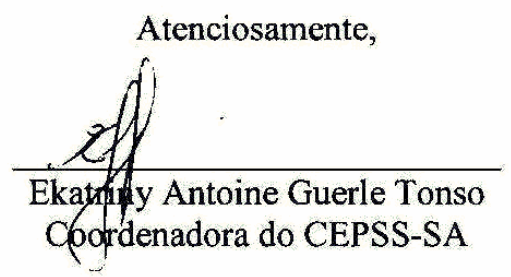

Praça do Carmo, $n^{\circ} 14$ - Centro - Santo André - SP

Fone: $4432-3446$ - 4432-3463

msautsumi@asantoandre.sp.gov.br 


\section{Anexo D}

\section{TERMO DE CONSENTIMENTO LIVRE E ESCLARECIDO}

Estamos realizando pela Escola de Enfermagem da Universidade de São Paulo, a pesquisa de mestrado "Influência da capacitação em bioética na percepção dos profissionais para os problemas éticos na atenção básica", com objetivo de identificar se os problemas éticos na atenção básica são percebidos pelos profissionais de saúde e se a participação em um curso de capacitação em bioética clínica e deliberação moral modifica a percepção que tem acerca dos problemas éticos na atenção básica. Esclareço que será convidado a participar de um curso de deliberação moral com carga horária de 40 horas, a ser realizado em equipamento da Prefeitura de Santo André. O curso será certificado pela Universidade de São Paulo (USP). Informo haverá liberação por parte da miunicipalidade para realização do curso. Assim por meio deste documento solicito o seu consentimento para participação respondendo a um questionário autoaplicado de 40 questões em que lhe será apresentado um problema ético e você responderá se não considera o exemplo como problema ético, ou se considera um problema um problema ético e o encontra em seu trabalho nunca, ocasionalmente ou comumente. Esclareço que poderá pedir maiores informações respeito da pesquisa a qualquer momento e que tem todo direito de se recusar a participar da pesquisa, inclusive podendo abandoná-la quando desejar sem que isto lhe traga prejuízos de qualquer espécie. Não será necessário que se identifique, sendo assim será mantido o anonimato dos participantes. Os dados obtidos serão utilizados pelas pesquisadoras somente para propósitos da pesquisa.

Se desejar esclarecimentos sobre a pesquisa, pode contatar as pesquisadoras pelos telefones 72512323 ou 30617652 .

Agradecemos sua atenção

Fátima aparecida Cotrim Soares Mestranda da EEUSP
Elma Lourdes Campos Pavone Zoboli

Professora Doutora da EEUSP - orientadora

$\mathrm{Eu}$, , declaro que estou de acordo em participar da pesquisa sobre a "Influência da capacitação em bioética na percepção dos profissionais para os problemas éticos na atenção básica”.

Assinatura do participante 